\title{
Subsurface Hybrid Power Options for Oil \& Gas Production at Deep Ocean Sites
}

J. C. Farmer, R. Haut, G. Jahn, J. Goldman, J. Colvin, A. Karpinski, A. Dobley, J. Halfinger, S. Nagley, K. Wolf, A. Shapiro, P. Doucette, P. Hansen, A. Oke, D. Compton, M. Cobb, R. Kopps, J. Chitwood, W. Spence, P. Remacle, C. Noel, J. Vicic, R. Dee

February 26, 2010 
This document was prepared as an account of work sponsored by an agency of the United States government. Neither the United States government nor Lawrence Livermore National Security, LLC, nor any of their employees makes any warranty, expressed or implied, or assumes any legal liability or responsibility for the accuracy, completeness, or usefulness of any information, apparatus, product, or process disclosed, or represents that its use would not infringe privately owned rights. Reference herein to any specific commercial product, process, or service by trade name, trademark, manufacturer, or otherwise does not necessarily constitute or imply its endorsement, recommendation, or favoring by the United States government or Lawrence Livermore National Security, LLC. The views and opinions of authors expressed herein do not necessarily state or reflect those of the United States government or Lawrence Livermore National Security, LLC, and shall not be used for advertising or product endorsement purposes.

This work performed under the auspices of the U.S. Department of Energy by Lawrence Livermore National Laboratory under Contract DE-AC52-07NA27344. 


\section{Subsurface Hybrid Power Options for Oil \& Gas Production at Deep Ocean Sites}

Joseph Farmer1, Richard Haut2, Ginny Jahn², John Goldman², John Colvin², Alexander Karpinski ${ }^{3}$, Arthur Dobley ${ }^{3}$, Jeff Halfinger ${ }^{4}$, Scott Nagley ${ }^{4}$, Kevin Wolf ${ }^{5}$, Andrew Shapiro6, Paul Doucette, Paul Hansen 7 , Akinsowon Oke ${ }^{7}$, Dewey Compton 7 , Michelle Cobb ${ }^{7}$, Richard Kopps ${ }^{7}$, Jim Chitwood 7 , Wayne Spence ${ }^{8}$, Philippe Remacle ${ }^{9}$, Cornelia Noel10, John Vicic ${ }^{10}$ and Ron Dee ${ }^{10}$

${ }^{1}$ Lawrence Livermore National Laboratory, ${ }^{2}$ Houston Advaced Research Center, ${ }^{3}$ Yardney Technical Products, ${ }^{4}$ Babcock \& Wilcox, ${ }^{5}$ Naval Facilities Engineering Service Center, ${ }^{6}$ General Electric Global Research, ${ }^{7}$ Chevron Energy Technology Company, ${ }^{8}$ CurtissWright Electro-Mechanical Corporation, ${ }^{9}$ Total Exploration \& Production USA LLC, ${ }^{10}$ Shell Oil Company 


\section{Table of Contents}

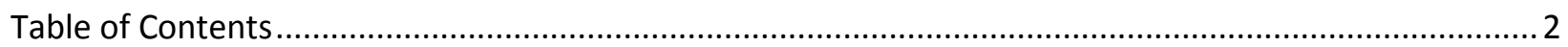

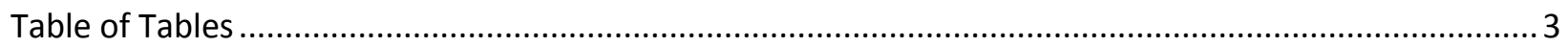

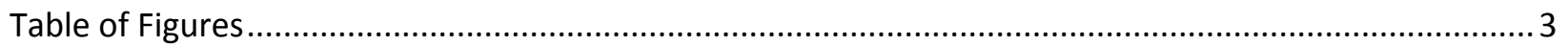

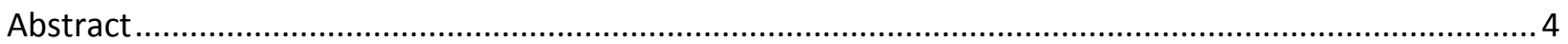

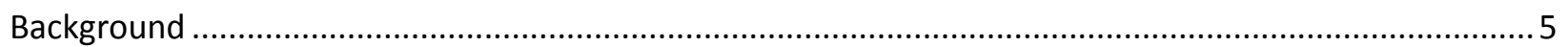

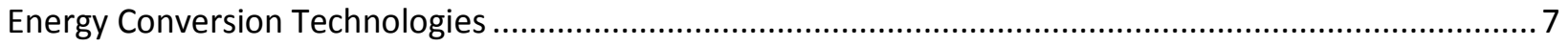

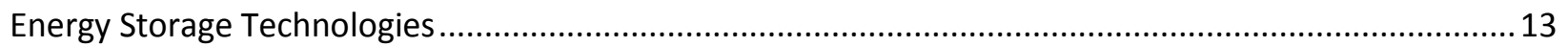

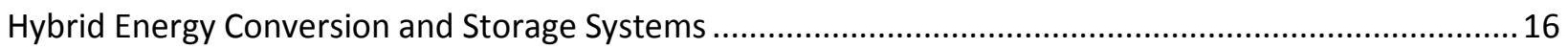

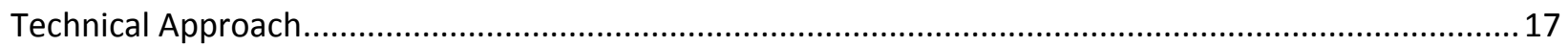

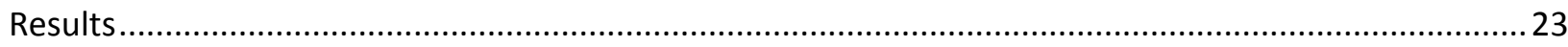

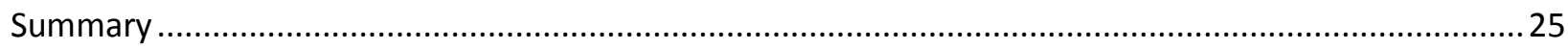

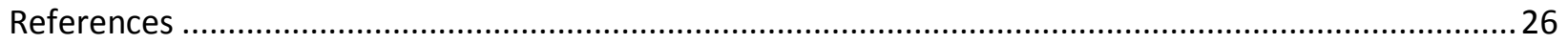

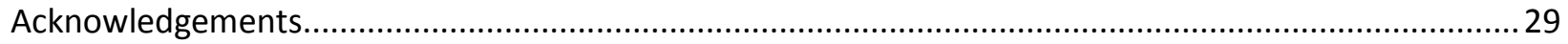

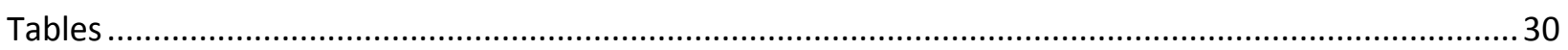

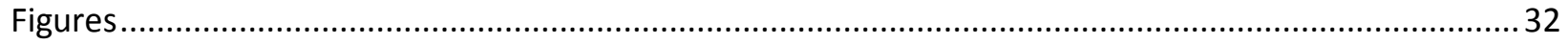

Appendix A - Background on World-Wide Use of Large and Modular Nuclear Reactors ...........................36

Appendix B - Representative Composition and Properties for Oil and Gas from Well Head ................... 41

Appendix C - Deep Ocean Experience with PEMFC Systems .............................................................. 39

Appendix D - Classes of Thermoelectric Materials and Devices ........................................................... 45

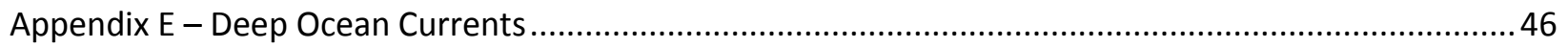

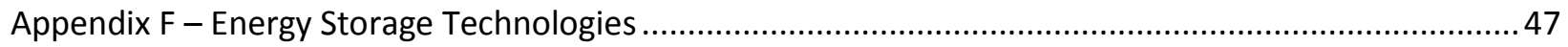

Appendix G - Tradeoff Between Specific Energy \& Specific Power .......................................................5 50

Appendix $\mathrm{H}$ - Summary of Assumptions Underlying Economic Analysis .................................................51

Appendix I - Detailed Analyses of Costs for Each Concept of Operations Site ..........................................5 54 


\section{Table of Tables}

Table 1 - Concept-of-operations sites for evaluation of deep ocean hybrid power systems 30

Table 2 - Summary of deep ocean hybrid generation and storage options considered for study ............ 30

Table 3 - Summary of attributes of power generation options used to assess hybrid system options .... 30

Table 4 - Summary of key attributes of energy storage options used to assess hybrid system options... 30

Table 5 - Summary of the predicted mass and volume of deep ocean hybrid power generation and energy storage options, for each of the con-ops cases

Table 6 - Summary of the cost-of-electricity, annualized costs and capital investment for each of the deep ocean hybrid power generation and energy storage options, for each of the con-ops cases

\section{Table of Figures}

Figure 1-Graphical comparison of the predicted masses of power generation and energy storage components, for each of the deep ocean hybrid systems, and for each of the con-ops cases.

Figure 3-Graphical comparison of the predicted volumes of the deep ocean hybrid power generation and energy storage options, for each of the RPSEA con-ops cases.

Figure 4-Graphical comparison of the predicted capital investment required for each deep ocean hybrid power generation and energy storage option, for each of the con-ops cases

Figure 5-Graphical comparison of the predicted annualized costs for each deep ocean hybrid power generation and energy storage option, for each of the RPSEA con-ops cases

Figure $6-$ Graphical comparison of the predicted cost-of-electricity produced by each of the deep ocean hybrid power generation and energy storage systems, at each of the con-ops sites

Figure 7 - The cost of electricity shows a very clear economy of scale, with the lowest electricity costs being realized for the largest sites 


\section{Subsurface Hybrid Power Options for Oil \& Gas Production at Deep Ocean Sites}

Joseph Farmer1, Richard Haut2, Ginny Jahn², John Goldman², John Colvin², Alexander Karpinski ${ }^{3}$, Arthur Dobley ${ }^{3}$, Jeff Halfinger ${ }^{4}$, Scott Nagley ${ }^{4}$, Kevin Wolf ${ }^{5}$, Andrew Shapiro 6 , Paul Doucette, Paul Hansen 7, Akinsowon Oke , Dewey Compton 7 , Michelle Cobb ${ }^{7}$, Richard Kopps 7 , Jim Chitwood 7 , Wayne Spence ${ }^{8}$, Philippe Remacle ${ }^{9}$, Cornelia Noel10, John Vicic ${ }^{10}$ and Ron Dee ${ }^{10}$

${ }^{1}$ Lawrence Livermore National Laboratory, ${ }^{2}$ Houston Advaced Research Center, ${ }^{3}$ Yardney Technical Products, ${ }^{4}$ Babcock \& Wilcox, ${ }^{5}$ Naval Facilities Engineering Service Center, ${ }^{6}$ General Electric Global Research, ${ }^{7}$ Chevron Energy Technology Company, ${ }^{8}$ CurtissWright Electro-Mechanical Corporation, ${ }^{9}$ Total Exploration \& Production USA LLC, 10Shell Oil Company
Abstract
An investment in deep-sea (deep-ocean) hybrid power systems may enable certain off-shore oil and gas exploration and production. Advanced deep-ocean drilling and production operations, locally powered, may provide commercial access to oil and gas reserves otherwise inaccessible. Further, subsea generation of electrical power has the potential of featuring a low carbon output resulting in improved environmental conditions. Such technology therefore, enhances the energy security of the United States in a green and environmentally friendly manner. The objective of this study is to evaluate alternatives and recommend equipment to develop into hybrid energy conversion and storage systems for deep ocean operations. Such power systems will be located on the ocean floor and will be used to power offshore oil and gas exploration and production operations. Such power systems will be located on the oceans floor, and will be used to supply oil and gas exploration activities, as well as drilling operations required to harvest petroleum reserves. The following conceptual hybrid systems have been identified as candidates for powering sub-surface oil and gas production operations:
1. $P W R=$ Pressurized-Water Nuclear Reactor + Lead-Acid Battery
2. $\mathrm{FC1}=$ Line for Surface $\mathrm{O}_{2}+$ Well Head Gas + Reformer + PEMFC + Lead-Acid \& Li-lon Batteries
3. $\mathrm{FC2}=$ Stored $\mathrm{O} 2+$ Well Head Gas + Reformer + Fuel Cell + Lead-Acid \& Li-Ion Batteries
4. $\mathrm{SV} 1=$ Submersible Vehicle + Stored $\mathrm{O}_{2}+$ Fuel Cell + Lead-Acid $\&$ Li-lon Batteries
5. SV2 $=$ Submersible Vehicle + Stored $\mathrm{O}_{2}+$ Engine or Turbine + Lead-Acid \& Li-lon Batteries
6. SV3 $=$ Submersible Vehicle + Charge at Docking Station + ZEBRA \& Li-lon Batteries
7. $P W R T E G=P W R+$ Thermoelectric Generator + Lead-Acid Battery
8. WELL TEG $=$ Thermoelectric Generator + Well Head Waste Heat + Lead-Acid Battery
9. GRID = Ocean Floor Electrical Grid + Lead-Acid Battery
10. DOC $=$ Deep Ocean Current + Lead-Acid Battery 


\section{Background}

$\underline{\text { Importance of Investigation }}$

As oil and gas reserves on shore or in close proximity to shore are exhausted, it will be necessary to develop fields further from shore and at greater depths. At some point, it may prove to be beneficial to locate both the production equipment, as well as the associated power generation equipment on the ocean floor. This study has explored a variety of conceptual hybrid power generation options for such applications, each evaluated at eight representative deep-ocean concept-of-operations (con-ops) sites.

An investment in sub-sea (deep-ocean) hybrid power systems is required to enable off-shore oil and gas exploration and harvesting. Advanced deep-ocean drilling operations, locally powered, will provide access to oil and gas reserves otherwise inaccessible. Such technology will therefore enhance the energy security of the United States. The oil and gas industry is being pushed beneath the surface by economic concerns. According to The Economist (September 8th - 14th 2007), there is a "sea change" in off-shore drilling technology. In regard to off-shore technology, they state that "rising costs and clever kits are transforming the oil-platform, and could even do away with it all together." The article discusses the cost and manpower required to operate a typical oil and gas platform in the middle of the North Sea. There are 435 such platforms in the British waters of the North Sea alone. In regard to costs, the Alwyn North Oil and Gas Platform was built for a cost of $£ 1.5$ billion (\$2.4 billion) in the mid 1980's and has spent nearly half that amount upgrading the platform since its construction. Operation of this platform requires that approximately 300 personnel live aboard, with each receiving 3-weeks leave for every 2 weeks on the platform, and an associated cost for flying each to and from the platform being $f 1,000$. According to Oil and Gas United Kingdom, an industry group, oil firms spent over $£ 11$ billion last year building and running offshore facilities in British waters alone. Such operating costs places production costs for one barrel of oil at $\$ 22$ per barrel, which is nearly the highest in the world. These costs are rising rapidly. The Deutsche Bank estimates that inflation in the oil business has run at $30 \%$ a year over the past two years, and will continue to rise by at least $15 \%$ per year through 2008 . The article goes on to state:

"No wonder, then, that firms are determined to reduce the expense of producing oil at sea, in the North Sean and elsewhere."

"Even more distant fields can be tied back to a platform using pipelines along the sea floor. In a tieback, the valves that open and close the well are located not on the rig, but on the sea floor; engineers operate them by rmote control. Several deposits of oil and gas, including Nuggets, a cluster of gas fields over $40 \mathrm{~km}$ away, are linked to Alwyn North in this way. Next, Total plans to connect a new discovery called Jura to the platform. As a result, the lifespan of Alwyn North, estimated at 10 years when it first started production in 1987, has been extended to over 40 years, while its projected output has almost quadrupled."

"The next logical step is to put more equipment underwater, in the hope of dispensing with platforms altogether. Statoil, for example, is tapping a gas filed called Snohvit, which lies $143 \mathrm{~km}$ off-shore, without using a platform. But this is possible only because the pressure of the field is strong enough 
to keep the gas flowing through the long pipeline back to offshore. Norsk Hydro, another Norweigian energy firm on the verge of merging with Statoil, has developed another gas field, Ormen Lange, in the same way. But in a few years a compressor that can work underwater will be needed to supplement the falling pressure in the field. Last year, Norsk Hydro hired General Electric (GE), an American industrial giant, to build a prototype.

"Fifteen years from now, "says Claudi Santiago of GE, "The vision is that offshore platforms will disappear."

"Or maybe not ... If some way can be found to liquiefy gas offshore, Mr. Santiago points out, then deposits that are currently too remote for the construction of pipelines could be developed, and the gas transported in liquid form by ship instead. That would give offshore platforms a whole new life."

Clearly, there is a strong driving force for the development of sub-sea capabilities on the ocean floor. Such facilities will require ample supplies of local power to operate machinery on the floor, ranging from drills to pumps and compressors. Once can even envision safe, efficient and economical submarine tanker fleets to transport fuel, thereby eliminating the need for pipline construction and transport altogether. Such tankers could rely on natural-gas powered fuel cells, with power system construction analogous to that of the publicized HDW sub-sea vessels.

\section{Concept-of-Operation Sites Serving as Basis for Study}

Eight representative deep-ocean concept-of-operations (con-ops) sites with a wide range of locations, depths, tie-back distances, and power requirements, were selected for this study and are summarized in Table 1. Shtokman (Barents Sea) and Ormen Lange (Norway) have the greatest requirement for electrical power, at approximately 240 and 60 megawatts-electrical, respectively, and also have the greatest tie-back distances, 209 and 193 miles, respectively. The sites at the greatest depths are Chinook and Perdido (Gulf of Mexico), located at approximately 8,800 and 7,999 feet respectively, but have relatively short tie-back distances of approximately 12 miles, and modest power requirements, 7.2 and 5 megawatts-electrical, respectively. The Marimba Field (Campros Basin) has the least power requirement, at only 80 kilowatts-electrical, is located at a depth of only 1,296 feet, and has a tie-back distance of only 1 mile. While the power requirements, tie-back distance, and location for Shtokman and Ormen Lange appear to be sufficiently challenging to warrant extraordinary measures for power, it would be surprising if such measures could be justified at the Marimba Field. All have been included in this study to provide a wide range of scenarios.

\section{Hybrid Energy Conversion and Storage Systems Considered}

Based upon a preliminary screening of power generation and energy storage technologies, ten conceptual, energy conversion and storage, hybrid systems were developed for evaluation at each of the eight con-ops sites. These conceptual hybrid systems are summarized in Table 2 and repeated below: 
1. $P W R=$ Pressurized-Water Nuclear Reactor + Lead-Acid Battery

2. $\mathrm{FC1}=$ Line for Surface $\mathrm{O}_{2}+$ Well Head Gas + Reformer + PEMFC + Lead-Acid \& Li-Ion Batteries

3. $\mathrm{FC2}=$ Stored $\mathrm{O} 2+$ Well Head Gas + Reformer + Fuel Cell + Lead-Acid \& Li-Ion Batteries

4. $\mathrm{SV} 1=$ Submersible Vehicle + Stored $\mathrm{O}_{2}+$ Fuel Cell + Lead-Acid \& Li-Ion Batteries

5. SV2 $=$ Submersible Vehicle + Stored $\mathrm{O}_{2}+$ Engine or Turbine + Lead-Acid \& Li-lon Batteries

6. $\mathrm{SV} 3=$ Submersible Vehicle + Charge at Docking Station + ZEBRA \& Li-lon Batteries

7. $P W R T E G=P W R+$ Thermoelectric Generator + Lead-Acid Battery

8. WELL TEG $=$ Thermoelectric Generator + Well Head Waste Heat + Lead-Acid Battery

9. GRID = Floor Electrical Grid + Lead-Acid Battery

10. DOC = Deep Ocean Current + Lead-Acid Battery

\section{Energy Conversion Technologies}

Several energy conversion technologies have been considered: (1) proton-exchange membrane fuel cells powered with hydrogen and oxygen, similar to that used on proven subsurface vessels; (2) fuel-cells capable of using natural gas from deep-ocean wells; (3) internal combustion engines powered with natural gas from deep-ocean wells; (4) turbines powered with natural gas from deep-ocean wells; (5) solid-state thermoelectric and thermionic generators powered with natural gas from deep-ocean wells, geothermal sources, and radioisotopes; (7) renewable energy sources at the surface, including solar, wind and wave powered generators; (9) renewable energy sources on the sea floor, including turbines powered with ocean current; and (8) small pressurized-water reactors with low-enrichment fuel, similar

to those used on the NS Savannah and NS Otto Hahn commercial ships (Appendix A, Figure A1). The performance characteristics of the leading candidates are summarized in Table 3.

\section{Nuclear Energy}

At the present time, there are more than 441 light water reactors (LWRs) worldwide, withy a total generating capacity of $358.7 \mathrm{GWe}$ (Appendix A, Table A1). These reactors have generated more than 171,000 metric tons of spent nuclear fuel that must be stored at reactor sites, reprocessed, or ultimately disposed of in geologic repositories (Appendix A, Table A2).

Small modular nuclear reactors are currently being investigated for deployment at remote locations (Appendix A, Table A3). The m-Power reactor being developed by Babcock and Wilcox (B\$W) of Lynchburg, Virginia is discussed in a front-page article of the Wall Street Journal [Smith 2010], and leverages a long history of success with earlier designs (Appendix A, Figures A2 through A4). This small PWR has a power of 125 megawatts, a coolant temperature and pressure of $620^{\circ} \mathrm{F}(600 \mathrm{~K})$ and $2000 \mathrm{psi}$ $(14 \mathrm{MPa})$, and a steam pressure of $1000 \mathrm{psi}(7 \mathrm{MPa})$. The $\mathrm{m}$-Power reactor has a volume of 158 cubic meters and a weight of 500 metric tons. It is fueled with uranium enriched to 7.0 percent $\mathrm{U}-235$. This modular reactor has been designed to have an endurance of 1,825 days (time between refueling operations). The $\mathrm{m}$-Power reactor has extremely high specific power, power density, specific energy and energy density: $250 \mathrm{~W} / \mathrm{kg}, 792 \mathrm{~W} / \mathrm{L}, 10,950,000 \mathrm{Wh} / \mathrm{kg}$, and 34,672,967 Wh/L, respectively. 
Small modular nuclear reactors are capable of producing immense electrical power, and require relatively little mass or volume. This has led to their application in military ships and boats, including aircraft carriers and submarines. Nuclear powered submarines of several countries have now operated in the oceans of the world for nearly fifty years. While such military systems are both unavailable and inappropriate for the oil and gas industry to consider, other types of nuclear power plants have been successfully deployed onboard commercial ships. For example, compare the Babcock and Wilcox (B\&W) pressurized water reactor (PWR) used to power the NS Otto Hahn with the power available from highperformance automotive and aircraft engines:

- $\quad$ Auto and Aircraft Engines: 100-1000 kW / 0.9 to $1.1 \mathrm{~kW} / \mathrm{kg}$

- $\quad$ NS Otto Hahn PWR: $38 \mathrm{MW} / 22.4 \mathrm{~kW} / \mathrm{kg} / 4.8$ to $105 \mathrm{kWh} / \mathrm{kg}$

The NS Otto Hahn and NS Savannah Nuclear had displacements of 16,871 and 22,000 metric tons, and had pressurized water reactors capable of producing 38 and 74 megawatts, respectively. The NS Otto Hahn had a core volume of 35 cubic meters, and was fueled with 1.7 metric tons of uranium enriched to 3.5 to 6.6 percent U-235. This nuclear powered ship had an endurance of 900 days (time between refueling operations).

NS Otto Hahn Nuclear Powered Ship (1964-79)

- Builder Howaldtswerke Deutsche Werft AG of Kiel

- Displacement: 25,790 tons (Full); 16,871 tons (Standard)

- Length: $164.3 \mathrm{~m}$ (Waterline); $172.0 \mathrm{~m}$ (Overall)

- Beam: $23.4 \mathrm{~m}$

Nuclear Reactor on NS Otto Hahn

- Deutsche Babcock \& Wilcox-Dampfkesselwerke AG und Internationale Atomreaktorbau GmbH

- Reactor Power: $38 \mathrm{MW}$

- Volume: $35 \mathrm{~m}^{3}$

- Pressure: $85 \mathrm{kp} / \mathrm{cm}^{2}(8.3 \mathrm{MPa})$

- Temperature: $300^{\circ} \mathrm{C}$

- Fuel: 1.7 metric tons of 3.5-6.6\% enriched uranium

- Endurance under full load: 900 days

- Average fuel burn-up: 23,000 MW day ton ${ }^{-1}$

- Average thermal neutron flux: $1.1 \times 1013 \mathrm{~cm}^{-2} \mathrm{~s}^{-1}$

- Number of elements/fuel rods: $12 / 2810$

- Equivalent minor diameter: $1050 \mathrm{~mm}$

- Active core height: $830 \mathrm{~mm}$

- Fuel rod diameter: $11.4 \mathrm{~mm}$

- Fuel cladding: $0.8 \mathrm{~mm}$ of Zircaloy-4 
NS Savannah Nuclear Powered Ship (1970-79)

- New York Shipbuilding, Camden, NJ

- Displacement: 22,000 tons

- Overall length: $596 \mathrm{ft}(180 \mathrm{~m})$

- Beam: $78 \mathrm{ft}(23.8 \mathrm{~m})$

- Load carrying capacity: 14,040 tons

- Watertight compartments: 14

- Loading spaces: 6

- Complement: $124 \mathrm{crew}, 60$ passengers

- Single propeller: $20,300 \mathrm{hp}$

- Cruising speed: 21 knots $(40 \mathrm{~km} / \mathrm{h})$

- Top speed: 24 knots (47 km/h)

Nuclear Reactor on NS Savannah

- Manufacturer: Babcock \& Wilcox

- Power: $74 \mathrm{MW}$

Other reactor-driven technologies also exist, such at the SNAP 8 reactor-powered Rankin Cycle, which used mercury as the working fluid. Such systems could provide vast amounts of energy for oil and gas facilities on the sea floor. These systems will be explored as part of the proposed study, and will be compared to competing technologies.

\section{PEMFC Powered with Hydrogen from Well Head Gas Reformer}

The high reliability of fuel cells, coupled with high energy density, have led to their use in a variety of demanding applications, ranging from space exploration to sub-sea vessels with long endurance. Protonexchange membrane fuel cells, with solid-state hydrogen storage and liquid oxygen have been developed and used by HDW in Kiel Germany for powering small sub-sea vessels (Figures 5 through 8). A variant of this air-independent-propulsion system has also been developed which substitutes hydrogenpowered Sterling engines for the PEM fuel cell. These small and efficient submarines have now been produced in relatively large numbers. Thus, the viability of sub-sea fuel-cell systems for demanding large-scale applications has been unambiguously demonstrated.

The components of the fuel cell system used by HDW shipyard in Kiel, Germany aboard sub-sea vessels such as the Class 212A Submarine (Appendix B, Figures B1 through B4). This subsea vehicle is powered by a proton-exchange membrane fuel cell (PEMFC), and has solid-state hydrogen storage canisters that are filled with iron-titanium hydride. The oxygen for this oxygen-breathing electrochemical energy conversion system is stored in a cryogenic tank.

The most obvious extension of HDW-type technology to sea floor operations for the oil and gas industry could involve the use of subsea vehicles to bring air to the ocean floor so that well head methane could 
be burned by on-board fuel cells, internal combustion engines, or gas turbines to generate local power for well-head equipment, such as drilling and pumping stations. Alternatively, such vehicles could carry large battery packs to the ocean floor, after charging at the surface with renewable sources of energy. Such mobile systems could also be used as subsea tankers, helping mitigate the need for pipelines for transporting oil and natural gas.

Natural gas from deep-ocean wells would be a logical energy source for supplying sub-surface fuel cells at deep-ocean production sites. The composition and properties of oil and gas for typical subsea wells have been published in the literature (Appendix C, Tables C1 through C5 and Figures C1 through C3) [Gonzalez SPE 110833]. Natural gas from the well could be converted to hydrogen via a reformer, and fed to an environmentally benign, ambient temperature PEMFC via gas purification membranes, required to filter out electro-catalytic poisons, including carbon monoxide and sulfur-bearing chemical species. This option could potentially eliminate the need for pipelines to transport natural gas away from subsea well heads. Alternatively, the natural gas could be used directly to fuel a high temperature solid oxide fuel cell (SOFC), though the operation of such a high temperature system on the sea floor poses additional complications.

The steam reforming of natural gas (NG) or methane $\left(\mathrm{CH}_{4}\right)$ from the well head to hydrogen that can be burned in a proton exchange membrane fuel cell (PEMFC) occurs via two sequential reactions. The first reaction is:

$$
\mathrm{CH}_{4}+\mathrm{H}_{2} \mathrm{O} \longrightarrow \mathrm{CO}+3 \mathrm{H}_{2}
$$

This reaction is endothermic with an estimated heat-of-reaction of approximately $206.16 \mathrm{~kJ}$ per mol-NG (57.27 Wh/mol-NG or 3,579 Wh/kg-NG).

$$
\mathrm{CO}+\mathrm{H}_{2} \mathrm{O} \longrightarrow \mathrm{CO}_{2}+\mathrm{H}_{2}
$$

This reaction is moderately exothermic with an estimated heat-of-reaction of approximately $-41.16 \mathrm{~kJ}$ per mol-NG $(-11.43 \mathrm{Wh} / \mathrm{mol}-\mathrm{NG}$ or $-715 \mathrm{Wh} / \mathrm{kg}-\mathrm{NG})$. The overall chemical reaction involved for the conversion of methane to hydrogen in the reformer is:

$$
\mathrm{CH}_{4}+\mathrm{H}_{2} \mathrm{O} \longrightarrow \mathrm{CO}_{2}+4 \mathrm{H}_{2}
$$

This reaction is moderately endothermic, with an estimated heat-of-reaction of approximately $165.00 \mathrm{~kJ}$ per mol-NG ( $45.83 \mathrm{Wh} / \mathrm{mol}-\mathrm{NG}$ or $2,865 \mathrm{Wh} / \mathrm{kg}-\mathrm{NG}$ ). As an approximation, it is assumed that both products and reactants are gases at ambient temperature and pressure. The overall efficiency of the reformer is assumed to be approximately $70-85 \%$, which is representative. Hydrogen from the reformer is then burned in the PEMFC via the following reaction:

$4 \mathrm{H}_{2}+2 \mathrm{O}_{2} \longrightarrow \mathrm{CO}_{2}+2 \mathrm{H}_{2} \mathrm{O}$

The difference in enthalpy between the products and reactants is approximately $-241.83 \mathrm{~kJ}$ per mol-NG (-67.18 Wh/mol-NG or $-4,198 \mathrm{Wh} / \mathrm{kg}-\mathrm{NG})$. The corresponding change in Gibbs free energy is reflected in 
the electrochemical potential for this reaction, which under standard conditions is approximately 1.23 volts. The efficiency of the PEMFC is assumed to be approximately $65-75 \%$, which is representative. The overall reaction for the conversion of methane to $\mathrm{CO}_{2}$ and $\mathrm{H}_{2} \mathrm{O}$ in the combined reformer and fuel cell system is:

$\mathrm{CH}_{4}+2 \mathrm{O}_{2} \longrightarrow \mathrm{CO}_{2}+2 \mathrm{H}_{2} \mathrm{O}$

The difference in enthalpy between the products and reactants is approximately $-802.32 \mathrm{~kJ}$ per mol-NG (-222.87 Wh/mol-NG or -13,929 Wh/kg-NG).

$\underline{\text { Turbine or Internal Combustion Engine Power with Natural Gas from Well Head Gas Reformer }}$

The reaction for burning methane in an internal combustion engine or turbine is:

$\mathrm{CH}_{4}+2 \mathrm{O}_{2} \longrightarrow \mathrm{CO}_{2}+2 \mathrm{H}_{2} \mathrm{O}$

The difference in enthalpy between the products and reactants in this case is also approximately -802.32 kJ per mol-NG (-222.87 Wh/mol-NG or $-13,929 \mathrm{Wh} / \mathrm{kg}-\mathrm{NG})$.

Gas Turbine or Internal Combustion Engine Powered with Natural Gas from Well Head

The reaction for burning methane in an internal combustion engine or turbine is:

$\mathrm{CH}_{4}+2 \mathrm{O}_{2} \longrightarrow \mathrm{CO}_{2}+2 \mathrm{H}_{2} \mathrm{O}$

The difference in enthalpy between the products and reactants in this case is also approximately -802.32 kJ per mol-NG (-222.87 Wh/mol-NG or $-13,929 \mathrm{Wh} / \mathrm{kg}-\mathrm{NG})$.

Thermoelectric Generator Powered by Heat from Well-Head or Nuclear Reactor

Solid-state thermoelectric generators have no moving parts, and can be used for the reliable direct conversion of heat to electrical energy, with exceptional reliability in remote and inaccessible locations, including deep space. Such energy converters could be powered on the sea floor in a variety of ways, including geothermal heat sources, heat from the combustion of natural gas from deep ocean wells, decay heat from radioisotopes, and small deployable nuclear reactors. Examples of thermoelectric generators that have been powered by small nuclear reactors and radioisotope sources include:

- SNAP 10: Reactor-Powered Thermoelectric Generator

- SNAP 19: Radioisotope Thermoelectric Generator

- SNAP 27: Radioisotope Thermoelectric Generator

Radioisotope sources with the necessary power density for the applications of interest to the oil and gas industry are believed to be too limited for serious consideration, but are included for completeness. Small deployable proliferation-resistant reactors may become a viable option in the coming years, and are now being considered for other applications. 
Thermoelectric power generators are $\mathrm{p}-\mathrm{n}$ junctions in which charge carriers and heat flow in parallel. Electrons and holes must acquire energy at the $p$-n junction to flow in a direction opposite to the temperature gradient (from cold to hot). Both ohmic heating and heat conduction must be minimized for the efficient operation of such devices. The thermodynamic efficiency of a thermoelectric power generator $(\eta)$ is calculated from the dimensionless figure-of-merit $(Z T)$. The dimensionless figure of merit, $Z T$, is determined by Seebeck coefficient $(\alpha)$, electrical conductivity $(\sigma)$, electronic thermal conductivity $\left(\kappa_{e l}\right)$, and lattice thermal conductivity $\left(\kappa_{p h}\right)$.

$$
Z T=\frac{\sigma \alpha^{2}}{\kappa_{p h}+\kappa_{e l}} T
$$

The expressions for $\eta$ at the optimum current level is

$$
\eta=\frac{T_{h}-T_{c}}{T_{h}} \frac{\sqrt{1+Z T}-1}{\sqrt{1+Z T}+T_{c} / T_{h}}
$$

$T$ is the average temperature of the device, $T_{h}$ is the hot temperature and $T_{c}$ is the cold temperature. To achieve high values of $\eta$ with a thermoelectric device, a material with a large $Z T$ value must be found. Commonly used materials and the dependence of $\eta$ on $Z T, T_{c}$ and $T_{h}$ can be found in the appendices (Appendix D, Table D1 and Figure D1)

The efficiencies of thermoelectric generators are limited by the properties of the solid state materials used in their construction, and the available temperature gradient. Promising thermoelectric materials should have high power factors $\left(\sigma \alpha^{2}\right)$ and low thermal conductivities $\left(\kappa_{p h}+\kappa_{e l}\right)$. Furthermore, such materials should be plentiful enough (and sufficiently inexpensive) to enable the possible construction of large-scale devices. Degenerate semiconductors have the best combinations of these intrinsic properties.

\section{Deep Ocean Currents}

The use of deep ocean currents as an environmentally benign method of supplying power will also be investigated. Swiftly flowing ocean currents represent a significant untapped renewable energy resource. State-of-the art turbine designs will technology will be investigated collaboratively with these potential vendors and industrial partners from the oil and gas industry. The successful deployment of this energy conversion technology requires detailed knowledge of oceanographic parameters, including seasonal currents, surface wind and wave fields. Secondary ocean characteristics that must also be taken into consideration include: biological fouling potentials, the stability of the local sediments, their ability to accept moorings, and the potential for catastrophic storms.

While the conversion of deep ocean currents to electrical power is analogous to the conversion of terrestrial winds to electrical power, obvious differences in operating environment lead to very different mechanical and electrical designs. The turbines used for deep ocean applications are heavier and less agile than those used for wind generation since the density of seawater is three orders-of-magnitude 
greater than the density of air, and since ocean current velocities are less and more predictable than those of wind.

GCK is developing the Gorlov Helical Turbine (GHT). This technology provides a source of electricity by extracting the kinetic energy from flowing water (Appendix E, Figure E1). It is designed for hydroelectric applications in free flowing watercourses. The GHT is a cross-flow turbine with airfoil-shaped blades that provide a reaction thrust that can rotate the GHT at twice the speed of the water flow. It is self-starting and can produce power from a water current flow as low as about 3 knots $(1.5 \mathrm{~m} / \mathrm{s})$ with power increasing in proportion to the water velocity cubed. A thorough review of turbine technologies, such as those developed by GCK, OpenHydro and others will be done. The readiness of this technology for deployment will be determined, using results from testing.

System design must consider under-water maintenance issues. The unavoidable corrosion and biofouling of turbine materials complicates the deployment of such deep ocean systems. However, recent advances in material technology, such as the use of thermal-spray coatings of high-performance corrosion-resistant amorphous-metal alloys, anti-fouling coatings, and carefully designed cathodic protection systems promise to mitigate such problems. Given the scale of the energy systems that are required, these materials will also need to be economical, minimizing the use of expensive alloying elements such as those used in conventional high-performance Ni-Cr-Mo alloys.

\section{Energy Storage Technologies}

Energy storage must be integrated with the selected energy conversion technology, thereby creating a hybrid system capable of providing a constant source of electrical power for pumps, drill motors, and other equipment. For example, turbines driven by fluctuating currents of wind and ocean will produce unsteady current, which will have to be rectified and used to charge batteries, which in turn can be used as a steady source of electrical power for pumps and motors.

The energy storage technologies that will be explored include: compressed-gas storage; liquid red-ox batteries; secondary batteries in sealed pressure vessels; pressure-tolerant secondary batteries; and other systems. Various energy storage technologies will be considered, and will include a wide range of conventional \& unconventional batteries will be considered.

- Mechanical flywheels

- Compressed-gas storage

- Regenerative liquid red-ox batteries

- Lead-acid batteries

- Silver-zinc batteries

- Sodium-beta batteries

- Lithium-ion batteries

- Regenerative fuel cells 
From this list of options, only the rechargeable batteries and the regenerative fuel cell were evaluated in detail. A summary of key attributes of energy storage options used to assess hybrid system options is presented in Table 4 with additional information is given in the appendices (Appendix F, Table F1 and Figures F1 through F6).

\section{$\underline{\text { Lead-Acid Batteries }}$}

The lead-acid battery has a metallic anode made of a lead alloy, a lead-oxide cathode, a porous polyethylene separator, and an electrolyte of concentrated sulfuric acid. This battery can operate from 20 to $+60^{\circ} \mathrm{C}$. The open-circuit voltage is $2.1 \mathrm{~V}$, with operation between 2.0 and $1.75 \mathrm{~V}$. The specific power, power density, specific energy and energy density are $20 \mathrm{~W} / \mathrm{kg}, 51 \mathrm{~W} / \mathrm{L}, 20-35 \mathrm{Wh} / \mathrm{kg}$, and 50-90 $\mathrm{Wh} / \mathrm{L}$, respectively. The cycle life of a typical lead acid battery can be as long as 1100 cycles (to $80 \%$ of the original capacity). The cost of energy storage is approximately $\$ 150$ per kilowatt-hour. In summary, lead-acid batteries are proven technology, with a long history of sub-surface application in submarines. The lead-acid battery is relatively heavy, but is expensive and should be considered for the RPSEA application.

\section{$\underline{\text { Silver Zinc Batteries }}$}

The silver-zinc battery has a metallic anode made of a zinc alloy, a silver-oxide cathode, a cellophane separator, and an electrolyte of $40 \%$ potassium hydroxide. This battery can operate from -20 to $+60^{\circ} \mathrm{C}$. The open-circuit voltage is $1.86 \mathrm{~V}$, with operation between 1.7 and $1.3 \mathrm{~V}$. The specific power, power density, specific energy and energy density are 5560-1470 W/kg, 9530-2520 W/L, 105-110 Wh/kg, and 180-300 Wh/L, respectively. The cycle life of a typical silver-zinc battery is limited, with a maximum live of approximately 250 cycles (to $80 \%$ of the original capacity). The cost of energy storage is approximately $\$ 600$ per kilowatt-hour, which reflects the high cost of the silver used in the cathode. In summary, lead-acid batteries are proven technology, with a long history of sub-surface application in torpedoes and other sub-surface vehicles. The silver-zinc battery is relatively expensive, suffers from short cycle life, but has exceptional specific power and power density, and specific energy and energy density rivaling that possible with state-of-the-art (SOA) lithium-ion batteries. The limited cycle life prevents it from be a good candidate for RPSEA applications.

\section{Sodium-Sulfur Batteries}

The sodium-sulfur battery is categorized as a sodium-beta battery. It has a molten sodium anode, a $\beta^{\prime \prime}-$ $\mathrm{Al}_{2} \mathrm{O}_{3}$ ceramic separator, which also serves as the solid-state, $\mathrm{Na}^{+}$-conductive electrolyte, and a molten sulfur cathode. This battery is challenged by the need for a relatively high operating temperature of 290 to $390^{\circ} \mathrm{C}$. The open-circuit voltage is $2.08 \mathrm{~V}$, with operation between 1.95 and $1.78 \mathrm{~V}$. The specific power, power density, specific energy and energy density are 390-250 W/kg, 604-386 W/L, 117-226 $\mathrm{Wh} / \mathrm{kg}$, and 147-370 Wh/L, respectively. The sodium-sulfur battery has exceptional cycle life, with a maximum life of approximately 2,250 cycles (to $80 \%$ of the original capacity), making it a reasonable choice for remote deployment where maintenance would be difficult. Despite the use of molten alkali electrodes, which can react with air and water, this battery has a very good safety record. No gaseous 
reaction products are formed during overcharge, and the separator tends to be self-healing. The cost of energy storage is approximately $\$ 300$ per kilowatt-hour, which is modest. In summary, sodium-sulfur batteries are proven technology, with a solid history of applications in grid-storage (NGK Corporation of Japan). The sodium-sulfur battery is a reasonable contender for RPSEA sub-surface applications, but will require insulated battery bottles, and auxiliary heating equivalent to approximately $10 \%$ of the batteries stored energy [Reference: Joseph C. Farmer, Lawrence Livermore National Laboratory, 2009].

\section{$\underline{\text { ZEBRA Batteries }}$}

The ZEBRA battery is also categorized as a sodium-beta battery, like the sodium-sulfur battery. The ZEBRA also has a molten sodium anode and a $\beta^{\prime \prime}-\mathrm{Al}_{2} \mathrm{O}_{3}$ ceramic separator, which also serves as the solidstate, $\mathrm{Na}^{+}$-conductive electrolyte, but has a $\mathrm{Ni} / \mathrm{NiCl}_{2}$ cathode with a secondary $\mathrm{NaAlCl}_{4}$ electrolyte, instead of the sulfur-based cathode used in the sodium-sulfur battery. This battery is also challenged by the need for a relatively high operating temperature of 220 to $450^{\circ} \mathrm{C}$. The open-circuit voltage is approximately $2.58 \mathrm{~V}$, with operation believed to occur between 2.25 and $1.72 \mathrm{~V}$, slightly higher than the terminal voltage of the sodium-sulfur battery. The specific power, power density, specific energy and energy density are 171-169 W/kg, 265-261 W/L, 94-119 Wh/kg, and 148-183 Wh/L, respectively, lower than that possible with sodium-sulfur technology. The ZEBRA battery has exceptional cycle life, even better than that achieved with the sodium-sulfur battery, with a maximum life of approximately 3,500 cycles (to $80 \%$ of the original capacity), making it a reasonable choice for remote deployment where maintenance would be difficult. The cost of energy storage is only $\$ 220$ per kilowatt-hour, which is less than that for the sodium-sulfur battery. In summary, sodium-sulfur batteries are proven technology, with a solid history of applications in transportation (electrical school buses for the Sacramento Utility District, and delivery vans in Europe), grid-storage (Canada), and deep-ocean applications (NATO DSRV, or deep-sea rescue vehicle). The ZEBRA battery is a reasonable contender for RPSEA sub-surface applications, but will require insulated battery bottles, and auxiliary heating equivalent to approximately $10 \%$ of the batteries stored energy [Reference: Joseph C. Farmer, Lawrence Livermore National Laboratory, 2009].

\section{$\underline{\text { Lithium Ion Batteries }}$}

The modern lithium-ion battery has: an anode that consists of a graphite-based active material (Li-C6) with carbon filler and PVDF binder coated onto a copper foil current collector; a cathode that consists of a transition metal oxide or iron phosphate $\left.\left(\mathrm{Li}-\mathrm{NiO}_{2}, \mathrm{Li}-\mathrm{CoO}_{2}, \mathrm{Li}-\mathrm{MnO}_{2} \text {, or } \mathrm{Li}-\mathrm{FePO}\right)_{4}\right)$ active material with a PVDF binder coated onto an aluminum foil current collector; a microporous porous polyethylene separator, and an electrolyte consisting of a mixed organic carbonate solvent (EC:DMC:DEC) and LiPF 6 salt. Of course, more advanced materials are evolving, such as the lithium titanate anode $\left(\mathrm{Li}^{-} \mathrm{Ti}_{2} \mathrm{O}_{4}\right)$ and solid state electrolytes such as LiPON ${ }^{\mathrm{TM}}$. The liquid cylindrical or prismatic cells are contained in a hermetically sealed metal can, while polymer-gel cells are contained in a soft aluminum-polyethylene laminate package, with thermally laminated seams. In the case of the polymer-gel cell, the polyethylene separator is usually coated on both sides with porous PVDF layers. This battery can operate from -40 to $+60^{\circ} \mathrm{C}$. The open-circuit voltage is $4.1 \mathrm{~V}$, with operation between 4.0 and $3.0 \mathrm{~V}$ (possibly as low as $2.8 \mathrm{~V}$ ). The specific power, power density, specific energy and energy density are 1100-74 W/kg, 2270-147 W/L, 
75-182 Wh/kg, and 139-359 Wh/L, respectively. The cycle life of the best state-of-the-art lithium-ion batteries can be as great as 1500 cycles (to $80 \%$ of the original capacity). However, poorly constructed cells can have much shorter lives (300 cycles representing poorer cells). Based upon published data, the cost of energy storage is believed to be approximately $\$ 300$ per kilowatt-hour (though some quote $\$ 1000$ per kilowatt-hour). In summary, lithium-ion batteries are proven technology, and are leading candidates for terrestrial electric vehicles. This technology has also enjoyed limited but successful use in autonomous underwater vehicles used for oceanographic research. Unfortunately, lithium ion batteries have been plagued by a history of significant safety incidents, with some causing serious human injury and property damage (loss of commercial cargo plane, for example). The lithium-acid battery may prove to be relatively expensive, has safety issues that must be dealt with, but has exceptional performance characteristics, that make it a leading candidate for consideration. Designs would have to emphasize safety, thermal management during charge and discharge, and enhanced battery management systems.

\section{$\underline{\text { Regenerative Fuel Cells }}$}

During discharge, regenerative fuel cells burn stored hydrogen and oxygen, with the production of electricity and water. Due to the energy penalty associated with separating pure water from seawater (theoretical minimum of $2.5 \mathrm{Wh} /$ gal, with actual values of 24-36 Wh/gal required for separation with reverse osmosis), the pure water produced by the oxidation of hydrogen in the fuel cell is stored during discharge. During recharging, this stored water is electrolyzed, with the formation of both hydrogen and oxygen, which is stored. In this case, we assume that the gases would be stored in bottles at a pressure of approximately 10,000 pounds per square inch absolute (psia). Assuming that a proton exchange membrane fuel cell (PEMFC) is used as the basis for this system, the air cathode would consist of a dispersed platinum catalyst on a porous carbon substrate, the hydrogen anode would consist of a dispersed platinum or platinum-ruthenium catalyst on a porous substrate, and the electrolyte is a

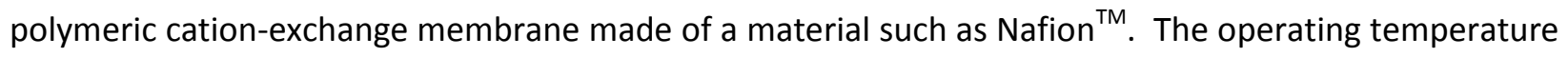
of a PEMFC ranges from 30 to $120 \mathrm{C}^{\circ}$. The open circuit voltage of such a regenerative fuel cell would be approximately $1.2 \mathrm{~V}$, while the expected operating voltage under load would be 0.5-0.7 V. The specific power and power density of such a system would be approximately $27 \mathrm{~W} / \mathrm{kg}$ and $17 \mathrm{~W} / \mathrm{L}$, while the specific energy and energy density would be approximately $326 \mathrm{Wh} / \mathrm{kg}$ and $209 \mathrm{Wh} / \mathrm{L}$, respectively. Such systems provide greater specific energy and energy density than SOA secondary batteries, but have limited power density. The power density dictates the size of such systems in high power applications. Therefore, regenerative fuel cells are not considered good choices for the RPSEA application.

\section{Hybrid Energy Conversion and Storage Systems}

Hybrid systems use energy conversion devices with high specific power to efficiently achieve high levels of current, and energy storage devices with high specific energy to enable sustained operation in the event that the primary power generation systems fails. Typical ranges of power and energy densities are given in the appendices (Appendix G, Figure G1). The following combinations of energy conversion and storage devices have been evaluated in this study as candidate hybrid systems for powering subsea oil and gas production operations: 
1. $P W R=$ Pressurized-Water Nuclear Reactor + Lead-Acid Battery

2. $\mathrm{FC1}=$ Line for Surface $\mathrm{O}_{2}+$ Well Head Gas + Reformer + PEMFC + Lead-Acid \& Li-Ion Batteries

3. $\mathrm{FC2}=$ Stored $\mathrm{O} 2+$ Well Head Gas + Reformer + Fuel Cell + Lead-Acid \& Li-Ion Batteries

4. SV1 $=$ Submersible Vehicle + Stored $\mathrm{O}_{2}+$ Fuel Cell + Lead-Acid $\&$ Li-lon Batteries

5. $\mathrm{SV} 2=$ Submersible Vehicle + Stored $\mathrm{O}_{2}+$ Engine or Turbine + Lead-Acid \& Li-Ion Batteries

6. SV3 $=$ Submersible Vehicle + Charge at Docking Station + ZEBRA \& Li-Ion Batteries

7. $P W R T E G=P W R+$ Thermoelectric Generator + Lead-Acid Battery

8. WELL TEG $=$ Thermoelectric Generator + Well Head Waste Heat + Lead-Acid Battery

9. GRID = Floor Electrical Grid + Lead-Acid Battery

10. $\mathrm{DOC}=$ Deep Ocean Current + Lead-Acid Battery

The intrinsic advantages of fuel cell systems include: high energy density, which scales linearly with the quantity of fuel stored within the system or available at the site where the fuel cell is operated; exceptional reliability; and the possibility of environmentally benign low-noise and low-temperature operation. Unfortunately, while such systems generally have high energy density, their power density is relatively low, as shown in Figure 16. However, a hybrid system combining a fuel cell and storage battery can be designed that has both the high energy density of a fuel cell, as well as the high power density and steady current flow of a storage battery. Such stored energy is also required for control systems, startup, and to enable the system to tolerate fluctuations in fuel, oxidant and load.

\section{Technical Approach}

\section{Concept-of-Operation Sites}

Sizing of the hybrid energy conversion and storage system for each site requires knowledge of the power required to operate the oil and gas production equipment at the site $\left(P_{\text {site }}\right)$, the tie-back distance at the site $\left(T_{\text {site }}\right)$, which determines the length of cable that must be laid for the electrical grid option, and the depth of the site $\left(D_{\text {site }}\right)$, which determines the pressure that the equipment must operate at, as well as the length of air supply line that must be extended to the site from the surface.

\section{Sizing Energy Conversion Device for Each Site}

The weight and volume of an energy conversion system $\left(W_{E C}\right.$ and $\left.V_{E C}\right)$ for a particular site is based upon the total power required by the site $\left(\right.$ Power $\left._{\text {site }}\right)$, the specific power of the energy conversion device $\left(S P_{E C}\right)$, the power density of the device $\left(P D_{E C}\right)$, and the efficiency of the device $\left(\eta_{E C}\right)$.

$$
\begin{gathered}
W_{E C}=\frac{\text { Power }_{\text {site }}}{\eta_{E C} \times S P_{E C}} \\
V_{E C}=\frac{\text { Power }_{\text {site }}}{\eta_{E C} \times P D_{E C}}
\end{gathered}
$$


In some cases, such as the nuclear reactor option, the specific power and power density have been calculated with the device efficiency already accounted for.

$$
\begin{gathered}
W_{E C}=\frac{\text { Power }_{\text {site }}}{S P_{E C-n e t}} \\
V_{E C}=\frac{\text { Power }_{\text {site }}}{P D_{E C-n e t}}
\end{gathered}
$$

The same is true for the options involving the use of thermoelectric generators. The efficiency of the natural gas burning options is accounted for in the adjusted power requirement for the site, as described below.

\section{Adjusted Power Requirements for Site Accounting for Compression of Air from Surface}

Energy conversion systems involving the burning of well head gas must account for: the supply of oxygen, from either high-pressure or cryogenic storage, or from the surface; fueling prior to the availability of well-head gas; possible reforming; gas separation and cleaning technologies up-stream of the fuel cell; pressure envelope design; and interfaces with energy storage, power conditioning, and control systems.

The total power required at the site, including both the equipment required to produce oil from the wells, as well as the compressors required to provide compressed air is:

$$
\text { Power }_{\text {total }}=\text { Power }_{\text {site }}+\text { Power }_{\text {comp }}
$$

The power for compression is proportional to the sum of all gases requiring compression (air, nitrogen, and carbon dioxide) is then:

$$
\text { Power }_{\text {comp }}=\frac{1}{\Delta t} \times f\left(P \ngtr \sum_{i} n_{i}\right.
$$

The function $f(\Delta P) \approx W_{s}$ reflects the energy required for compression of a mole of ideal gas, and the duration $(\Delta t)$ is the period where compression is required. The work involved in the compression of an ideal gas is:

$$
W_{s}=-\Delta H=-c_{p} \boldsymbol{\sigma}_{2}-T_{1}=-R\left(\frac{\kappa}{\kappa-1}\right) T_{1}\left[\left(\frac{P_{2}}{P_{1}}\right)^{(-1) \kappa \kappa}-1\right]
$$

For standard air, the value of $\kappa=1.395$ is recommended for calculations involving moderate temperatures and pressures. In cases involving the reformer-PEMFC combination, the internal combustion engine, or the gas turbine, the total power for the site will be obtained by burning NG from the well head: 


$$
\text { Power }_{\text {total }}=\eta_{\text {total }} \times n_{\text {fuel }} \times \Delta H_{\text {fuel }} \times \frac{1}{\Delta t}
$$

In this case, $\Delta H_{\text {fuel }}$ represents the release of chemical energy from the oxidation of the fuel. The total power for the site, accounting for oil and gas production equipment, as well as the compressors required for the air and exhaust compressors:

$$
\text { Power }_{\text {total }}=\text { Power }_{\text {site }}\left[1-\frac{f \wedge P \times \sum_{i} n_{i}}{\eta_{\text {total }} \times n_{\text {fuel }} \times \Delta H_{\text {fuel }}}\right]^{-1}
$$

In the case of the turbine or internal combustion engine (TIC), the moles of gas requiring compression include the air and exhaust. The exhaust includes both nitrogen, as well as carbon dioxide produced by the combustion.

$$
\sum_{i} n_{i}=n_{\text {air }}+n_{\mathrm{N} 2}+n_{\mathrm{CO}_{2}} \approx n_{\text {fuel }}\left(\frac{1}{0.21}+\frac{0.79}{0.21}+\frac{0.21}{0.21}\right) \approx n_{\text {fuel }}\left(\frac{2}{0.21}\right) \approx 9.524 \times n_{\text {fuel }}
$$

The moles of fuel $\left(n_{\text {fuel }}\right)$ are equivalent to the moles of methane $\left(n_{C H 4}\right)$, and $\Delta H_{\text {fuel }}$ represents the release of chemical energy from the burning of a mole of methane in the internal combustion engine or turbine.

In the case of the reformer-PEMFC system, the moles of gas that require compression are calculated with the following equation:

$$
\sum_{i} n_{i}=n_{\text {air }}+n_{\mathrm{N} 2}+n_{\mathrm{CO}_{2}} \approx n_{\text {fuel }}\left(\frac{1}{2 \times 0.21}+\frac{0.79}{2 \times 0.21}+\frac{1}{4}\right) \approx n_{\text {fuel }}\left(\frac{1.79}{0.42}+0.25\right) \approx 4.512 \times n_{\text {fuel }}
$$

The moles of fuel $\left(n_{\text {fuel }}\right)$ are equivalent to the moles of hydrogen $\left(n_{\mathrm{H} 2}\right)$, and $\Delta H_{\text {fuel }}$ represents the release of chemical energy from the burning of a mole of hydrogen in the PEMFC.

\section{Sizing Energy Storage Device for Each Site}

The weight and volume of an energy storage system $\left(W_{E S}\right.$ and $\left.V_{E S}\right)$ for a particular site is based upon the total power required by the site $\left(P o w e r_{\text {site }}\right)$, the specific energy of the energy storagte device $\left(S E_{E S}\right)$, the energy density of the device $\left(E D_{E S}\right)$, and the efficiency of the device $\left(\eta_{E S}\right)$.

$$
\begin{gathered}
W_{E S}=\frac{\text { Power }_{\text {site }}}{\eta_{E S} \times S E_{E S}} \\
V_{E S}=\frac{\text { Power }_{\text {site }}}{\eta_{E S} \times E D_{E S}}
\end{gathered}
$$

\section{Pressure Vessel Design}

The following semi-empirical relationships have been developed to predict the critical pressure for ringstiffened cylindrical vessels, designed to enclose the hybrid energy conversion and storage system, and 
capable of withstanding external pressurization at a particular sites depth. The equation for the buckling pressure is:

$$
P_{C R}=S_{y} Z_{1} \boldsymbol{\ell}_{2}-n Z_{3}^{-}
$$

The parameter $\mathrm{S}_{\mathrm{y}}$ is the yield strength of the material, $\mathrm{n}(=\mathrm{e} / \mathrm{t})$ is the ratio of radial deviation to thickness (out-of-roundness), and $Z_{1}, Z_{2}$ and $Z_{3}$ are collapse pressure formula parameters.

$$
\begin{aligned}
& Z_{1}=\exp \left(-\frac{0.815 m^{1 / 2}}{k \phi}\right) \\
& Z_{2}=\frac{1}{m^{0.95} \leftarrow \phi_{-}^{0.10}} \\
& Z_{2}=\frac{50}{m^{1.95} \phi^{\gamma+10}}-\frac{33}{m^{2}}
\end{aligned}
$$

The parameter $m(=r / t)$ is the ratio of the mean radius to the thickness, $k(=t / h)$ is the thickness to length ratio, and $\phi\left(=E / S_{y}\right)$ is the inverse strain parameter.

$$
\begin{aligned}
& 0 \leq n \leq \frac{m}{100} \\
& 10 \leq m \leq 100 \\
& 0.001 \leq k \leq 0.200 \\
& 100 \leq \phi \leq 1000
\end{aligned}
$$

\section{Capital Investment at Commencement of Commercial Operations}

The cost of an electrical grid on the ocean floor is used as the basis of comparison. Based upon oil company estimates, it is assumed that such a cable will cost approximately $\$ 2.5$ million per kilometer. The tie-back distance is multiplied by this cost to give an estimate of the total cable cost for a given site. It is further assumed that the cost of one $40 \mathrm{MW}$ substation on the ocean floor is approximately $\$ 30$ million, with the number of stations determined from the total power required for the site, and with a minimum of one substation per site.

In regard to the hybrid power systems, the total cost of an energy conversion system is estimated from the total power for the site, and the power-specific cost $\left(P S C_{E C}\right)$ :

$$
\text { Cost }_{E C}=\text { Power }_{\text {Site }} \times P S C_{E C}
$$

The total cost of an energy conversion system is estimated from the total power for the site, and the power-specific cost $\left(E S C_{E S}\right)$ : 


$$
\text { Cost }_{E C}=\text { Power }_{\text {Site }} \times E S C_{E S}
$$

The cost for the pressure vessel is calculated from the total weight of the vessel $\left(W_{P V}\right)$ is calculated with the following generalized expression [Peters et al.]:

$$
\operatorname{Cost}_{P V}=A_{P V} \times V_{P V}{ }^{-\alpha}
$$

The constants $A_{P V} \approx 73 \$ / \mathrm{kg}$-steel and $\alpha_{P V} \approx-0.34$ are materials-specific constants for steel, and $B_{P V} \approx 11$ \$-titanium/\$-steel is an allowance factor used to account for more expensive materials of construction, such as titanium-based alloys. It is assumed that a protective steel hull structure is built around the pressure vessel, with a weight roughly equivalent to the weight of the pressure vessel, and with a cost factors provided by the oil and gas industry:

$$
\operatorname{Cost}_{P V \text {-total }}=A_{P V} \times B_{P V} \times\left(V_{P V}\right)^{\lambda_{P V}}+\widehat{C}_{\text {hull }} \times W_{P V} \ni D_{\text {hull }}
$$

The hull cost parameters are: $C_{\text {hull }} \approx \$ 8 / \mathrm{kg}$-steel and $D_{\text {hull }} \approx \$ 15$ million. The volume of the flotation tank is designed to enable enough water displacement to float the entire hybrid power system, accounting for the weights of the energy conversion device, the energy storage device, the pressure vessels, and the floatation tank. The wall thickness of the floatation tank is designed to prevent collapse at depth, using the same critical wall thickness formulae used to design the pressure vessels. Furthermore, the same cost correlation is used to estimate the cost of the floatation tank.

$$
\left.\operatorname{Cost}_{F T}=A_{F T} \times V_{F T}\right)^{-\gamma_{F T}}
$$

A protective hull structure is also assumed around the floatation tanks.

$$
\operatorname{Cost}_{F T-\text { total }}=A_{F T} \times B_{F T} \times \mathbb{V}_{F T} \boldsymbol{\gamma}_{F T}+\boldsymbol{C}_{\text {hull }} \times W_{F T} \ngtr D_{\text {hull }}
$$

The total direct cost (Cost direct $_{\text {) }}$ for the energy conversion and storage components, the pressure vessel, the floatation tanks, and the protective hulls is calculated as follows:

$$
\operatorname{Cost}_{\text {direct }}=\operatorname{Cost}_{E C}+\operatorname{Cost}_{E S}+\operatorname{Cost}_{P V-\text { total }}+\operatorname{Cost}_{F T-\text { total }}
$$

Indirect cost factors $(I D F S)$ are applied to the total direct cost to account for indirect costs, including: (1) construction services $\approx 10$ percent; ( 2 ) home office engineering and services $\approx 7$ percent; (3) field office engineering and services $\approx 5$ percent; $(4)$ owner's costs $\approx 13$ percent; and (5) non-NRC licensing and permitting $\approx 1$ percent.

$$
\operatorname{Cost}_{\text {indirect }}=\operatorname{Cost}_{\text {direct }} \times \sum_{i} I D F_{i}
$$

A contingency allowance of $\sim 10 \%$ and an allowance for miscellaneous costs $\sim 1 \%$ are included to calculate the total overnight cost. These are accounted for in the allowance factors (AFs). 
$\operatorname{Cost}_{\text {overnight }}=\operatorname{Cost}_{\text {direct }} \times\left(1+\sum_{i} I D F_{i}\right) \times\left(1+\sum_{j} A F_{j}\right)$

A construction escalation allowance of $\sim 5 \%$ and an allowance for interest of $\sim 5 \%$ are included to calculate the cost at the commencement of commercial operations. These are accounted for in the allowance factors $(E F s)$.

$\operatorname{Cost}_{\text {total }}=\operatorname{Cost}_{\text {direct }} \times\left(1+\sum_{i} I D F_{i}\right) \times\left(1+\sum_{j} A F_{j}\right) \times\left(1+\sum_{k} E F_{k}\right)$

\section{$\underline{\text { Annualized Cost at Commencement of Commercial Operations }}$}

The annualized cost at the commencement of commercial operations is calculated by applying the annuity present worth factor to the total direct and indirect costs $\left(A_{P F} \approx 9.63 \%\right.$ at an optimistic discount rate of approximately $5 \%$, which is customary for projects of relatively low risk). In regard to the calculation of the annualized costs, the compound interest factor $\left(f_{i}\right)$ is:

$f_{i}=\mathbf{1}^{i} i^{\pi}$

The discount factor $\left(f_{d}\right)$ is then:

$f_{d}=\frac{1}{f_{i}}$

The annuity future worth factor $\left(f_{A F}\right)$ is:

$f_{A F}=\frac{A}{F}=\frac{i}{\left(+i^{\pi}-1\right.}$

The parameter $i$ is the interest rate, the parameter $\mathrm{n}$ is the number of payment periods, $A$ is the annuity, or annualized cost, and the parameter $\mathrm{F}$ is the future worth of the money. The annuity present worth factor $\left(f_{A P}\right)$ is:

$f_{A P}=\frac{A}{P}=\frac{i i^{\pi}}{\mathbf{Q}_{+}+i_{-}^{\pi}-1}$

The parameter $P$ is the present value of the money. Using this formalism, the total annualized cost $(A \approx$ Cost $\left._{\text {annualized }}\right)$ is then calculated from the cost at the commencement of commercial operations (Cost total $_{\text {) }}$ as follows:

Cost $_{\text {annualized }}=$ Cost $_{\text {total }} \times f_{A P}$

Assumed values used for the economic analysis are summarized in the appendices (Appendix $\mathrm{H}$, Tables $\mathrm{H} 1$ through $\mathrm{H} 5$ ). 


\section{Annual Operating Expense}

Several contributions to annual operating and maintenance costs are accounted for by applying appropriate factors to the annualized cost at the commencement of commercial operations. These contributions include: (1) chemicals, materials and utilities $\approx 10$ percent; ( 2 ) spare parts and capital plant upgrades $\approx 10$ percent; ( 3 ) taxes and insurance $\approx 10$ percent; (4) operating cost contingency $\approx 5$ percent; (4) general operating and maintenance costs $\approx 2$ percent; and (5) miscellaneous operating and maintenance costs $\approx 1$ percent; and are accounted for in operation and maintenance factors (OPFs).

Cost $_{\text {operations }}=$ Cost $_{\text {annualized }} \times \sum_{i} O P F_{i}$

\section{Cost of Electricity}

The total annual cost of operation is:

Cost $_{\text {annualtotal }}=$ Cost $_{\text {annualized }}+$ Cost $_{\text {operations }}=\operatorname{Cost}_{\text {annualized }}\left(1+\sum_{i} O P F_{i}\right)$

The cost of electricity $(C O E)$ is then calculated by dividing the total annualized cost by the energy generated.

COE $=\frac{\text { Cost }_{\text {annual total }} \text { ) }}{\text { Power }_{\text {total }} \times \mathbf{Q} 4 \times 365 \text { hours } / \text { year }}$

These formulae have been used to predict the cost-of-electricity from each of the hybrid options, for each of the concept-of-operations sites. The results are summarized in the following section.

\section{Results}

Weight of Energy Conversion and Storage Components for Each Site

The estimated weights of the energy conversion and storage components for each hybrid system, evaluated for each concept-of-operations site are summarized in Table 5 and Figure 1, with more detail presented in the appendices (Appendix I).

\section{Total Weight of Hybrid System for Each Site}

The estimated total weight for each hybrid system, evaluated for each concept-of-operations site are summarized in Table 5 and Figure 2, with more detail presented in the appendices (Appendix I). The weight of the hybrid energy conversion and storage systems for the three largest sites, Shtokman, Chinook and Ormen Lange, are between 10,000 and 100,000 metric tons. For comparison, the NS Savannah and NS Otto Hahn weighed 25,790 and 22,000 metric tons, respectively. Thus, the largest hybrid systems will have weights comparable to these nuclear powered ships. 


\section{Total Volume of Hybrid System for Each Site}

The estimated total volume for each hybrid system, evaluated for each concept-of-operations site are summarized in Table 5 and Figure 3, with more detail presented in the appendices (Appendix I). While the hybrid systems are comparable to the commercial nuclear-powered ships in weight, their density is greater, so they occupy less volume than the ships.

\section{Capital Investment at Commencement of Commercial Operations}

The estimated capital investment at the commencement of commercial operations for each hybrid system, evaluated for each concept-of-operations site are summarized in Table 6 and Figure 4, with more detail presented in the appendices (Appendix I). The capital costs are dominated by parameters that are insensitive to the size of the site, such as those used to account for the assumed protective hull, and are relatively insensitive to the size of the site. The subsea vehicular options are the most expensive and least practical. The subsea vehicle that ferries stored energy from the surface to the site via batteries is by far the worst option, and is not given any serious consideration.

\section{Annualized Cost at Commencement of Commercial Operations}

The estimated annualized cost at the commencement of commercial operations for each hybrid system, evaluated for each concept-of-operations site are summarized in Table 6 and Figure 5, with more detail presented in the appendices (Appendix I). Like the initial capital cost, the annualized costs are dominated by parameters that are insensitive to the size of the site, and are also insensitive to the size of the site.

\section{Cost of Electricity}

The estimated cost of electricity (COE) for each hybrid system, evaluated for each concept-of-operations site are summarized in Table 6 and Figure 6, with more detail presented in the appendices (Appendix I). The least expensive option for power at all of the concept-of-operations sites is the electrical grid, with an assumed cost of approximately $\$ 2.5$ million per kilometer. In regard to the COE, hybrid power options that are comparable with the grid option include the pressurized water reactor (PWR), a fuel cell on the ocean floor fueled with well-head methane and a line to the surface for compressed air (FC1), or a fuel cell on the ocean floor fueled with well-head methane and oxygen brought to the system in submersible tanks (FC2). The team prefers FC1 since FC2 seems impractical from an operational pointof-view.

\section{Economy of Scale}

The estimated cost of electricity (COE) as a function of power generation capacity is shown in Figure 7, and shows a clear economy of scale. As the systems become larger, the cost of electricity produced by the system becomes less expensive, regardless of the hybrid system assumed. The two largest sites, Shtokman and Ormen Lange are off sufficient size so that power can be supplied for less than \$1 per kilowatt-hour, comparable to the cost for grid power. 


\section{Summary}

An investment in deep-sea (deep-ocean) hybrid power systems may enable certain off-shore oil and gas exploration and production. Advanced deep-ocean drilling and production operations, locally powered, may provide commercial access to oil and gas reserves otherwise inaccessible. Further, subsea generation of electrical power has the potential of featuring a low carbon output resulting in improved environmental conditions. Such technology therefore, enhances the energy security of the United States in a green and environmentally friendly manner. The objective of this study is to evaluate alternatives and recommend equipment to develop into hybrid energy conversion and storage systems for deep ocean operations. Such power systems will be located on the ocean floor and will be used to power offshore oil and gas exploration and production operations. Such power systems will be located on the oceans floor, and will be used to supply oil and gas exploration activities, as well as drilling operations required to harvest petroleum reserves. The following conceptual hybrid systems have been identified as candidates for powering sub-surface oil and gas production operations:

1. $P W R=$ Pressurized-Water Nuclear Reactor + Lead-Acid Battery

2. $\mathrm{FC1}=$ Line for Surface $\mathrm{O}_{2}+$ Well Head Gas + Reformer + PEMFC + Lead-Acid \& Li-lon Batteries

3. $\mathrm{FC2}=$ Stored $\mathrm{O} 2+$ Well Head Gas + Reformer + Fuel Cell + Lead-Acid \& Li-Ion Batteries

4. $\mathrm{SV} 1=$ Submersible Vehicle + Stored $\mathrm{O}_{2}+$ Fuel Cell + Lead-Acid $\&$ Li-Ion Batteries

5. $\mathrm{SV} 2=$ Submersible Vehicle + Stored $\mathrm{O}_{2}+$ Engine or Turbine + Lead-Acid $\&$ Li-Ion Batteries

6. SV3 $=$ Submersible Vehicle + Charge at Docking Station + ZEBRA \& Li-lon Batteries

7. $P W R T E G=P W R+$ Thermoelectric Generator + Lead-Acid Battery

8. WELL TEG $=$ Thermoelectric Generator + Well Head Waste Heat + Lead-Acid Battery

9. GRID = Ocean Floor Electrical Grid + Lead-Acid Battery

10. DOC $=$ Deep Ocean Current + Lead-Acid Battery

Detailed analyses of each of the eight leading hybrid options, as well as the assumed base case (ocean floor electrical grid) are given in Appendix F. The deep ocean current option was abandoned early, due to the low velocities on the floor of the ocean (less than 0.5 meters per second), and the very large turbine size that would be required with such low velocities (300-foot span).

The weight of the hybrid energy conversion and storage systems for the three largest sites, Shtokman, Chinook and Ormen Lange, are between 10,000 and 100,000 metric tons. For comparison, the NS Savannah and NS Otto Hahn weighed 25,790 and 22,000 metric tons, respectively. Thus, the largest hybrid systems will have weights comparable to these nuclear powered ships. While the hybrid systems are comparable to the commercial nuclear-powered ships in weight, their density is greater, so they occupy less volume than the ships. The capital costs are dominated by parameters that are insensitive to the size of the site, such as those used to account for the assumed protective hull, and are relatively insensitive to the size of the site. The subsea vehicular options are the most expensive and least practical. The subsea vehicle that ferries stored energy from the surface to the site via batteries is by far the worst option, and is not given any serious consideration. Like the initial capital cost, the annualized costs are dominated by parameters that are insensitive to the size of the site, and are also insensitive to the size of the site. The least expensive option for power at all of the concept-of-operations sites is the 
electrical grid, with an assumed cost of approximately $\$ 2.5$ million per kilometer. In regard to the COE, hybrid power options that are considered to be comparable with the grid option are the pressurized water reactor (PWR) and a fuel cell on the ocean floor fueled with well-head methane and a line to the surface for compressed air (FC1). As the systems become larger, the cost of electricity produced by the system becomes less expensive, regardless of the hybrid system assumed. The two largest sites, Shtokman and Ormen Lange are off sufficient size so that power can be supplied for less than $\$ 1$ per kilowatt-hour, comparable to the cost for grid power.

\section{References}

Keith Adendorff, First National Battery, Batteries for Energy Storage (www.battery.co.za), ZEBRA Battery (www.cebi.com), Downloaded August 12, 2009, 40 Slides.

Allen J. Bard, Larry R. Faulkner, Electrochemical Methods, Fundamentals and Applications, Selected Standard Electrode Potentials in Aqueous Solutions at 25]C in V vs. NHE, Table C.1, Appendix C, John Wiley \& Sons, New York, New York, 1980, pp. 699-701.

Alexander Blake, External Pressure, Chapter 36, Practical Stress Analysis in Engineering Design, $2^{\text {nd }}$ Edition, Revised and Expanded, Marcel Dekker, Incorporated, New York, New York and Basel, Switzerland, Equations 36.20 through 36.23, pp. 513-545.

Jeffrey W. Braithwaite, William L. Auzer, Sodium Beta Bateries, Chapter 40, Handbook of Batteries, 2nd Edition, David Linden, Thomas B. Reddy, Editors, McGraw-Hill, San Francisco, California, 1995, pp. 40.1 through 40.32 .

Jeffrey W. Braithwaite, William L. Auzer, Sodium Beta Batteries, Chapter 40, Handbook of Batteries, 3rd Edition, David Linden, Thomas B. Reddy, Editors, McGraw-Hill, San Francisco, California, 2002, pp. 40.1 through 40.31 .

Cord-H. Dustmann, ZEBRA Battery Meets USABC Goals, Journal of Power Sources, Volume 72 Issue 1, March 30, 1998, Pages 27-31.

Cord-H. Dustmann, The Swiss ZEBRA Battery System, Presented at EVS-17, Pages 1-17.

K. Fukuda, W. Danker, J. S. Lee, A. Bonne, M. J. Crijns, IAEA Overview of Global Spent Fuel Storage, IAEA-CN-102/60, Department of Energy, International Atomic Energy Agency, Vienna, Austria, Table I.

Doris L. Gonzalez, Abul K. M. Jamaluddin, Schlumberger; Trond Solbakken, Hydro Gulf of Mexico; George J. Hirasaki, Walter G. Chapman, Rice Univesity, Impact of Flow Assurance in the Development of a Deepwater Prospect, SPE 110833, Society of Petroleum Engineers, Incorporated, 10 pages.

Tyler Hamilton, Senior Energy Reporter and Columnist, Toronto Star Newspaper, Canada 
Ronald O. Hammel, Alvin J. Salkind, David Linden, Sealed Lead-Acid Batteries, Chapter 25, Handbook of Batteries, 2nd Edition, David Linden, Editor, McGraw-Hill, San Francisco, California, 1995, pp. 25.1 through 25.39 .

Rich Haut, Deep Sea Hybrid Power Systems, Functional Requirements, Basis of Design, Houston Advanced Research Center, Houston, TX, Subcontract 07121-1902, 2009, 7 pages; Source: 2008 Worldwide Survey of Subsea Processing, Separation, Compresion, and Pumping Systems.

Sohrab Houssain, Rechargeable Lithium Batteries, Ambient Temperature, Chapter 36, Handbook of Batteries, 2nd Edition, David Linden, Thomas B. Reddy, Editors, McGraw-Hill, San Francisco, California, 1995, pp. 36.1 through 36.77.

Makoto Kamibayashi, Advanced Sodium-Sulfure (NAS) Battery System, Tokoyo Electric Power Company (TEPCO), Tokoyo, Japan, Downloaded August 12, 2009, 19 Slides.

Ramesh Kainthla, Ph.D., Brendan Coffey, Ph.D., RBC Technologies, NASA Aerospace Workshop, Huntsville, AL, Long Life, High Energy Silver/Zinc Batteries, 11/19/2002.

Alexander P. Karpinski, Stephen F. Schiffer, Peter A. Karpinski, Silver Oxide Batteries, Chapter 33, Handbook of Batteries, 3rd Edition, David Linden, Thomas B. Reddy, Editors, McGraw-Hill, San Francisco, California, 2002, pp. 33.1 through 33.30.

A. P. Karpinski, S. J. Russell, J. R. Serenyi, J. P. Murphy, Silver Based Batteries for High Power Applications, Journal of Power Sources, Volume 91, 2000, pp. 77-82.

Edwin C. Kluiters, Dick Schmal, Willem R. ter Veen, Kees J. C. M. Posthumus, Testing of a Sodium/Nickel Chloride (ZEBRA) Battery for Electric Propulsion of Ships and Vehicles, Journal of Power Sources, Volume 80, Issues 1-2, July 1999, Pages 261-264.

David Linden, Sealed Lead-Acid Batteries, Chapter 23, Handbook of Batteries, 2nd Edition, David Linden, Editor, McGraw-Hill, San Francisco, California, 1995, pp. 23.1 through 23.22.

MES-DEA S. A., Divisione Energie Alternative, Via Laveggio, 15 CH-6855 Stabio, Switzerland, Tel. 41 (0) 91 6415392, Fax. 41 (0) 91 6415395, Email. info@mes-dea.ch, Internet www.mes-dea.ch

Benjamin L . Norris, Jeff Newmiller, Georgianne Peek, NAS Battery Demonstration at American Electric Power, A Study for the DOE energy Storage Program, Report SAND2006-6740, Sandia National Laboratory, Albuquerque, New Mexico 87185, Livermore, California 94550, March 2007, 55 Pages.

Perry's Chemical Engineering Handbook, $7^{\text {th }}$ Edition, McGraw Hill, San Francisco, CA, pp. 9-10 to 9-13. Max Peters, Klaus Timmerhaus, Robert West, Plant Design and Economics, 5th Edition, Chapter 12, 2008, p. 553.

Technology Insights, Overview of NAS Battery for Load Management, California Energy Storage Workshop, February 2005, 22 Pages. 
Rebecca Smith, Small Reactors Generate Big Hopes, The Wall Street Journal, Vol. CCLV, No. 39, Thursday, February 18, 2010, p. A1, A16.

T. M. O'Sullivan, C. M. Bingham, R. E. Clark, Zebra Battery Technologies for All Electric Smart Car, Department of Electronic \& Electrical Engineering, University of Sheffield, SPEEDAM 2006. International Symposium on Power Electronics, Electrical Drives, Automation and Motion, Taormina, May 23-26, 2006, Published July 5, 2006, IEEE Xplore, Page S34-6 through S34-11.

Sacramento Municipal Utility District Electric Transportation Department (SMUD), Electric School Bust with ZEBRA Battery and Integrated Fast Charge, FCalifornia Air Resources Board, ICAT Grant \#01-1, Final Technical report, April 30, 2004, Pages 1-37; Table 1, Battery Technology Comparison, Page 7; Table 2, Component Costs for the Prototype Bus, Page 11; Table 3, Life Cycle Cost Input Data, Page 12.

Alvin J. Salkind, John J. Kelly, Anthony G. Cannone, Lead-Acid Batteries, Chapter 24, Handbook of Batteries, 2nd Edition, David Linden, Editor, McGraw-Hill, San Francisco, California, 1995, pp. 24.1 through 25.89 .

Stephen F. Schiffer, Peter A. Karpinski, Silver Oxide Batteries, Chapter 31, Handbook of Batteries, 2nd Edition, David Linden, Editor, McGraw-Hill, San Francisco, California, 1995, pp. 31.1 through 31.28.

R. A. A. Schillemans, C.E. Kluiters, Sodium/Sulphur Batteries for Naval Applications, Power Sources 15, A. Attewell and T. Keily, Editors, International Power Sources Symposium Committee, Crowborough UK, 1995 p. 421.

Leslie Smart, Elaine Moore, Solid Electrolytes, Section 5.4, Defects and Non-Stoichiometry, Chapter 5, Solid State Chemistry, 2nd Edition, Stanley Thornes Publishers Ltd., Cheltenham, United Kingdom, 1998, p. 172-184.

Peter A. Thornton, Vito J. Colangelo, Strengthening Mechanisms \& Responst to Thermal Treatment, Chapter 6, Fundamentals of Materials Science, Prentice-Hall, Englewood Cliffs, NJ, 1985, p. 134-168: Table 6-1, Elastic Properties for Selected Engineering Materials at Room Temperature, p. 144.

Dave Willamson, Neil Benstead, The Installation and Use of ZEBRA Batteries, Submarine and ASW Asia 2006, Defense Directory Com Conferences, 2006.

Warren C. Young, Shells of Revolution, Prssure Vessels, Pipes, Chapter 12, Roark's Formulas for Stress and Strain, 6th Edition, McGraw-Hill, San Francisco, CA, 1989, pp. 515-646: Table 32 - Case 1c \& 1d Uniform external radial pressure q; longitudninal pressure zero or externally balanced \& ends capped; for a disk or a shell. 


\section{Acknowledgements}

This work was performed under the auspices of the U.S. Department of Energy by Lawrence Livermore National Laboratory under Contract DE-AC52-07NA27344. Work was co-sponsored by the Research Partnership for an Energy Secure America (RPSEA). 


\section{Tables}

Table 1 - Concept-of-operations sites for evaluation of deep ocean hybrid power systems [Haut 2009]

\begin{tabular}{|l|l|l|r|r|r|r|r|r|r|}
\hline Field or Project & Owner & Region & Year & Depth & Depth & Tie Back & Tie Back & Total \\
\hline name & & & calendar & meters & feet & $\mathrm{km}$ & miles & MBOPD & Pow \\
\hline Shtokman & Gazprorn & Barents Sea & 2020 & 350 & 1,148 & 565.0 & 209.0 & $\mathrm{NA}$ & 240.0 \\
\hline Chinook & Petrobras & GOM & 2009 & 2,682 & 8,800 & 19.3 & 12.0 & 20 & 7.2 \\
\hline King & BP & GOM & 2007 & 1,700 & 5,578 & 20.0 & 18.0 & 83 & 2.0 \\
\hline Ormen Lange & Hydro & Norway & 2011 & 850 & 2,789 & 120.0 & 193.0 & 79 & 60.0 \\
\hline Perdido & Shell & GOM & 2010 & 2,438 & 7,999 & $\mathrm{NA}$ & $\mathrm{NA}$ & 40 & 5.0 \\
\hline Argonauta & Shell & Brazil & 2009 & 1,900 & 6,234 & 9.0 & 5.6 & 9.7 & 2.2 \\
\hline Marimba Field & Petrobras & Campros Basin & 2000 & 395 & 1,296 & 1.1 & 0.7 & 7 & 0.1 \\
\hline Pazflor & Total & Angola Blk 17 & 2011 & 800 & 2,625 & 4.0 & 3.0 & $\mathrm{NA}$ & 13.8 \\
\hline Hypothetical & & & 1,389 & 4,559 & 105.5 & 63.0 & & 41.3 \\
\hline & & & & & & & & \\
\hline
\end{tabular}

Table 2 - Summary of deep ocean hybrid generation and storage options considered for study

\begin{tabular}{|l|r|}
\hline Description & Nomenclature \\
\hline PWR $=$ Nuclear Reactor + Pb Acid Battery & PWR \\
\hline FC1 = Line for Surface O2 + WELL Head Gas + Reformer + PEMFC + Battery & FC1 \\
\hline FC2 $=$ Stored O2 + Well Head Gas + Reformer + Fuel Cell + Battery & FC2 \\
\hline SV1 = Submersible Vehicle + Stored O2 + Fuel Cell + Battery & SV1 \\
\hline SV2 = Submersible Vehicle + Stored O2 + Engine or Turbine + Battery & SV2 \\
\hline SV3 = Submersible Vehicle + Charge at Docking Station + ZEBRA Battery & SV3 \\
\hline PWR TEG = PWR + WELL TEG + Pb Acid Battery & PWR TEG \\
\hline WELL TEG = Thermoelectric Generator + Well Head Waste Heat + Battery & WELL TEG \\
\hline GRID = Floor Electrical Grid + Battery & GRID \\
\hline DOC = Deep Ocean Current + Battery & DOC \\
\hline
\end{tabular}

Table 3 - Summary of key attributes of power generation options used to assess hybrid system options

\begin{tabular}{|l|l|r|r|r|r|}
\hline Screening Criteria & Units & PWR & FC & TIC & TEG \\
\hline Specific Power & W/kg & 250.0 & 28.90 & 1057 & 8.800 \\
\hline Power Density & W/L & 791.6 & 20.78 & 3347 & 2.200 \\
\hline Specific Energy & Wh/kg & $10,950,000$ & & & \\
\hline Energy Density & Wh/L & $34,672,967$ & & & \\
\hline Overall Device Efficiency & $\%$ & 0.30 & 0.60 & 0.40 & 0.10 \\
\hline Technology Cost & \$/kW & 7,500 & 2,500 & 500 & 2,000 \\
\hline
\end{tabular}

Table 4 - Summary of key attributes of energy storage options used to assess hybrid system options

\begin{tabular}{|l|l|r|r|r|r|r|r|}
\hline Screening Criteria & Units & Pb Acid & AgZn & NaS & ZEBRAA & Li-Ion & Regen FC \\
\hline Specific Power & W/kg & 20 & 1470 & 250 & 169 & 74 & 27 \\
\hline Power Density & W/L & 51 & 2520 & 386 & 261 & 147 & 17 \\
\hline Specific Energy & Wh/kg & 20 & 105 & 117 & 94 & 75 & 326 \\
\hline Energy Density & Wh/L & 50 & 180 & 147 & 148 & 139 & 209 \\
\hline Coulombic Efficiency (Ah/Ah) & $\%$ & 0.80 & 0.90 & 0.89 & 1.00 & 0.99 & 0.90 \\
\hline Electrical Efficiency (Wh/Wh) & $\%$ & 0.70 & 0.75 & 0.70 & 0.70 & 0.95 & 0.43 \\
\hline Overall Device Efficiency & $\%$ & 0.56 & 0.68 & 0.62 & 0.70 & 0.94 & 0.38 \\
\hline Technology Cost & $\$ / k W h$ & 150 & 600 & 300 & 220 & 300 & 5000 \\
\hline
\end{tabular}


Table 5-Summary of the predicted mass and volume of deep ocean hybrid power generation and energy storage options, for each of the con-ops cases

\begin{tabular}{|c|c|c|c|c|c|c|c|c|c|}
\hline \multicolumn{10}{|c|}{ Hybrid System Volume (Cubic Meters) } \\
\hline Site & PWR & $\mathrm{FC} 1$ & $\mathrm{FC} 2$ & SV1 & SV2 & SV3 & PWR TEG & WELLL TEG & GRID \\
\hline Shtokman & 89,574 & 185,132 & $21,126,191$ & $52,815,478$ & $42,795,786$ & $2,433,210$ & 324,766 & 323,145 & 92,534 \\
\hline Chinook & 3,139 & 71,237 & $7,785,692$ & $19,464,230$ & $8,429,285$ & 88,712 & 12,455 & 12,397 & 3,238 \\
\hline King & 840 & 4,642 & 524,414 & $1,311,036$ & 921,613 & 23,442 & 3,190 & 3,174 & 986 \\
\hline Ormen Lange & 24,027 & 69,480 & $7,953,368$ & $19,883,421$ & $15,506,951$ & 661,517 & 87,782 & 87,332 & 24,551 \\
\hline Perdido & 2,112 & 28,999 & $3,202,843$ & $8,007,107$ & $4,370,490$ & 59,280 & 8,313 & 8,275 & 2,231 \\
\hline Argonauta & 943 & 6,236 & 699,846 & $1,749,614$ & $1,179,736$ & 26,442 & 3,608 & 3,590 & 998 \\
\hline Marimba Field & 30 & 64 & 7,343 & 18,358 & 14,827 & 817 & 109 & 108 & 38 \\
\hline Pazflor & 5,167 & 15,204 & $1,760,846$ & $4,402,115$ & $3,447,586$ & 140,892 & 19,216 & 19,124 & 5,108 \\
\hline \multicolumn{10}{|c|}{ Hybrid System Weight (Metric Tons) } \\
\hline Site & PWR & $F C 1$ & $\mathrm{FC2}$ & SV1 & SV2 & $\mathrm{SV} 3$ & PWR TEG & WELLL TEG & GRID \\
\hline Shtokman & 56,163 & 67,923 & 86,641 & 216,603 & 136,060 & $1,237,266$ & 95,306 & 94,222 & 95,938 \\
\hline Chinook & 3,476 & 54,517 & 45,989 & 114,973 & 24,922 & 85,544 & 9,018 & 8,951 & 4,805 \\
\hline King & 736 & 2,668 & 2,650 & 6,625 & 2,815 & 17,451 & 1,654 & 1,640 & 2,169 \\
\hline Ormen Lange & 16,837 & 30,173 & 34,832 & 87,081 & 47,791 & 382,404 & 32,145 & 31,818 & 25,188 \\
\hline \begin{tabular}{|l|} 
Perdido \\
\end{tabular} & 2,231 & 20,740 & 18,208 & 45,521 & 13,049 & 54,117 & 5,567 & 5,525 & 3,584 \\
\hline Argonauta & 865 & 3,810 & 3,659 & 9,148 & 3,597 & 20,723 & 2,013 & 1,996 & 1,499 \\
\hline Marimba Field & 19 & 24 & 30 & 76 & 47 & 420 & 33 & 32 & 98 \\
\hline \begin{tabular}{|l|} 
Pazflor \\
\end{tabular} & 3,732 & 6,527 & 7,612 & 19,030 & 10,567 & 83,903 & 7,001 & 6,929 & 3,950 \\
\hline \multicolumn{10}{|c|}{ Energy Conversion \& Storage Components (Metric Tons) } \\
\hline Site & PWR & $\mathrm{FC1}$ & $\mathrm{FC2}$ & SV1 & SV2 & SV3 & PWR TEG & WELL TEG & GRID \\
\hline Shtokman & 49,600 & 56,866 & 47,096 & 117,740 & 64,762 & $1,072,340$ & 76,873 & 75,913 & 89,499 \\
\hline Chinook & 1,488 & 16,447 & 8,375 & 20,937 & 2,023 & 32,170 & 2,306 & 2,277 & 2,855 \\
\hline King & 413 & 1,192 & 732 & 1,829 & 546 & 8,936 & 641 & 633 & 1,852 \\
\hline Ormen Lange & 12,400 & 19,723 & 14,375 & 35,937 & 16,244 & 268,085 & 19,218 & 18,978 & 20,838 \\
\hline \begin{tabular}{|l|} 
Perdido \\
\end{tabular} & 1,033 & 6,879 & 3,671 & 9,176 & 1,388 & 22,340 & 1,602 & 1,582 & 2,409 \\
\hline Argonauta & 455 & 1,565 & 924 & 2,311 & 602 & 9,830 & 705 & 696 & 1,097 \\
\hline Marimba Field & 17 & 20 & 16 & 40 & 22 & 357 & 26 & 25 & 96 \\
\hline Pazflor & 2,852 & 4,396 & 3,240 & 8,099 & 3,735 & 61,660 & 4,420 & 4,365 & 3,086 \\
\hline
\end{tabular}

Table 6 - Summary of the cost-of-electricity, annualized costs and capital investment for each of the deep ocean hybrid power generation and energy storage options, for each of the con-ops cases

\begin{tabular}{|c|c|c|c|c|c|c|c|c|c|}
\hline \multicolumn{10}{|c|}{ Cost of Electricity at Site (\$/kWh-e) } \\
\hline Site & PWR & FC1 & $\mathrm{FC} 2$ & SV1 & SV2 & $\mathrm{SV}_{3}$ & PWR TEG & WELLL TEG & GRID \\
\hline Shtokman & 0.3117 & 0.4718 & 0.3986 & 0.9950 & 0.4541 & 5.9075 & 0.4084 & 0.1861 & 0.2565 \\
\hline Chinook & 3.5520 & 8.7727 & 6.2999 & 15.6973 & 8.8381 & 116.1483 & 4.8741 & 3.5773 & 2.5289 \\
\hline King & 11.9500 & 12.9326 & 12.3294 & 30.6352 & 29.0088 & 402.2488 & 15.9392 & 11.7736 & 8.7918 \\
\hline Ormen Lange & 0.6199 & 0.9691 & 0.8028 & 2.0007 & 1.2261 & 16.3595 & 0.8406 & 0.5183 & 0.4424 \\
\hline Perdido & 4.9707 & 7.9399 & 6.5002 & 16.1753 & 12.1636 & 164.4874 & 6.7352 & 4.9529 & 4.5988 \\
\hline Argonauta & 10.8993 & 12.1912 & 11.4536 & 28.4629 & 26.4802 & 366.4688 & 14.5651 & 10.7602 & 7.6954 \\
\hline Marimba Field & 291.6057 & 287.7732 & 286.8783 & 712.4901 & 711.8591 & 9924.6266 & 386.1943 & 286.6950 & 202.4166 \\
\hline Pazflor & 1.9239 & 2.2439 & 2.0803 & 5.1735 & 4.4147 & 60.7853 & 2.5704 & 1.8045 & 1.2310 \\
\hline \multicolumn{10}{|c|}{ Annualized Costs (\$M) } \\
\hline \begin{tabular}{|l} 
Site \\
\end{tabular} & PWR & $\mathrm{FC1}$ & $\mathrm{FC2}$ & SV1 & SV2 & SV3 & PWR TEG & WELLL TEG & GRID \\
\hline Shtokman & 655.8413 & 992.6223 & 838.6570 & 2093.3426 & 955.4366 & 12428.4891 & 859.3045 & 391.5581 & 539.6797 \\
\hline Chinook & 224.1873 & 553.6930 & 397.6164 & 990.7410 & 557.8189 & 7330.7225 & 307.6329 & 225.7816 & 159.6117 \\
\hline King & 209.5081 & 226.7335 & 216.1588 & 537.0969 & 508.5824 & 7052.2254 & 279.4467 & 206.4147 & 154.1381 \\
\hline Ormen Lange & 326.0484 & 509.7039 & 422.2295 & 1052.2736 & 644.8546 & 8604.4503 & 442.1283 & 272.5999 & 232.6874 \\
\hline Perdido & 217.8670 & 348.0072 & 284.9052 & 708.9631 & 533.1294 & 7209.4846 & 295.2022 & 217.0847 & 201.5665 \\
\hline Argonauta & 210.1954 & 235.1104 & 220.8853 & 548.9131 & 510.6751 & 7067.4240 & 280.8915 & 207.5135 & 148.4081 \\
\hline Marimba Field & 204.4973 & 201.8096 & 201.1820 & 499.6550 & 499.2126 & 6959.9421 & 270.8304 & 201.0535 & 141.9507 \\
\hline \begin{tabular}{|l|} 
Pazflor \\
\end{tabular} & 232.7337 & 271.4513 & 251.6582 & 625.8455 & 534.0504 & 7353.2505 & 310.9398 & 218.2910 & 148.9160 \\
\hline \multicolumn{10}{|c|}{ Initial Capital Investment (\$M) } \\
\hline Site & PWR & $\mathrm{FC1}$ & $\mathrm{FC2}$ & SV1 & SV2 & $\mathrm{SV} 3$ & PWR TEG & WELLL TEG & GRID \\
\hline Shtokman & 4916.3574 & 7449.4530 & 6291.4042 & 15728.5106 & 7169.7609 & 93464.2259 & 6446.7038 & 2928.5533 & 4042.6487 \\
\hline Chinook & 1669.6759 & 4148.0497 & 2974.1210 & 7435.3024 & 4179.0824 & 55121.4183 & 2297.3112 & 1681.6671 & 1183.9706 \\
\hline King & 1559.2664 & 1688.8266 & 1609.2890 & 4023.2225 & 3808.7512 & 53026.7047 & 2085.3088 & 1535.9989 & 1142.8013 \\
\hline Ormen Lange & 2435.8227 & 3817.1859 & 3159.2479 & 7898.1198 & 4833.7209 & 64701.7509 & 3308.9171 & 2033.8102 & 1733.6090 \\
\hline Perdido & 1622.1376 & 2600.9859 & 2126.3651 & 5315.9126 & 3993.3807 & 54209.5288 & 2203.8138 & 1616.2530 & 1499.5336 \\
\hline Argonauta & 1564.4353 & 1751.8334 & 1644.8392 & 4112.0981 & 3824.4907 & 53141.0212 & 2096.1756 & 1544.2637 & 1099.7027 \\
\hline Marimba Field & 1521.5770 & 1501.3618 & 1496.6415 & 3741.6037 & 3738.2758 & 52332.5971 & 2020.5010 & 1495.6746 & 1051.1340 \\
\hline Pazflor & 1733.9574 & 2025.1713 & 1876.2977 & 4690.7443 & 4000.3081 & 55290.8623 & 2322.1835 & 1625.3267 & 1103.5230 \\
\hline
\end{tabular}




\section{Figures}

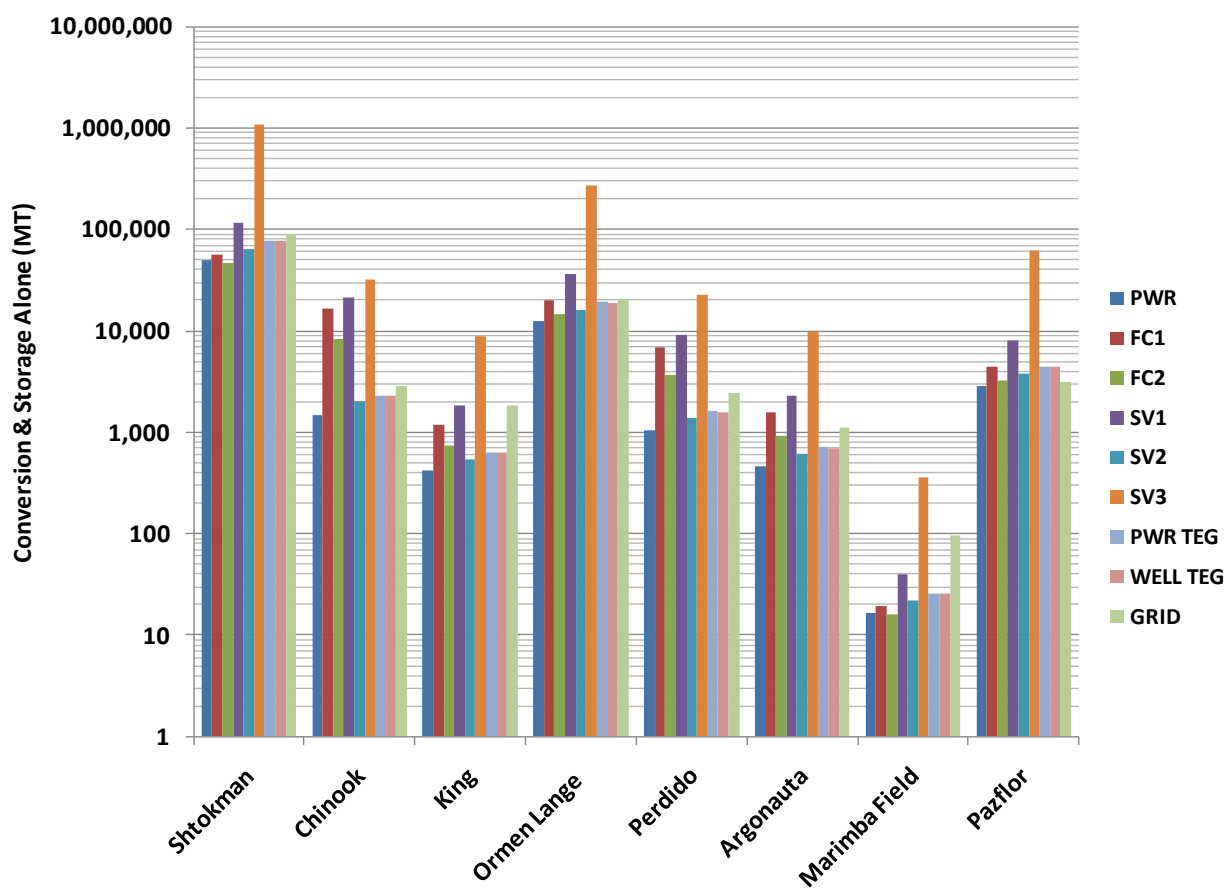

Figure 1 - Graphical comparison of the predicted masses of power generation and energy storage components, for each of the deep ocean hybrid systems, and for each of the con-ops cases

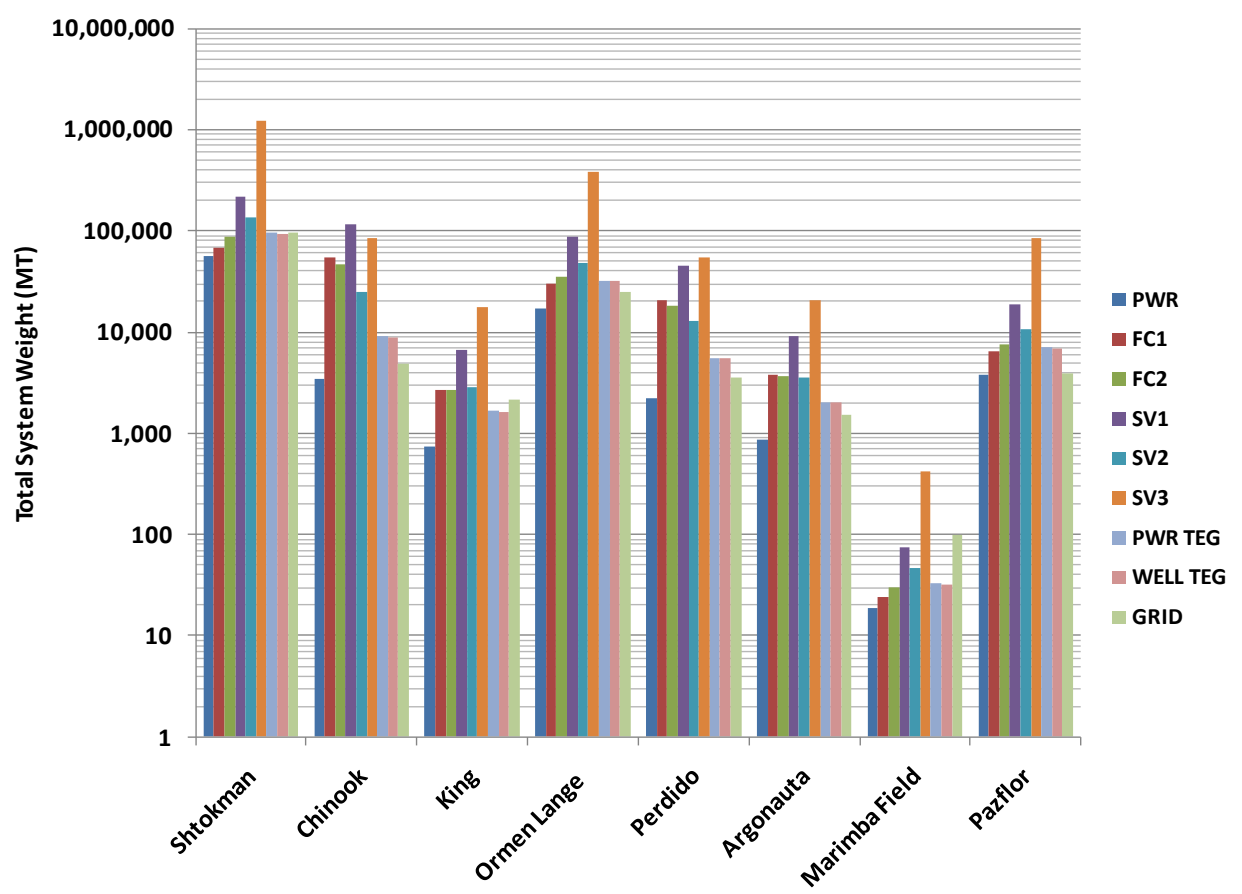

Figure 2-Graphical comparison of the predicted total masses of the deep ocean hybrid power generation and energy storage options, for each of the con-ops cases 


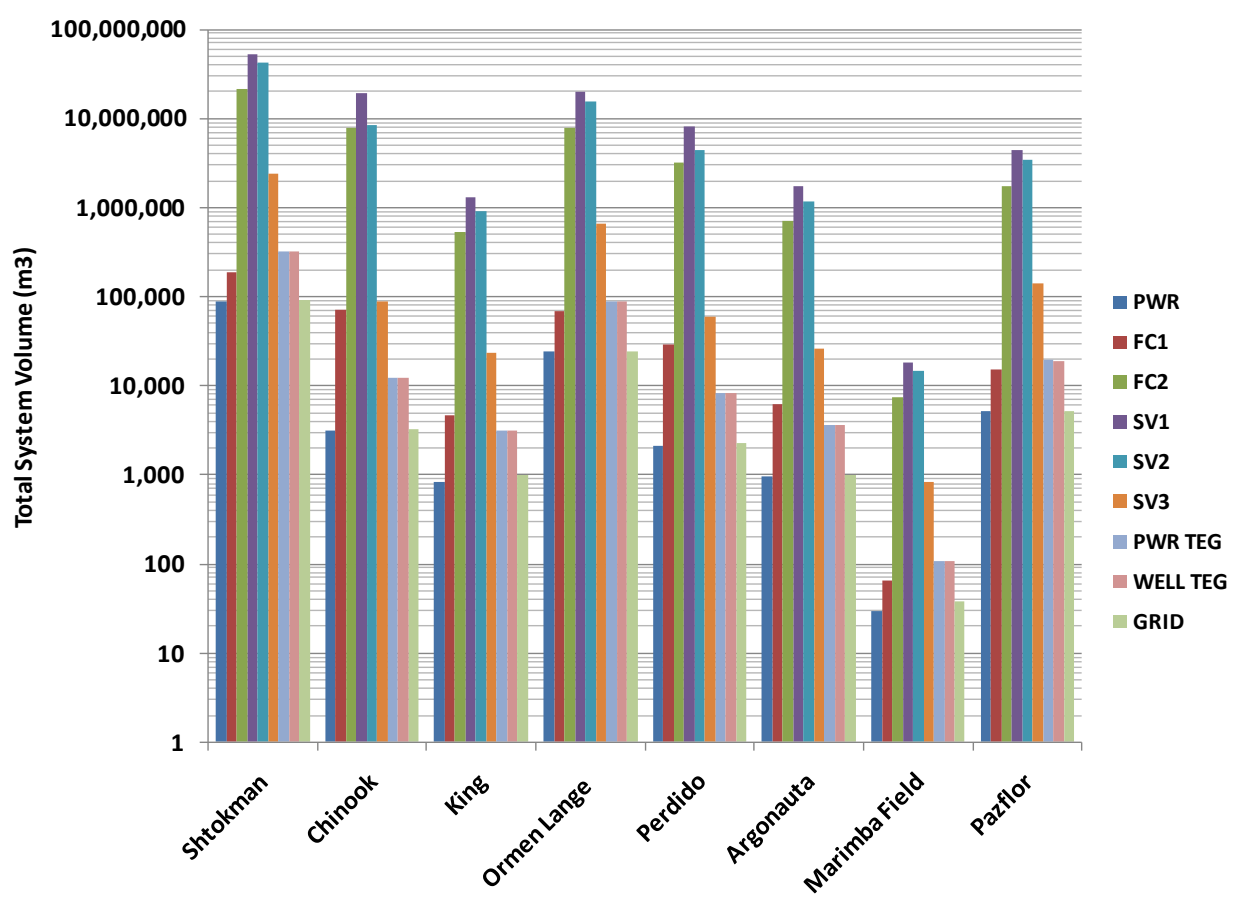

Figure 3-Graphical comparison of the predicted volumes of the deep ocean hybrid power generation and energy storage options, for each of the RPSEA con-ops cases

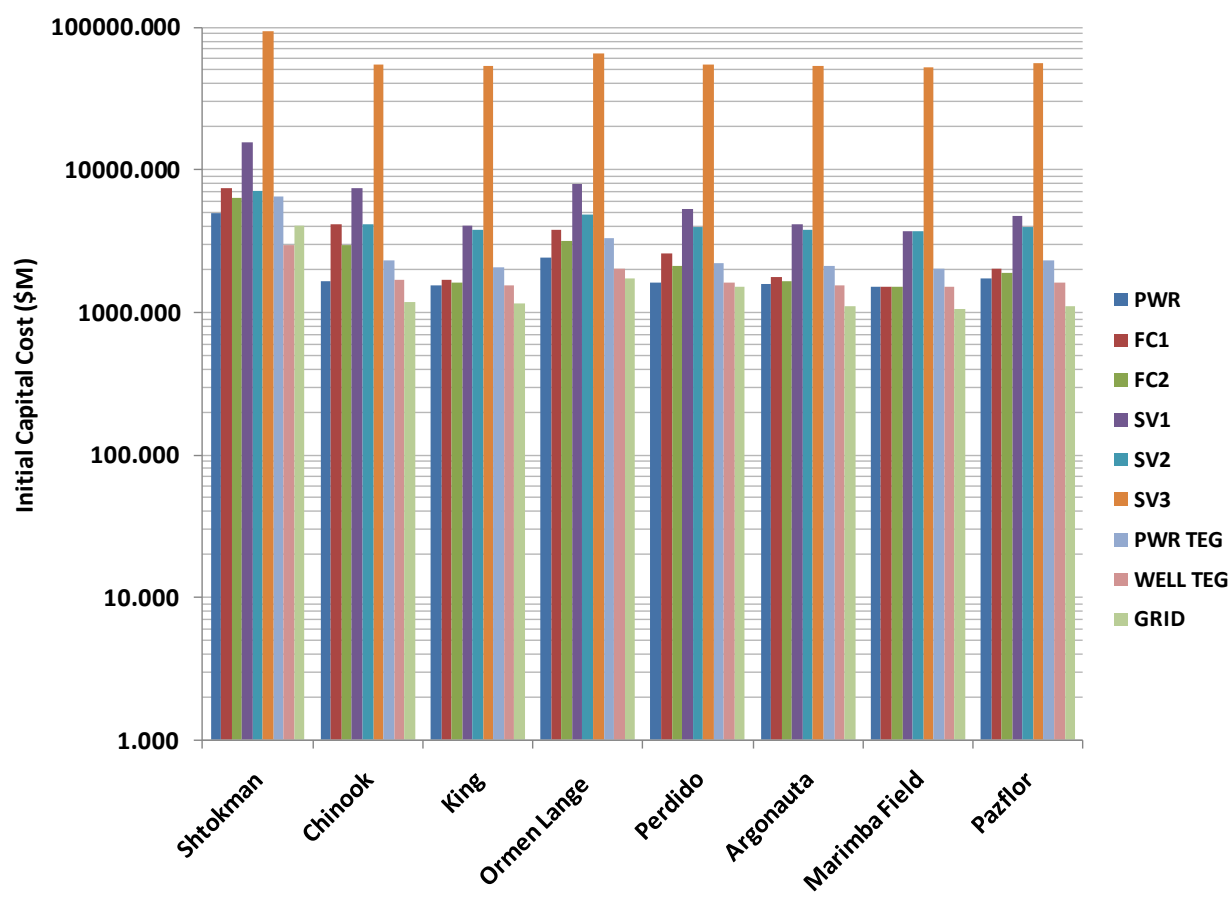

Figure 4-Graphical comparison of the predicted capital investment required for each deep ocean hybrid power generation and energy storage option, for each of the con-ops cases 


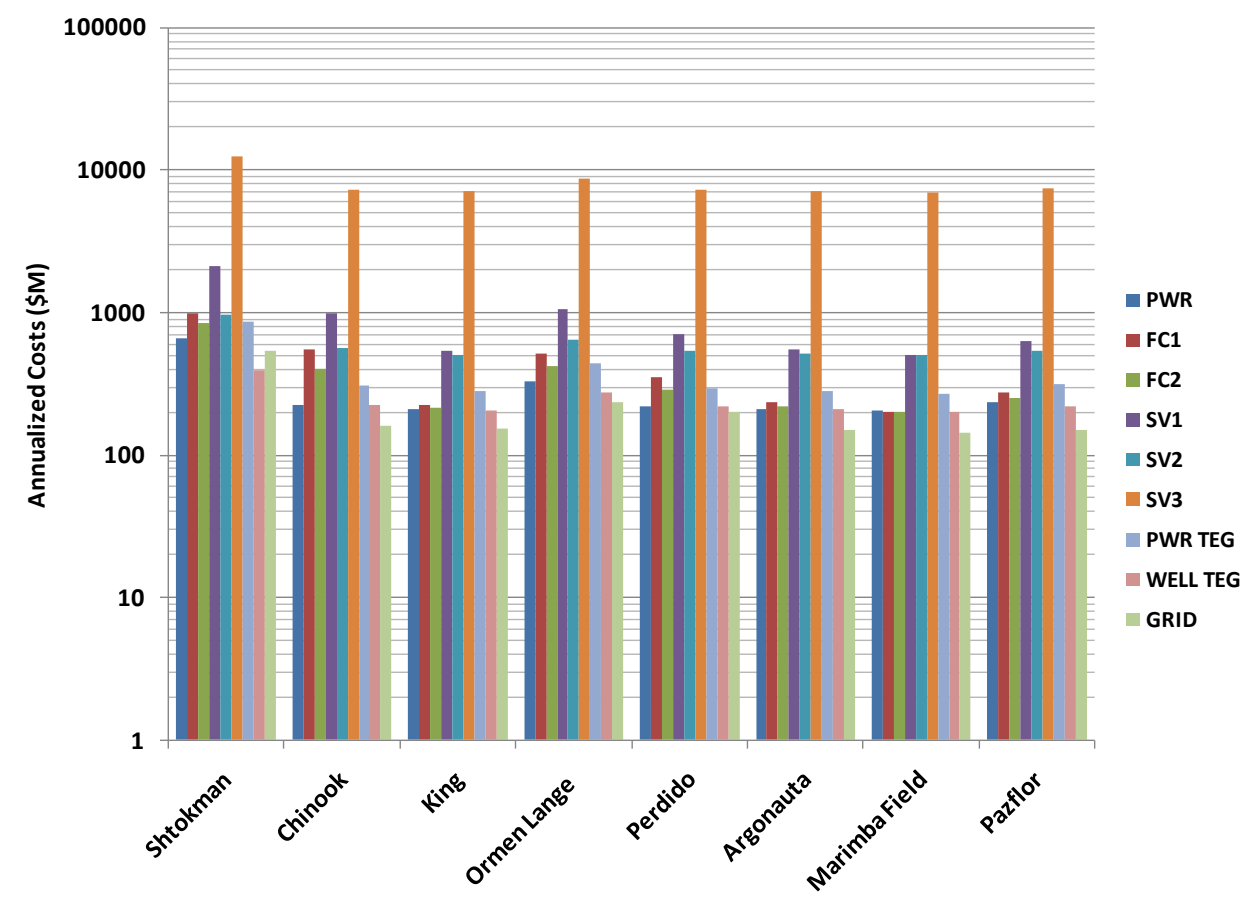

Figure 5-Graphical comparison of the predicted annualized costs for each deep ocean hybrid power generation and energy storage option, for each of the RPSEA con-ops cases

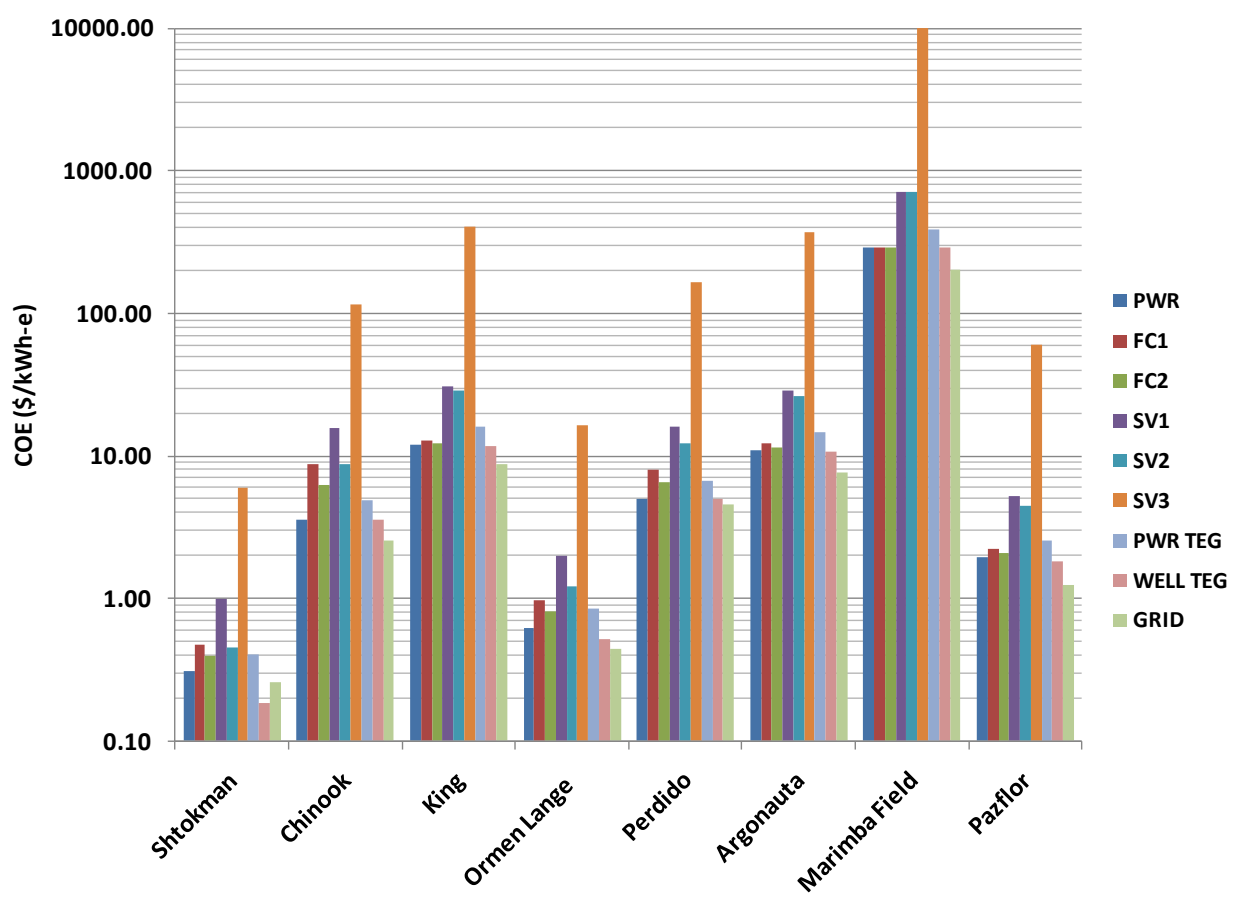

Figure 6-Graphical comparison of the predicted cost-of-electricity produced by each of the deep ocean hybrid power generation and energy storage systems, at each of the con-ops sites 


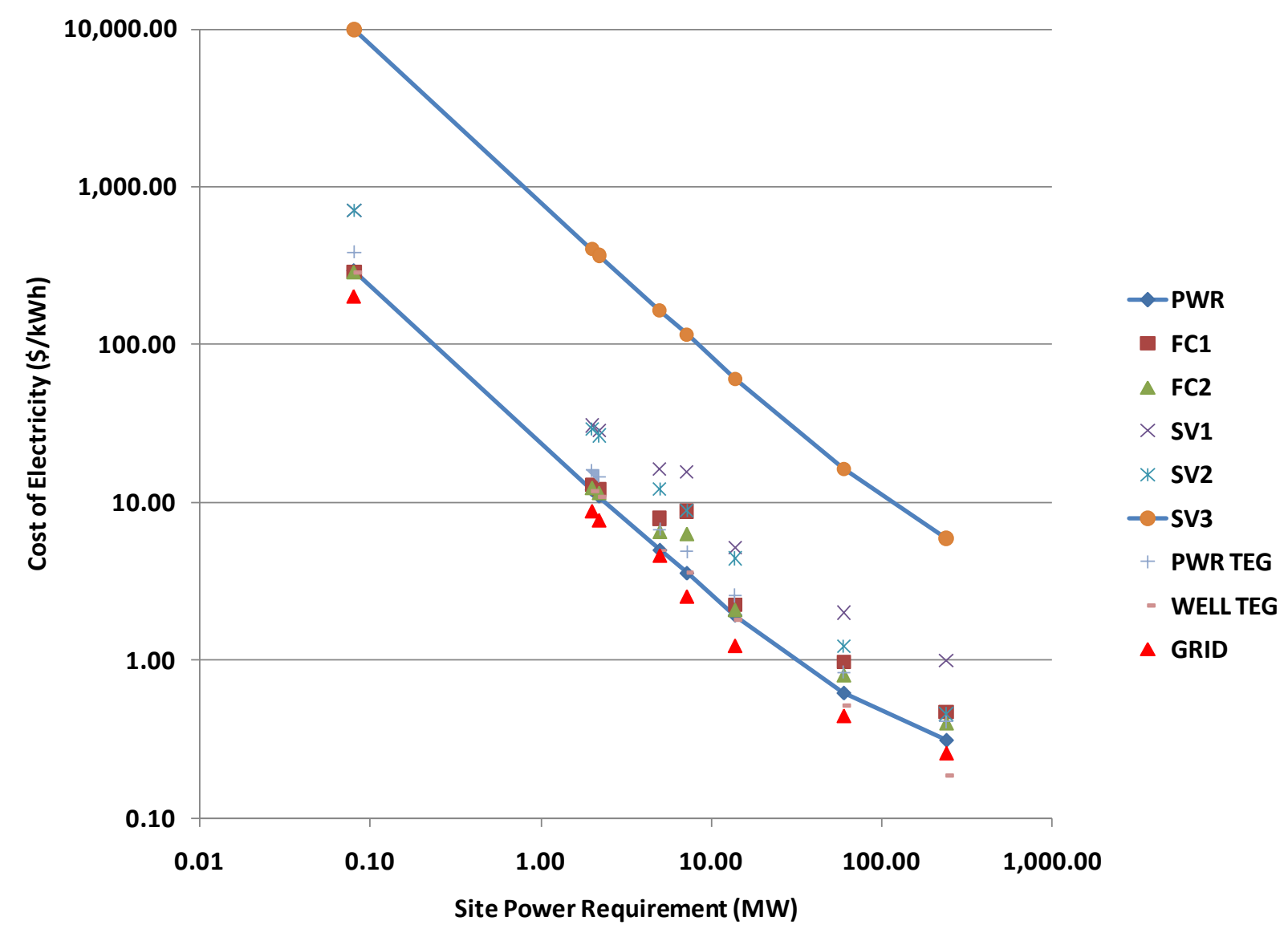

Figure 7 - The cost of electricity shows a very clear economy of scale, with the lowest electricity costs being realized for the largest sites 


\section{Appendix A - Background on World-Wide Use of Large and Modular Nuclear Reactors}

Table A 1 - The inventory of operating nuclear reactors world-wide, broken down into global regions including: West Europe; East Europe; America (North America); and Asia and Africa [Fukuda]

\begin{tabular}{|l|r|r|r|r|}
\hline & \multicolumn{4}{|c|}{ Worldwide Nuclear Reactors } \\
\hline & $\begin{array}{r}\text { Completed \& } \\
\text { Operating }\end{array}$ & $\begin{array}{r}\text { Completed \& } \\
\text { Operating }\end{array}$ & $\begin{array}{r}\text { Under } \\
\text { Construction }\end{array}$ & $\begin{array}{r}\text { Under } \\
\text { Construction }\end{array}$ \\
\hline Regions & Reactors & Total Capacity & Reactors & Total Capacity \\
\hline & Number & Gwe & Number & Gwe \\
\hline West Europe & 146 & 125.7 & 0.0 & 0.0 \\
\hline East Europe & 67 & 46.1 & 10.0 & 8.0 \\
\hline America & 124 & 112.4 & 1.0 & 0.7 \\
\hline Asia \& Africa & 104 & 74.5 & 22.0 & 18.4 \\
\hline World & 441 & 358.7 & 33.0 & 27.1 \\
\hline
\end{tabular}

Table A 2 - The inventory of spent nuclear fuel from nuclear reactor operations being stored worldwide, broken down into global regions including: West Europe; East Europe; America (North America); and Asia and Africa [Fukuda]

\begin{tabular}{|l|r|}
\hline \multicolumn{2}{|l|}{ Spent Nuclear Fuel Inventory } \\
\hline & SNF \\
\hline Regions & Total \\
\hline & t HM \\
\hline West Europe & 36,100 \\
\hline East Europe & 27,700 \\
\hline America & 83,300 \\
\hline Asia \& Africa & 23,900 \\
\hline World & 171,000 \\
\hline
\end{tabular}

Table A 3 - The world-wide inventory of relatively small modular nuclear reactors is shown with their corresponding country of origin and electrical generating capacity

\begin{tabular}{|l|l|l|}
\hline Reactor & Location & Power \\
\hline VK-300 & Atomenergoproekt, Russia & 300 MWe PWR \\
\hline CAREM & CNEA \& INVAP, Argentina & 27 MWe PWR \\
\hline KLT-40 & OKBM, Russia & 35 MWe PWR \\
\hline MRX & JAERI, Japan & $30-100$ MWe PWR \\
\hline IRIS-100 & Westinghouse-led, international & 100 MWe PWR \\
\hline B\&W mPower & Babcock \& Wilcox, USA & 125 MWe PWR \\
\hline SMART & KAERI, S. Korea & 100 MWe PWR \\
\hline NP-300 & Technicatome (Areva), France & $100-300$ MWe PWR \\
\hline HTR-PM & INET \& Huaneng, China & 105 MWe HTR \\
\hline PBMR & Eskom, South Africa, & 165 MWe HTR \\
\hline GT-MHR & General Atomics (USA), Minatom (Russia) et al & 280 MWe HTR \\
\hline BREST & RDIPE (Russia) & 300 MWe LMR \\
\hline FUJI & ITHMSO, Japan-Russia-USA & 100 MWe MSR \\
\hline
\end{tabular}



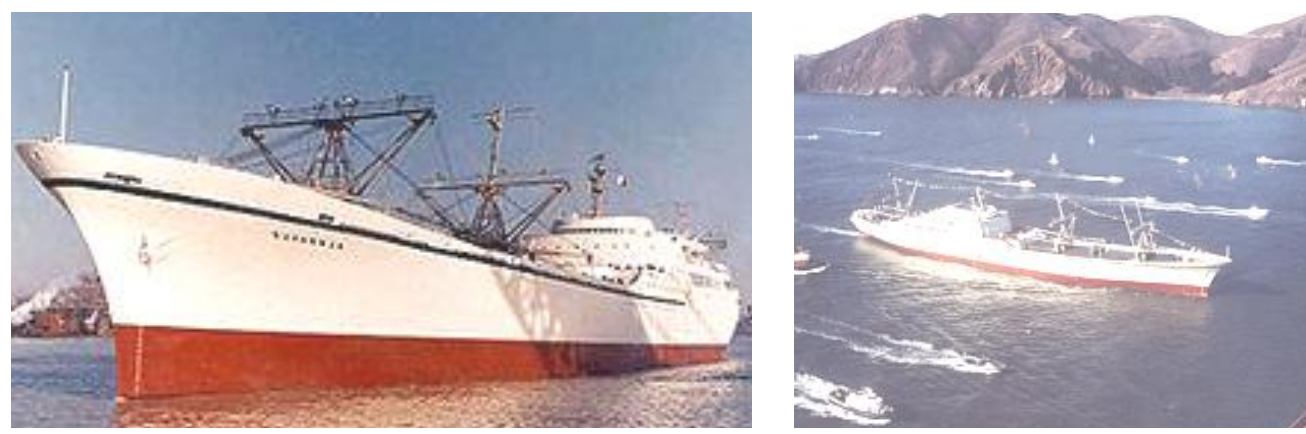

Figure A 1 - The commercial NS Savannah nuclear powered ship was built by New York Ship Building in Camden, New Jersey and had a 74 MW PWR built by Babcock \& Wilcox (B\&W) and sailed from 1970-79

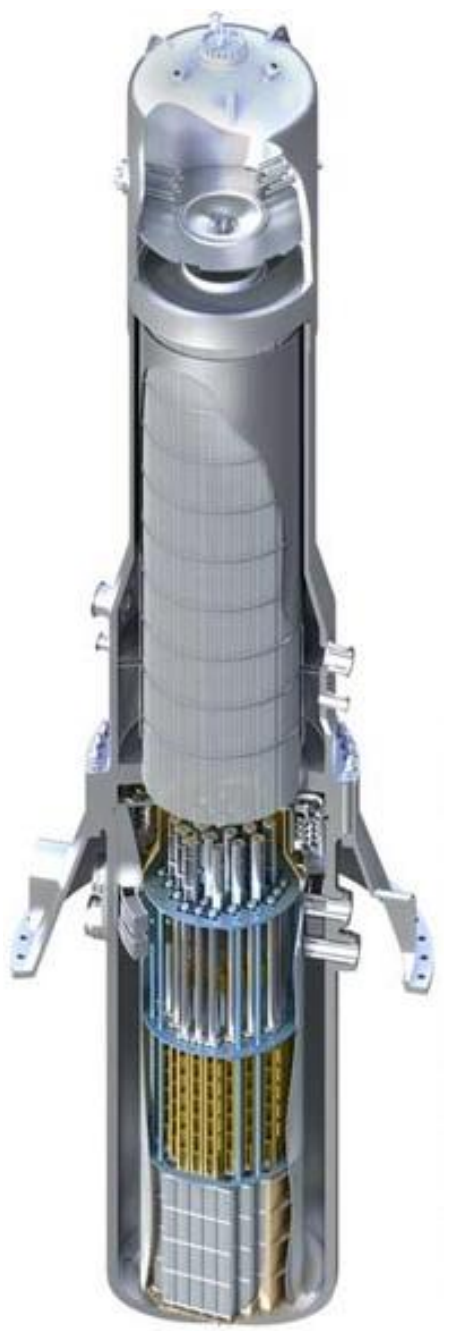

Figure A 2 - The B\&W mPower ${ }^{\mathrm{TM}}$ reactor, with its scalable, modular design, has the capacity to provide $125 \mathrm{MWe}$ to $750 \mathrm{MWe}$ or more for a five-year operating cycle without refueling, and is designed to produce clean, near-zero emission operations. This PWR is very similar in design to that used for the NS Savannah 


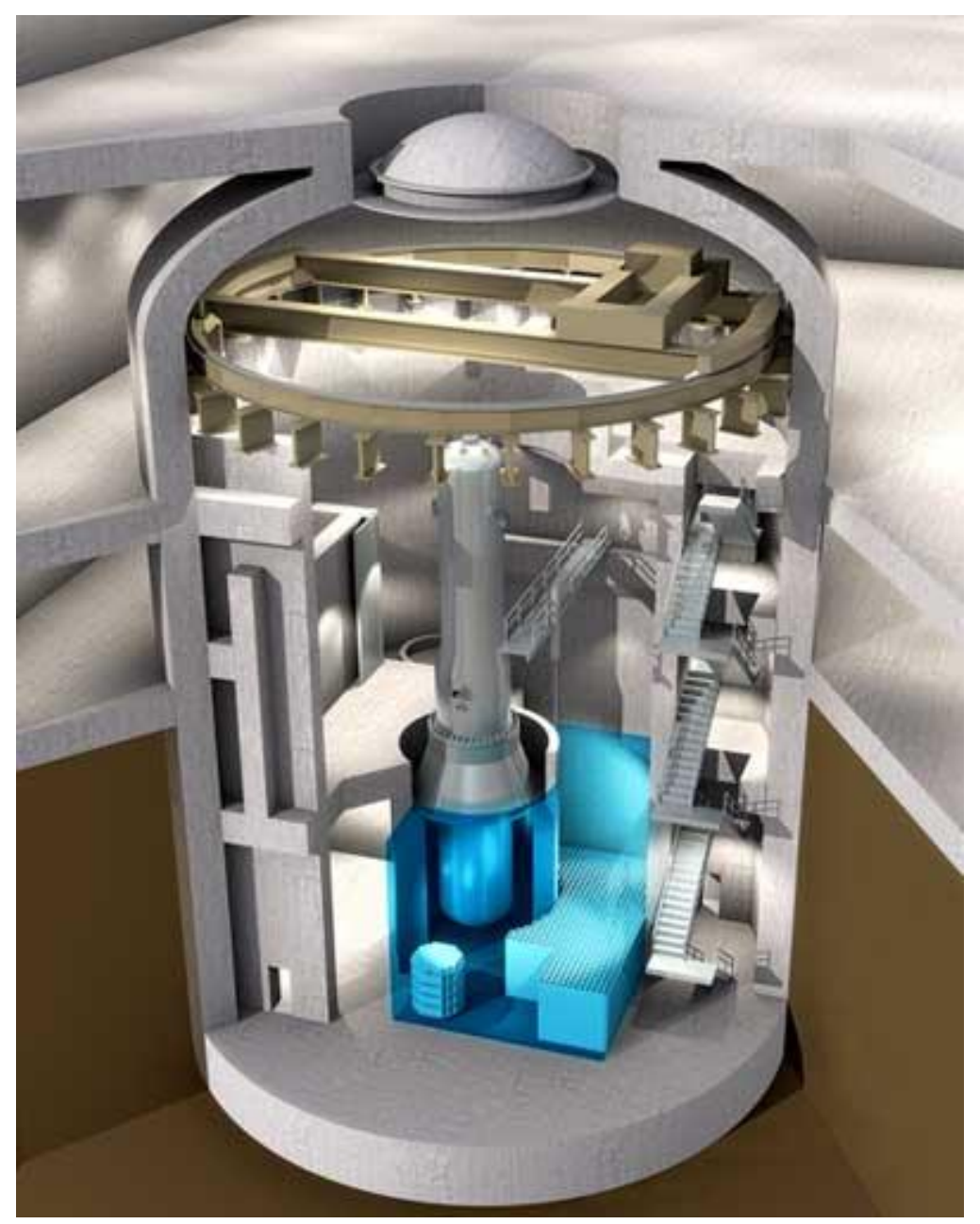

Figure A 3 - A single B\&W mPower ${ }^{\mathrm{TM}}$ module inside its own independent, underground containment

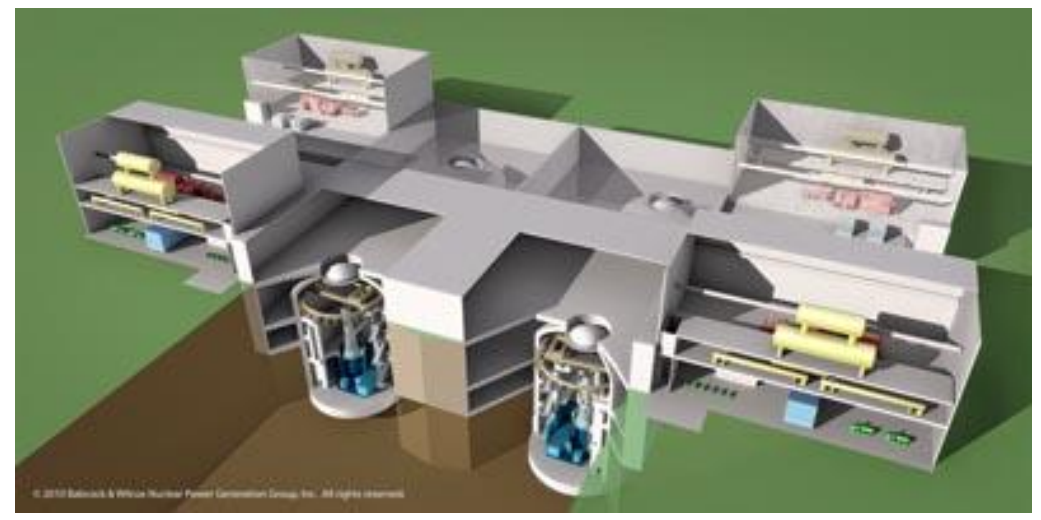

Figure A 4 - Four B\&W mPower ${ }^{\mathrm{TM}}$ nuclear reactors configured as a 500 megawatt nuclear power plant 


\section{Appendix B - Deep Ocean Experience with PEMFC Systems}
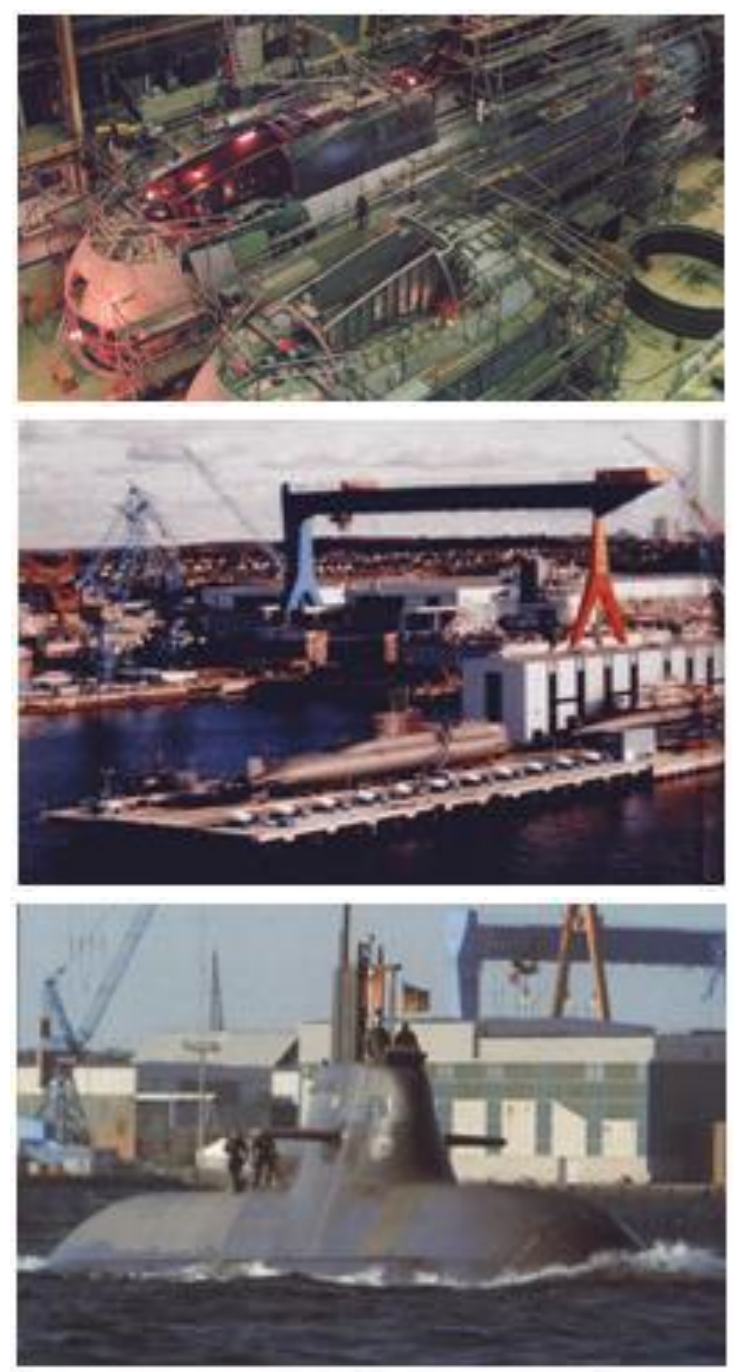

Figure B 1 - The left image shows the Class 212A fuel-cell powered submarine being constructed by HDW in Kiel, Germany. The center image shows the assembled submarine sitting in dry dock, and the right image shows the vessel after launch
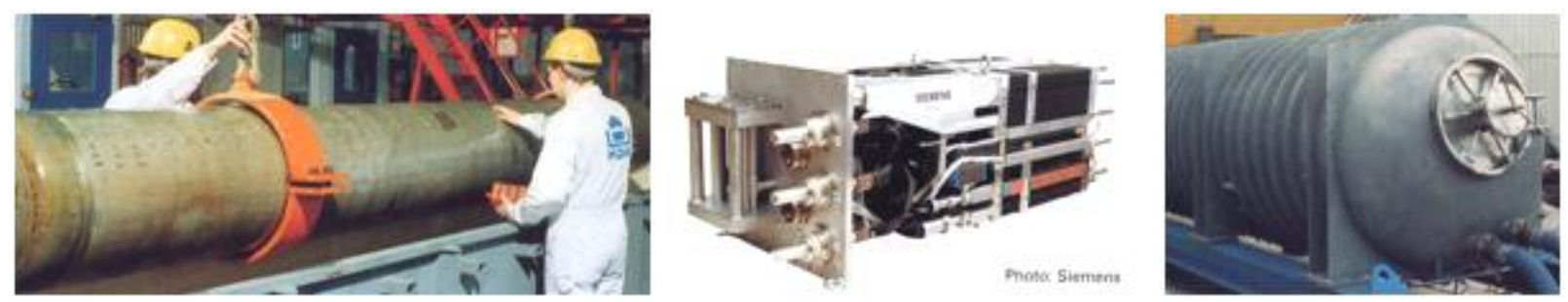

Figure B 2 - Components of the fuel cell system used by HDW shipyard in Kiel, Germany aboard sub-sea vessels 


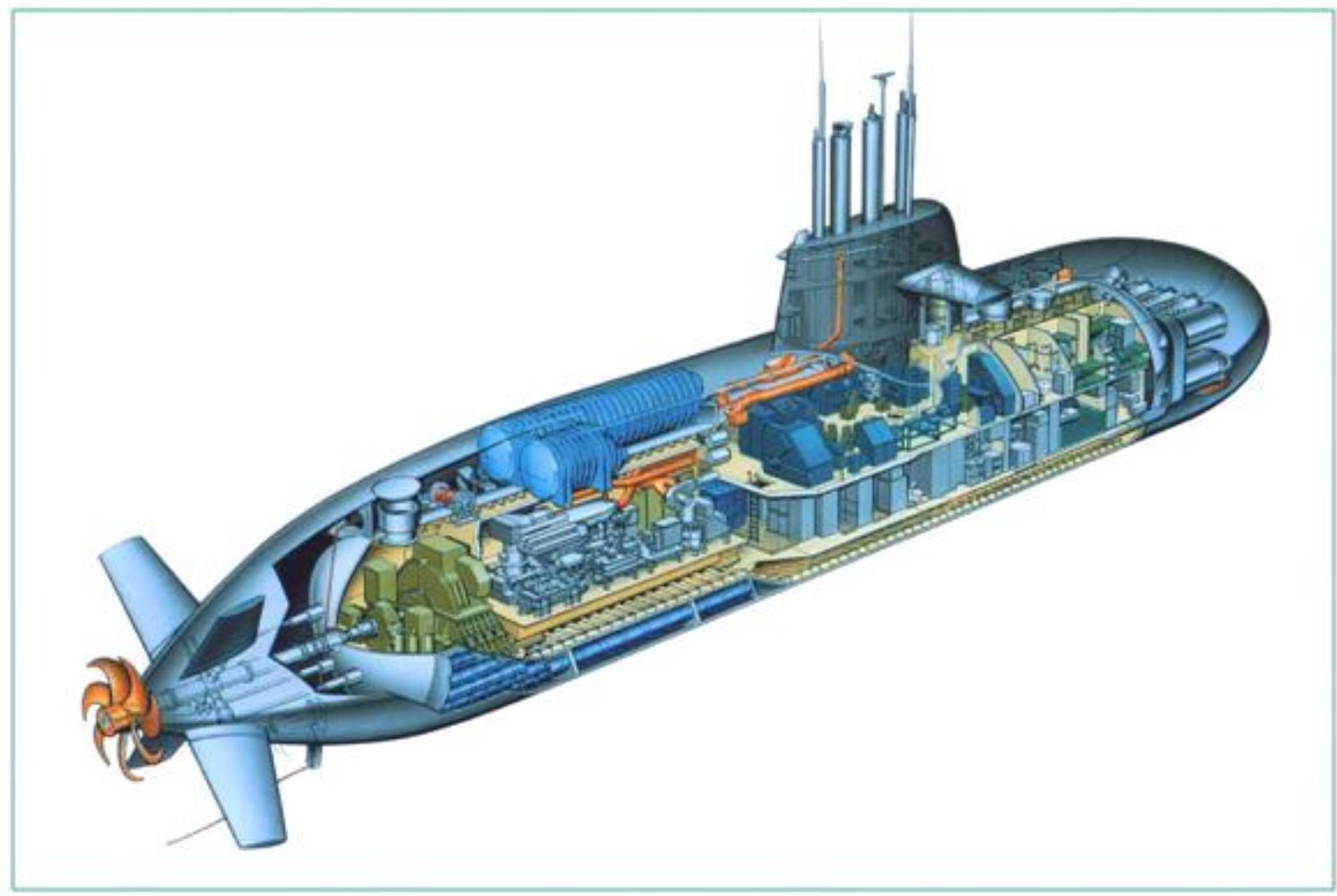

Figure B 3 - Three-dimensional schematic representation of the fuel-cell powered sub-sea vessel

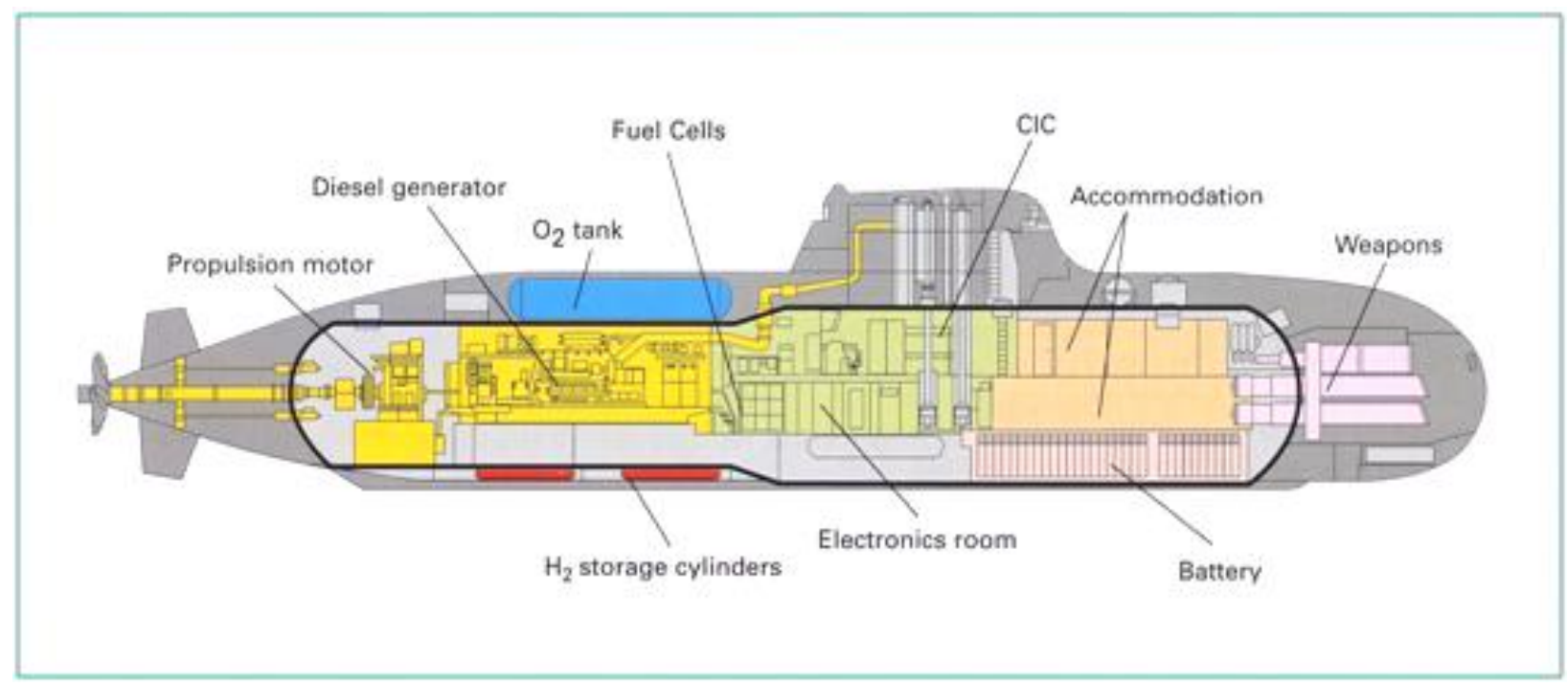

Figure B 4 - Two-dimensional schematic representation of the fuel-cell powered sub-sea vessel, showing the systems required for operation, including the oxygen storage tank, the fuel cells, and the hydrogen storage cylinders 


\section{Appendix C - Representative Composition and Properties for Oil and Gas from Well Head}

Table C 1 - Composition of typical oil and gas layer from typical deep-ocean well [Gonzalez SPE 110833]

\begin{tabular}{|l|c|c|c|c|c|c|c|c|}
\hline & \multicolumn{2}{|c|}{ Oil-Layer Fluid Composition (mole \%) } & \multicolumn{3}{|c|}{ Gas-Layer Fluid Composition (mole \%) } \\
\hline \multirow{2}{*}{ Component } & MW & $\begin{array}{c}\text { Flashed } \\
\text { Gas }\end{array}$ & $\begin{array}{c}\text { Flashed } \\
\text { Liquid }\end{array}$ & $\begin{array}{c}\text { Mono- } \\
\text { phasic } \\
\text { Fluid }\end{array}$ & MW & $\begin{array}{c}\text { Flashed } \\
\text { Gas }\end{array}$ & $\begin{array}{c}\text { Flashed } \\
\text { Liquid }\end{array}$ & $\begin{array}{c}\text { phasic } \\
\text { Fluid }\end{array}$ \\
\hline Carbon Dioxide & 44.01 & 0.07 & 0 & 0.05 & 44.01 & 0.05 & 0.00 & 0.05 \\
\hline Nitrogen & 28.01 & 0.18 & 0 & 0.12 & 28.01 & 0.00 & 0.00 & 0 \\
\hline Methane & 16.04 & 79.53 & 0 & 49.6 & 16.04 & 96.73 & 0.00 & 92.62 \\
\hline Ethane & 30.07 & 7.40 & 0 & 4.61 & 30.07 & 0.96 & 0.00 & 0.92 \\
\hline Propane & 44.10 & 6.49 & 0.56 & 4.26 & 44.10 & 0.90 & 0.09 & 0.87 \\
\hline Butane & 58.12 & 3.93 & 1.35 & 2.95 & 58.12 & 0.65 & 0.38 & 0.65 \\
\hline Pentane & 72.15 & 1.98 & 2.67 & 2.24 & 72.15 & 0.47 & 1.27 & 0.5 \\
\hline C6 & 86.20 & 0.26 & 3.79 & 1.59 & 86.20 & 0.11 & 2.57 & 0.22 \\
\hline C-Pentane & 84.16 & 0.00 & 0.69 & 0.26 & 84.16 & 0.00 & 0.69 & 0.03 \\
\hline Benzene & 78.11 & 0.00 & 0.12 & 0.05 & 78.11 & 0.00 & 0.05 & 0.00 \\
\hline Cyclohexane & 84.16 & 0.07 & 0.46 & 0.22 & 84.16 & 0.04 & 0.40 & 0.05 \\
\hline C7 & 100.20 & 0.04 & 4.22 & 1.61 & 100.20 & 0.04 & 5.80 & 0.28 \\
\hline C-Hexane & 98.19 & 0.03 & 1 & 0.39 & 98.19 & 0.02 & 1.25 & 0.07 \\
\hline Toluene & 92.14 & 0.00 & 0.64 & 0.24 & 92.14 & 0.00 & 0.88 & 0.04 \\
\hline C8 & 107.00 & 0.01 & 4.97 & 1.87 & 107.00 & 0.01 & 8.65 & 0.37 \\
\hline E-Benzene & 106.17 & 0.00 & 0.37 & 0.14 & 106.17 & 0.00 & 0.65 & 0.03 \\
\hline Xylene & 106.17 & 0.00 & 1.02 & 0.39 & 106.17 & 0.00 & 1.26 & 0.06 \\
\hline C9 & 121.00 & 0.01 & 4.25 & 1.6 & 121.00 & 0.01 & 8.09 & 0.35 \\
\hline C10 & 134.00 & 0.00 & 5.33 & 2.01 & 134.00 & 0.00 & 9.16 & 0.39 \\
\hline C11 & 147.00 & 0.00 & 7.6 & 2.86 & 147.00 & 0.00 & 8.79 & 0.37 \\
\hline C12+ & 291.40 & 0.00 & 60.99 & 19.82 & 162.65 & 0.00 & 50.00 & 2.12 \\
\hline MW & & 22.02 & 221.04 & 96.91 & & 17.15 & 177.24 & 23.95 \\
\hline Mole Ratio & & 0.6237 & 0.3763 & & & 0.9376 & 0.0424 & \\
\hline
\end{tabular}


Table C 2 - Physical properties of oil and gas layers from typical deep-ocean (sub-surface) well

\begin{tabular}{|c|c|c|}
\hline & $\begin{array}{l}\text { Oil-Lower } \\
\text { Layer }\end{array}$ & $\begin{array}{c}\text { Gas-Upper } \\
\text { Layer }\end{array}$ \\
\hline \multicolumn{3}{|l|}{ Reservoir Conditions } \\
\hline Pressure (psia) & 16,990 & 15,740 \\
\hline Temperature (F) & 184 & 170 \\
\hline Depth (ft MD) & 22,700 & 21,900 \\
\hline \multicolumn{3}{|l|}{ Reservoir Fluid Properties } \\
\hline Oil-Base Mud OBM Contamination (wt. \% RF Basis) & 20 & 3.1 \\
\hline Gas-Oil Ratio GOR - Single-Stage Flash (scf/bbl) ... original & 852 & 13,693 \\
\hline Gas-Oil Ratio GOR - Single-Stage Flash (scf/b bl) ... decontaminated & 1,133 & 15,253 \\
\hline Bubble Point Prtessure at Reservoir Temperature (psia) & 3,427 & \\
\hline Bubble Point at $100^{\circ} \mathrm{F}$ (psia) & 2,940 & \\
\hline Dew Point Pressure at Reservoir Temperature (psia) & & 10,562 \\
\hline \multicolumn{3}{|l|}{ Properties at Reservoir Conditions } \\
\hline Compressibility (1E-6/psi) & 4.40 & 2.10 \\
\hline Density (g/cc) & 0.75 & 0.42 \\
\hline \multicolumn{3}{|l|}{ Properties at Saturation Conditions } \\
\hline Compressibility (1E-6/psi) & 12.70 & 1.60 \\
\hline Density (g/cc) & 0.67 & 0.38 \\
\hline FVF - Single-Stage Flash at Reservoir Temp. \& Press. & $1,322.00$ & \\
\hline \multicolumn{3}{|l|}{ Properties at $60^{\circ} \mathrm{F}$} \\
\hline Molar Mass & 220.42 & 176.06 \\
\hline Molar Mass & 229.59 & 177.24 \\
\hline Oil-Base Mud OBM Contamination (wt. \% STO Basis) & 23.30 & 9.80 \\
\hline API - Single-Stage STO ... Original & 36.10 & 43.50 \\
\hline API - Single-Stage STO ... De-Contaminated & 32.80 & 42.50 \\
\hline Density (g/cc) ... Original & 0.84 & 0.81 \\
\hline Density $(g / c c)$... De-Contaminated & 0.86 & 0.81 \\
\hline Gas Gravity & 0.76 & 0.59 \\
\hline
\end{tabular}


Table C 3 - Pressure as a function of time at various points in typical deep-ocean well system

\begin{tabular}{|r|c|c|c|c|c|c|c|}
\hline & Oil Layer & BHFP & $\begin{array}{c}\text { Oil- } \\
\text { Lower } \\
\text { Layer }\end{array}$ & $\begin{array}{c}\text { Gas- } \\
\text { Upper } \\
\text { Layer }\end{array}$ & $\begin{array}{c}\text { Comingle } \\
\text { Point }\end{array}$ & $\begin{array}{c}\text { Well } \\
\text { Head }\end{array}$ & Separator \\
\hline years & psi & psi & psi & psi & psi & psi & psi \\
\hline 0 & 17000 & 16700 & 16990 & 15,740 & 8,000 & 2,100 & 1,200 \\
\hline 1 & 15600 & 15260 & 15590 & 14,300 & 8,200 & 2,120 & 1,200 \\
\hline 2 & 14200 & 13820 & 14190 & 12,860 & 8,400 & 2,140 & 1,200 \\
\hline 3 & 12800 & 12380 & 12790 & 11,420 & 8,600 & 2,160 & 1,200 \\
\hline 4 & 11400 & 10940 & 11390 & 9,980 & 8,800 & 2,180 & 1,200 \\
\hline 5 & 10000 & 9500 & 9990 & 8,540 & 9,000 & 2,200 & 1,200 \\
\hline
\end{tabular}

Table C 4 - Temperature as a function of time at various points in typical deep-ocean well system

\begin{tabular}{|r|c|c|c|c|c|c|c|}
\hline & Oil Layer & BHFP & $\begin{array}{c}\text { Oil- } \\
\text { Lower } \\
\text { Layer }\end{array}$ & $\begin{array}{c}\text { Gas- } \\
\text { Upper } \\
\text { Layer }\end{array}$ & $\begin{array}{c}\text { Comingle } \\
\text { Point }\end{array}$ & $\begin{array}{c}\text { Well } \\
\text { Head }\end{array}$ & Separator \\
\hline years & ${ }^{\circ} \mathrm{F}$ & ${ }^{\circ} \mathrm{F}$ & ${ }^{\circ} \mathrm{F}$ & ${ }^{\circ} \mathrm{F}$ & ${ }^{\circ} \mathrm{F}$ & ${ }^{\circ} \mathrm{F}$ & ${ }^{\circ} \mathrm{F}$ \\
\hline 0 & 180 & 180 & 184 & 170 & 145 & 115 & 100 \\
\hline 1 & 180 & 180 & 184 & 170 & 144 & 120 & 105 \\
\hline 2 & 180 & 180 & 184 & 170 & 143 & 125 & 110 \\
\hline 3 & 180 & 180 & 184 & 170 & 142 & 125 & 110 \\
\hline 4 & 180 & 180 & 184 & 170 & 141 & 125 & 110 \\
\hline 5 & 180 & 180 & 184 & 170 & 140 & 125 & 110 \\
\hline
\end{tabular}

Table C 5 - Gas-to-oil ratios (GORs) for deep-ocean wells at various times

\begin{tabular}{|c|c|}
\hline Time & GOR \\
\hline years & $\mathrm{scf} / \mathrm{bbl}$ \\
\hline 0 & 900 \\
\hline 1 & 1,120 \\
\hline 2 & 1,340 \\
\hline 3 & 1,560 \\
\hline 4 & 1,780 \\
\hline 5 & 2,000 \\
\hline
\end{tabular}




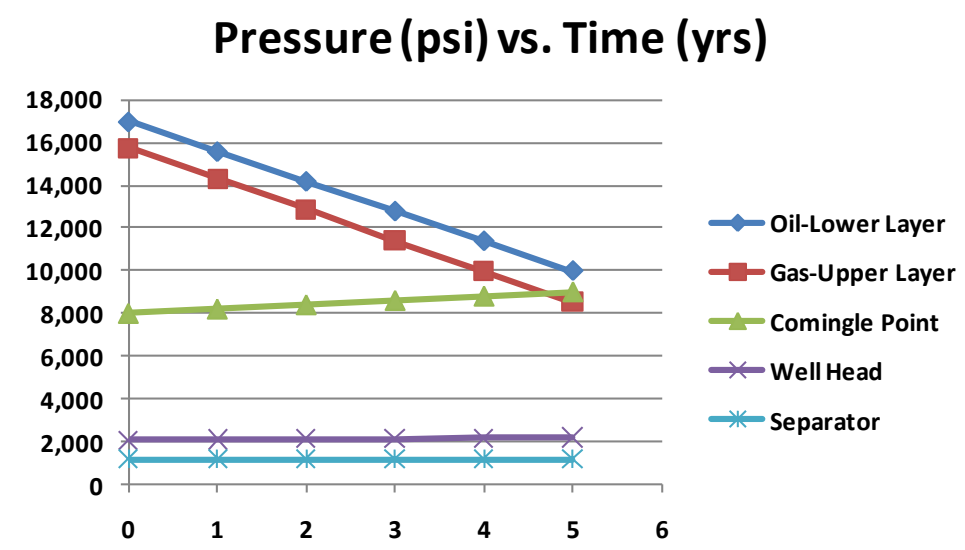

Figure C 1 - Pressure as a function of time at various points in typical deep-ocean well system

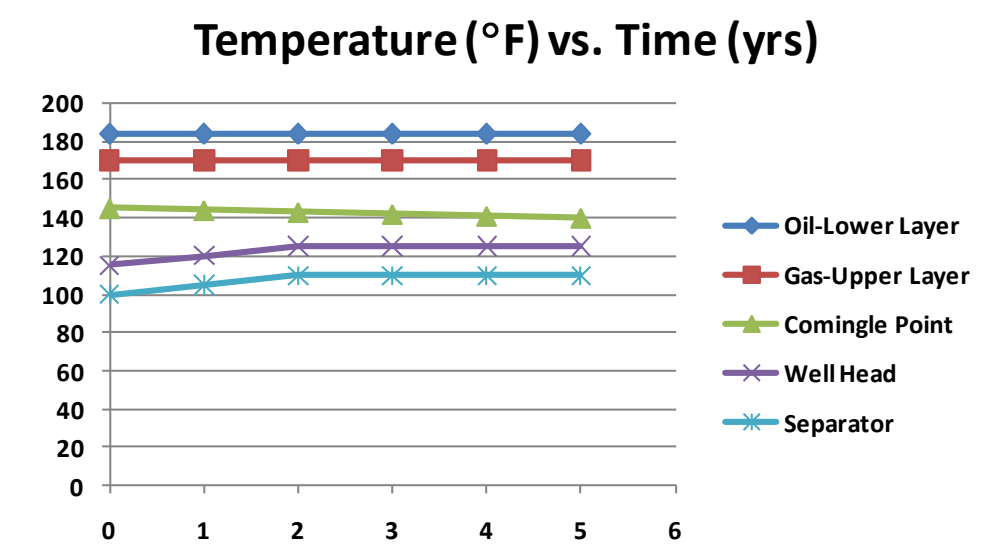

Figure C 2 - Temperature as a function of time at various points in typical deep-ocean well system

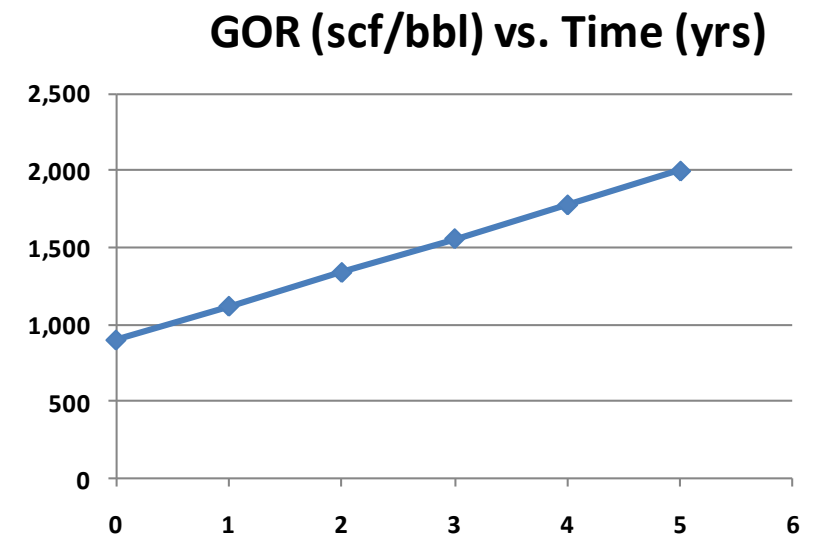

Figure C 3 - Gas-to-oil ratio (GOR) for production from typical deep-ocean well system 


\section{Appendix D - Classes of Thermoelectric Materials and Devices}

Table D 1 - Summary of practical thermoelectric materials, categorized as tellurides, silicon-germanium alloys, silicides, sulfides, antimonides and superlattices, with their corresponding operating temperature and dimensionless figure of merit, used to estimate the overall device efficiency

\begin{tabular}{|c|c|c|c|c|c|}
\hline Family & Type & Compound & $\mathrm{T}(\mathrm{K})$ & $\overline{Z 1}$ & Source \\
\hline \multirow{7}{*}{ Tellurides } & p & $25 \%$ Bi2Te3 + 75\% Sb2Te3 & 300 & 0.98 & Rosi, 1968 \\
\hline & n & $75 \%$ Bi2Te3 + 25\% Bi2Se3 & 300 & 0.72 & Rosi, 1968 \\
\hline & $p$ & $\mathrm{PbTe}$ & 600 & 1.05 & Rosi, 1968 \\
\hline & n & PbTe & 600 & 1.05 & Rosi, 1968 \\
\hline & $\mathbf{n}$ & $\mathrm{Pb} 0.75 \mathrm{Sn} 0.25 \mathrm{Te}$ & 900 & 1.44 & Wood, 1988 \\
\hline & p & $(\mathrm{GeTe}) 0.95(\mathrm{Bi} 2 \mathrm{Te} 3)$ & 750 & 1.28 & Wood, 1988 \\
\hline & $p$ & AgSbTe2 & 650 & 1.17 & Wood, 1988 \\
\hline \multirow{2}{*}{ Si-Ge Alloys } & p & Si70Ge30 & 1000 & 1.00 & Rosi, 1968 \\
\hline & n & Si70Ge30 & 1000 & 1.10 & Rosi, 1968 \\
\hline \multirow{3}{*}{\begin{tabular}{|l} 
Sillicides \\
\end{tabular}} & $\mathbf{n}$ & $\mathrm{FeSi} 2+3 \% \mathrm{Co}$ & 1000 & 008 & Matsubari 1992 \\
\hline & p & Ru2Si3 & 700 & \begin{tabular}{|l|}
0.00 \\
0.00
\end{tabular} & Ohta, 1992 \\
\hline & n & Ru2Si3 & 500 & 0.01 & Ohta, 1992 \\
\hline \multirow[t]{4}{*}{ Sulfides } & p & Ce3-xS4 $(0.00<x<0.33)$ & 1000 & 0.43 & Cutler, 1964 \\
\hline & $p$ & Ce 3-x S4 $(0.30<x<0.33)$ & 1000 & 1.03 & Cutler, 1964 \\
\hline & n & LaS1.445 & 1000 & 1.53 & Kamarzin, 1981 \\
\hline & $p$ & US & 573 & 0.06 & Gmelin \\
\hline Antimonides & $p$ & IrSb3 & 773 & 0.50 & Caillat, 1992 \\
\hline & & & & & \\
\hline Superatice & & $\mathrm{PbTe} / \mathrm{Te}$ & 300 & 1.90 & Harman, 1998 \\
\hline
\end{tabular}

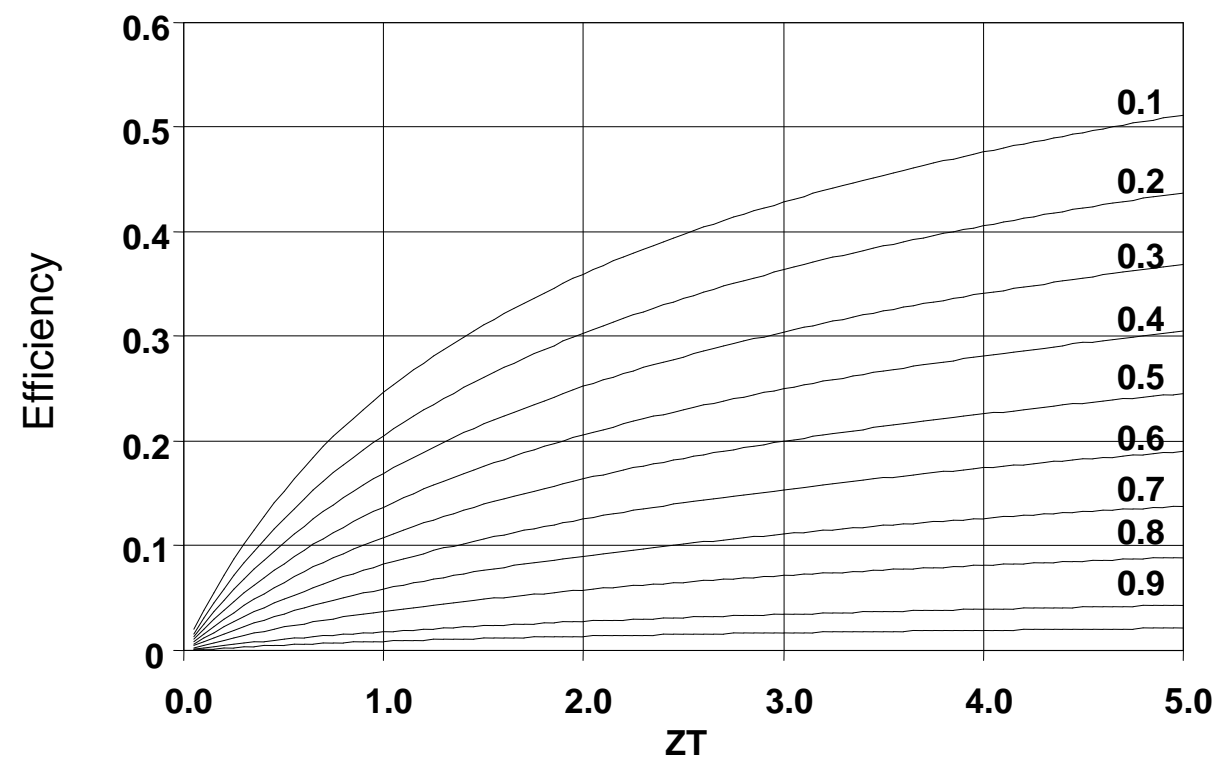

Figure D 1 - Efficiency $(\eta)$ as a function of $Z T$ for $T_{d} / T_{h}$ ratios from 0.1 to 0.9 


\section{Appendix E-Deep Ocean Currents}

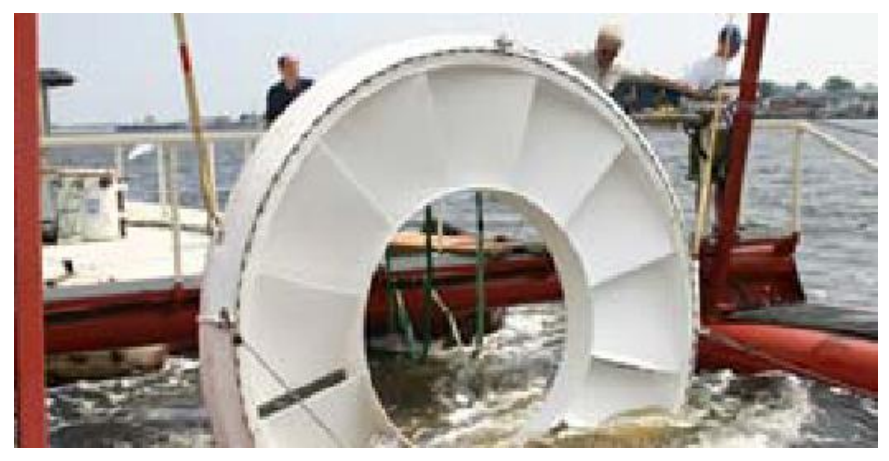

Figure E 1 - Advanced turbine for the conversion of deep ocean current to shaft energy 


\section{Appendix F - Energy Storage Technologies}

Table F 1 - A comparison of energy storage technologies considered for RPSEA hybrid system

\begin{tabular}{|c|c|c|c|c|c|c|c|}
\hline Parameter & Units & $\mathrm{Pb}$ Acid & AgZn & Nas & ZEBRA & Li-lon & $\begin{array}{c}\text { Regenerative } \\
\text { Fuel Cell } \\
\end{array}$ \\
\hline Anode & none & & $\mathrm{Zn}$ & $\mathrm{Na}$ & $\mathrm{Na}$ & LiC6 & $\mathrm{PtRu} / \mathrm{C}$ \\
\hline Cathode & none & $\mathrm{PbO}_{2}$ & $\mathrm{AgO} / \mathrm{Ag}_{2} \mathrm{O}$ & $\mathrm{S}$ & $\mathrm{NiCl}_{2}$ & $\mathrm{Li}_{\mathrm{x}}(\mathrm{Ni}, \mathrm{Co}) \mathrm{O}_{2}$ & $\mathrm{Pt} / \mathrm{C}$ \\
\hline Separator & none & Polyethylene & Cellophane & $\beta^{\prime \prime}-\mathrm{Al}_{2} \mathrm{O}_{3}$ & $\beta^{\prime \prime}-\mathrm{Al}_{2} \mathrm{O}_{3}$ & Polyethylene & Nafion \\
\hline Electrolyte Salt & none & $\mathrm{H}_{2} \mathrm{SO}_{4}$ & $40 \% \mathrm{KOH}$ & None & $\mathrm{NaAICl}_{4}$ & $1 \mathrm{M} \mathrm{LiPF} 6$ & None \\
\hline Electrolyte Solvent & none & $\mathrm{H}_{2} \mathrm{O}$ & $\mathrm{H}_{2} \mathrm{O}$ & None & None & EC:DMC:DEC & $\mathrm{H}_{2} \mathrm{O}$ \\
\hline Toxic Materials Required & elements & $\mathrm{Pb}, \mathrm{Sb}$ & None & $S$ & $\mathrm{Ni}$ & $\mathrm{Ni}, \mathrm{Co}, \mathrm{LiPF}_{6}$ & None \\
\hline Strategic Materials Required & elements & None & $\mathrm{Ag}$ & None & $\mathrm{Ni}$ & $\mathrm{Ni}, \mathrm{Co}, \mathrm{LiPF}_{6}$ & $\mathrm{Pt}, \mathrm{Ru}$ \\
\hline Minimum Operating Temperature & degrees C & -40 & -20 & 290 & 220 & -30 & 30 \\
\hline Nominal Operating Temperature & degrees C & 30 & 30 & $310-350$ & $270-350$ & 30 & 90 \\
\hline Maximum Operting Temperature & degrees C & 60 & 60 & 390 & 450 & 60 & 120 \\
\hline Minimum Operating Voltage & v & 1.75 & 1.30 & 1.78 & 1.72 & 3.00 & 0.50 \\
\hline Nominal Operating Voltage & $\mathrm{V}$ & 1.90 & 1.50 & 1.90 & 2.25 & 3.80 & 0.70 \\
\hline Maximum Operating Voltage & $\mathrm{V}$ & 2.00 & 1.70 & 1.95 & 2.67 & 4.00 & 1.20 \\
\hline Open Circuit Voltage & $\mathrm{V}$ & 2.10 & 1.86 & 2.08 & 2.58 & 4.10 & 1.20 \\
\hline Cell Impedance & milliohms & NA & 5 to 15 & 5 to 32 & 10 to 45 & 5 to 10 & NA \\
\hline Peak Specific Power & W/kg & 210 & 5560 & $215-360$ & $250-390$ & 1,100 & NA \\
\hline Specific Power & W/kg & 20 & $5560-1470$ & $390-250$ & $171-169$ & $1100-74$ & 27 \\
\hline Power Density & W/L & 51 & $9530-2520$ & $604-386$ & $265-261$ & $2270-147$ & 17 \\
\hline Specific Energy & Wh/kg & $20-35$ & $105-110$ & $117-226$ & $94-119$ & $75-182$ & 326 \\
\hline Energy Density & Wh/L & $50-90$ & $180-300$ & $147-370$ & $148-183$ & $139-359$ & 209 \\
\hline Coulombic Efficiency (Ah/Ah) & $\%$ & $80-90 \%$ & $90 \%$ & $89-92 \%$ & $\sim 100 \%$ & $99 \%$ & $90 \%$ \\
\hline Electrical Efficiency (Wh/Wh) & $\%$ & $70-75 \%$ & $75 \%$ & NA & NA & $95 \%$ & $43 \%$ \\
\hline Self Discharge Rate & $\%$ per mo. & $<3$ & $<3$ & $<1$ & $<1$ & $<2$ & NA \\
\hline \begin{tabular}{|l} 
Minimum Cycle Life \\
\end{tabular} & Cycles & 200 & 10 & NA & 1,300 & 300 & NA \\
\hline Nominal Cycle Life & Cycles & 400 & 100 & 2,250 & 2,500 & 500 & NA \\
\hline \begin{tabular}{|l} 
Maximum Cycle Life \\
\end{tabular} & Cycles & 1,100 & 250 & NA & 3,500 & 1,500 & NA \\
\hline Mimimum Calendar Life & years & 3.0 & 0.5 & NA & 5.0 & 1.0 & NA \\
\hline \begin{tabular}{|l} 
Nominal Calendar Life \\
\end{tabular} & years & 5.5 & 1.0 & 7.5 & 7.0 & 3.0 & NA \\
\hline \begin{tabular}{|l} 
Maximum Calendar Life \\
\end{tabular} & years & 8.0 & 1.5 & 15.0 & 9.0 & 5.0 & NA \\
\hline Technology Cost & $\$ / k W h$ & 150 & 600 & 300 & 220 & 300 & NA \\
\hline Cost Relative to $\mathrm{Pb}$ Acid & none & 1.0 & 4.0 & 1.5 & 1.5 & 2.0 & NA \\
\hline
\end{tabular}




\section{Operating Voltage (V)}

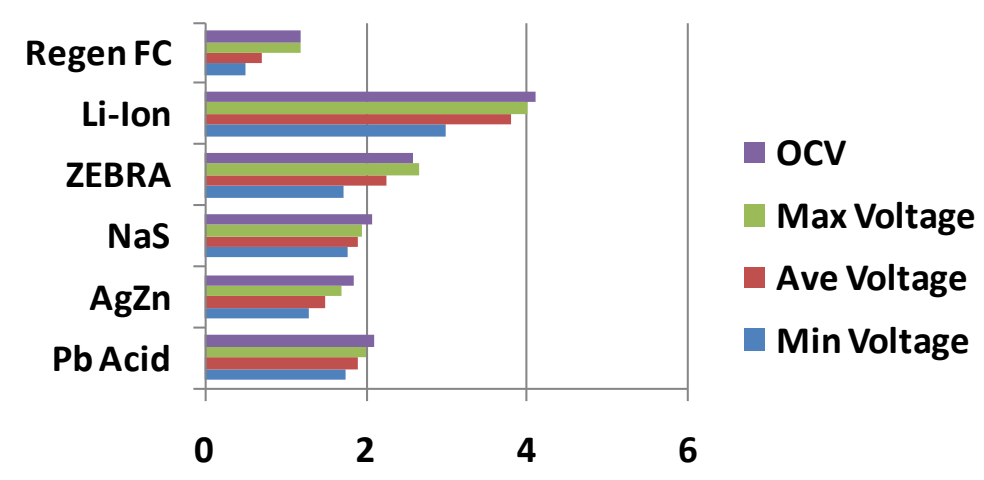

Figure F 1 - Range of cell voltages for energy storage technologies considered for the various hybrid energy conversion and storage systems, ranging from the open circuit voltage (OCV) to the minimum operating voltage

\section{Operating Temperature $\left({ }^{\circ} \mathrm{C}\right)$}

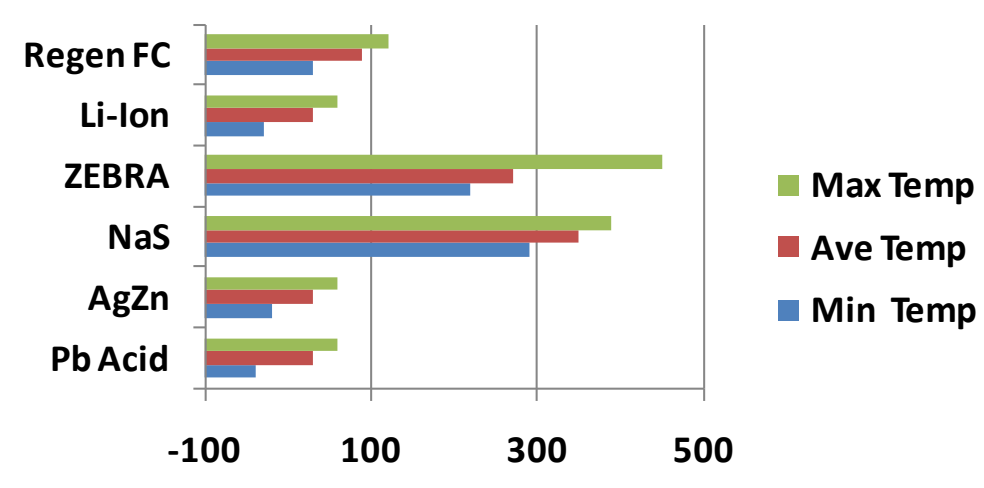

Figure $\mathrm{F} 2$ - Range of operating temperatures possible with the energy storage technologies considered for the various hybrid energy conversion and storage systems

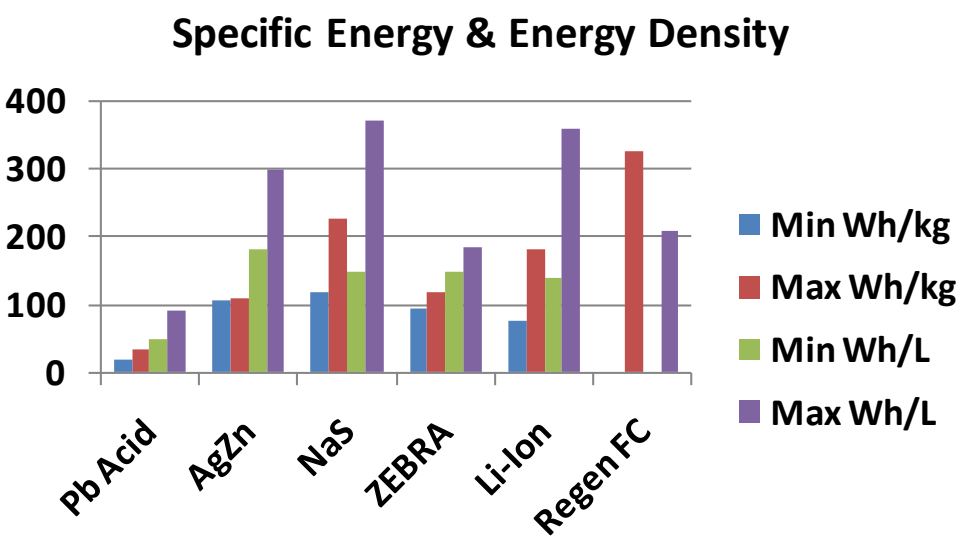

Figure $\mathrm{F} 3$ - A comparison of the specific energies and energy densities for the energy storage technologies considered for the various hybrid energy conversion and storage systems 


\section{Specific Power \& Power Density}

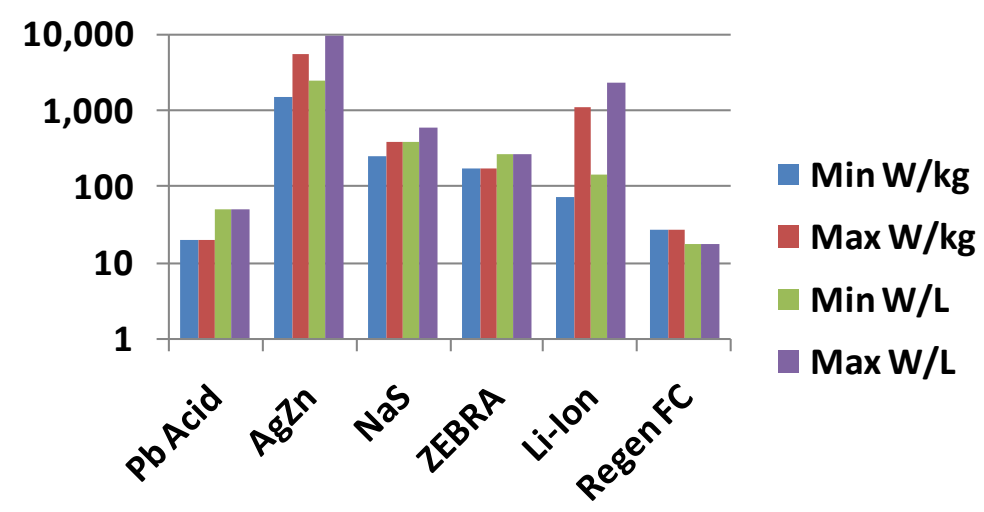

Figure F 4-A comparison of the specific powers and power densities for the energy storage technologies considered for the various hybrid energy conversion and storage systems

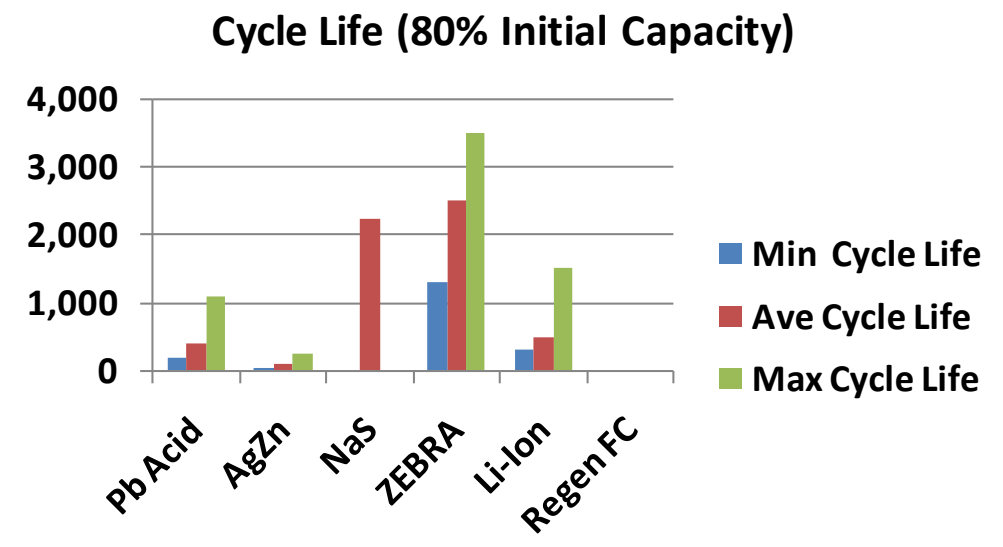

Figure F 5 - A comparison of the charge-discharge cycle lives for the energy storage technologies considered for the various hybrid energy conversion and storage systems

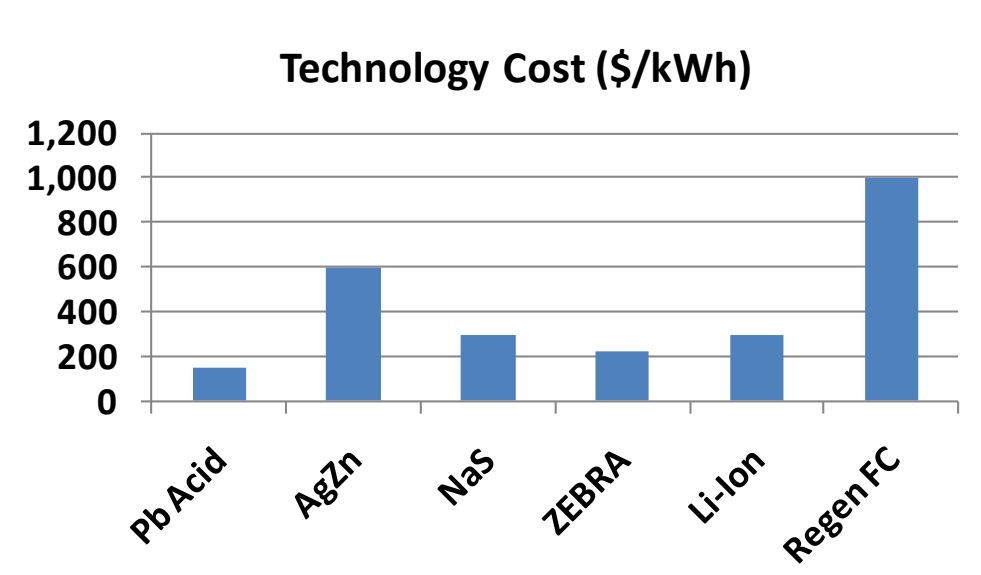

Figure F 6 - A comparison of the cost of energy storage for each of the technologies considered for the various hybrid energy conversion and storage systems 
Appendix G - Tradeoff Between Specific Energy \& Specific Power

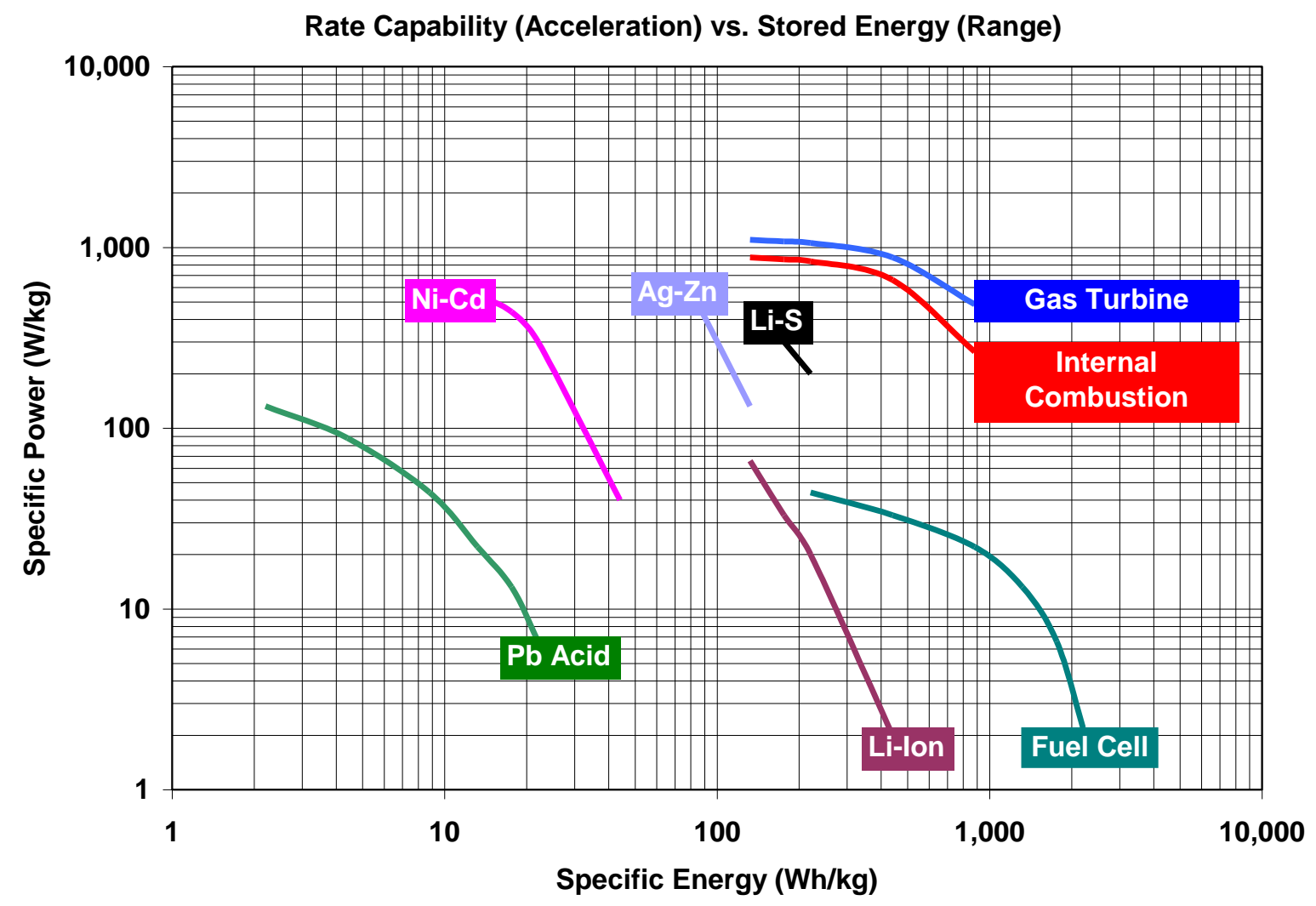

Figure G 1 - Specific power vs. specific energy for competing non-nuclear sub sea energy conversion and storage systems 


\section{Appendix $\mathrm{H}$ - Summary of Assumptions Underlying Economic Analysis}

Table H 1 - Life, interest rate, discount factor, and annuity factor assumptions [Perry's Handbook]

\begin{tabular}{|l|r|l|}
\hline Cost Model Assumptions & Value & Units \\
\hline Required Power & Site Specific & MW-e \\
\hline Service Life $=\mathrm{n}$ & 15 & years \\
\hline Interest Rate $=\mathrm{I}$ (Assuming Relatively Low Risk) & 5 \\
\hline Compound Interest Factor $=\mathrm{f}_{\mathrm{i}}=(1+\mathrm{i})^{\mathrm{n}}$ & 2.0789 & factor \\
\hline Discount Factor $=\mathrm{f}_{\mathrm{d}}=1 / \mathrm{f}_{\mathrm{i}}$ & 0.4810 & factor \\
\hline Annuity Future Worth Factor $=\mathrm{f}_{\mathrm{AF}}=\mathrm{A} / \mathrm{F}=\mathrm{i} /\left[(1+\mathrm{i})^{\mathrm{n}}-1\right]$ & 0.0463 & factor \\
\hline Annuity Present Worth Factor $=\mathrm{f}_{\mathrm{AP}}=\mathrm{A} / \mathrm{P}=\left[\mathrm{i}(1+\mathrm{i})^{\mathrm{n}}\right] /[(1+\mathrm{i}) \mathrm{n}-1]$ & 0.0963 & factor \\
\hline Salary \& Fringe Benefits - Management & 300000 & $\$ /$ year \\
\hline Salary \& Fringe Benefits - Engineer & 200000 & $\$ /$ year \\
\hline Salary \& Fringe Benefits - Operations & 100000 & $\$$ /year \\
\hline
\end{tabular}

\section{Table $\mathrm{H} 2$ - Miscellaneous assumptions impacting ocean floor grid option}

\begin{tabular}{|c|c|c|}
\hline Assumed Electrical Grid Concept of Operations & Parameter & Units \\
\hline Assumed Cost of DC Cables (Onshore to Control Buoy) & $2,500,000.00$ & US \$ per km \\
\hline Assumed Cost of HVDC Station & $30,000,000.00$ & US \$ per HVDC Station \\
\hline Assumed Power Capability of HVDC Station & 40.00 & MW per HVDC Station \\
\hline Assumed Cost of Umbilical Riser at Buoy & $1,000,000.00$ & US \$ per $1000 \mathrm{ft}$ \\
\hline Assumed Cost of Remote Control Buoy Station + AD/DC Inverter & $1,000,000.00$ & US \$ per unit \\
\hline \begin{tabular}{|l|} 
Assumed Cable Diameter \\
\end{tabular} & 4.0000 & inches \\
\hline Assumed Cable Diameter & 10.1600 & $\mathrm{~cm}$ \\
\hline Assumed Cable Diameter - Corresponding Cross-Sectional Area & 81.0732 & $\mathrm{~cm} 2$ \\
\hline Estimated Cable Volume Per km - Assumed Cable Diameter & $8,107,319.6656$ & $\mathrm{~cm} 3$ per $\mathrm{km}$ \\
\hline Assumed Cable Density Equals Copper Density & 8.9200 & grams per $\mathrm{cm} 3$ \\
\hline Estimated Cable Weight Per km - Assumed Cable Density & $72,317.2914$ & $\mathrm{~kg}$ per $\mathrm{km}$ \\
\hline Assumed Cost of Copper & 15.00 & US $\$$ per $\mathrm{kg}$ \\
\hline Assumed Cost of $\$ 1$ Million Per Kilometer - Estimated from Cable Size \& Copper Costs & $1,084,759.37$ & US \$ per km \\
\hline Assumed Cable Resistivity Equals Copper Resistivity at $20^{\circ}$ & 1.6730 & microohm-cm \\
\hline Assumed Cable Temperature Coefficient Equals Copper Temperature Coefficient & 0.0068 & per ${ }^{\circ} \mathrm{F}$ \\
\hline Assumed Cable Operating Temperature & 40.0000 & ${ }^{\circ} \mathrm{F}$ \\
\hline Assumed Cable Operating Temperature & 4.7778 & ${ }^{\circ} \mathrm{C}$ \\
\hline Assumed Cable Resistivity at Operating Temperature & 1.4998 & microohm-cm \\
\hline Assumed Cable Resistance per Kilometer & 0.0018 & ohms per km \\
\hline Conversion of Mechanical Horsepower (HP) to Watts (W) & 745.7000 & W per hp \\
\hline Assumed Pump Power & 800.0000 & hp per pump \\
\hline Assumed Pumps per ESP Unit & 2.0000 & pump per ESP \\
\hline Estimated Total Pumping Power per ESP Unit & 1.1931 & MW per ESP \\
\hline Assumed Cable Current - Two 800-HP Pumps Per ESP (230 Amps per Pump) & 460.0000 & amps per ESP \\
\hline Assumed Cable Current - Based Upon 70 MVA \& $120 \mathrm{KV}$ & 583.3333 & amps per site \\
\hline Assumed Nominal Cable Current & $1,000.0000$ & amps per site \\
\hline Assumed Cost of Electricity on Shore & 0.1000 & US \$ per kWh \\
\hline
\end{tabular}


Table $\mathrm{H} 3$ - Assumptions pertaining to the cost and operation of non-grid sub-systems

\begin{tabular}{|c|c|c|}
\hline Miscellaenous Assumptions & Parameter & Units \\
\hline Service Life & 15.00 & years \\
\hline Submersible on Bottom for 7 Days Between Surfacings & 168.00 & hours \\
\hline Assume Submersibles Operating in Parallel - One on Surface - One on Bottom & 2.00 & vehicles \\
\hline Vehicle to Power System Ratio & 1.25 & factor \\
\hline Fraction of Operating Power Required for Control \& Communications & 0.05 & fraction \\
\hline Full Power Backup Required for Graceful Shutdown - Operating Time on Battery & 4.00 & hours \\
\hline Cost of Cryogenic Oxygen at Surface & $0.50-0.75$ & LOX $\$$ per 100 SCF \\
\hline Cost of Cryogenic Oxygen at Surface & $0.50-0.75$ & LOX \$ per gal \\
\hline Cost of Cryogenic Oxygen at Surface & 0.198129 & LOX \$ per liter \\
\hline Density of Crygenic Oxygen at Surface & 1.149000 & LOS kg/L $\left(\mathrm{BP}=182.962^{\circ} \mathrm{C}\right)$ \\
\hline Cost of Cryogenic Oxygen at Surface & 0.172436 & LOX $\$$ per kg \\
\hline Cost of Cryogenic Oxygen at Surface & 0.172436 & $\mathrm{LOX} \$ / \mathrm{kg}$ \\
\hline Assumed Cost of Single Stand Pipe from Surface for Oxygen & $1,000,000.00$ & $\$$ per $1000 \mathrm{ft}$ \\
\hline \begin{tabular}{|l|l} 
Assumed Cost of Stand Pipe from Surface for Pressurized Oxygen \\
\end{tabular} & $1,000.00$ & $\$$ per ft \\
\hline Assumed Cost of Double Stand Pipe from Surface for Oxygen \& Exhaust & $2,000,000.00$ & $\$$ per $1000 \mathrm{ft}$ \\
\hline Assumed Cost of Double Stand Pipe from Surface for Oxygen \& Exhaust & $2,000.00$ & \$ per ft \\
\hline Pre-Exponential Factor for Carbon Steel PV \& FT Cost & 73.00 & $\$$ per kg \\
\hline Exponent for Carbon Steel PV \& FT Cost & -0.34 & none \\
\hline Escalation Factor for Titanium Fabrication & 11.00 & $\$(T i) / \$(C S)$ \\
\hline Hull Base Costs & 150000000.00 & $\$$ per unit \\
\hline Incremental Hull Costs & 8000.00 & $\$$ per metric ton \\
\hline Incremental Hull Costs & 8.00 & $\$$ per kg \\
\hline Reformer:Fuel Cell Weight Ratio & 2.00 & $\mathrm{~kg}$ per $\mathrm{kg}$ \\
\hline Reformer:Fuel Cell Volume Ratio & 2.00 & L per L \\
\hline Reformer:Fuel Cell Cost Ratio & 2.00 & $\$$ per $\$$ \\
\hline Reformer Efficiency & $90 \%$ & percent \\
\hline Fuel Cell Efficiency & $67 \%$ & percent \\
\hline Overall Efficiency for Reformer \& Fuel Cell System & $60 \%$ & percent \\
\hline Assumed Time to License Sub-Surface Nuclear Power Plant & 7.00 & years \\
\hline Assumed Licensing Costs Per Year & 3.00 & $\$ M$ per year \\
\hline
\end{tabular}

Table $\mathrm{H} 4$ - Cost factors applied to direct costs to calculate indirect and total overnight costs, and used to calculate the capital cost at the commencement of commercial operations, and the associated annualized costs

\begin{tabular}{|c|c|c|}
\hline RPSEA Concept of Operations Site: Site A & Factor & Units \\
\hline Energy Conversion \& Storage & Site/System Specific & \\
\hline Oxygen Supply & Site/System Specific & \\
\hline Pressure Vessels & Site/System Specific & \\
\hline Flotation Tanks & Site/System Specific & \\
\hline Miscellaneous & Site/System Specific & \\
\hline Direct Costs Subtotal $(2010 \$ \mathrm{M})$ & Site/System Specific & \\
\hline Construction Services & 0.10 & \\
\hline Home Office Engineering \& Services & 0.07 & \\
\hline Field Office Engineering \& Services & 0.05 & \\
\hline Owner's Costs & 0.13 & \\
\hline Licensing \& Permitting & 0.01 & \\
\hline \multicolumn{3}{|l|}{ Indirect Costs Subtotal (2010 \$M) } \\
\hline \multicolumn{3}{|l|}{ Total \& Indirect Costs $(2010 \$ \mathrm{M})$} \\
\hline Contingency Allowancy & 0.10 & \\
\hline Miscellaneous & 0.01 & \\
\hline \multicolumn{3}{|l|}{ Total Overnight Costs } \\
\hline Allowance for Escalation During Construction & 0.05 & \\
\hline Allowance for Interest & 0.05 & \\
\hline \multicolumn{3}{|l|}{ Capital Investment at Commercial Operation (2010 \$M) } \\
\hline Annualized Investment at Commercial Operation (2010 \$M/year) & 0.0963 & \\
\hline
\end{tabular}


Table $\mathrm{H} 5$ - Assumed labor and salaries for operation, and additional cost factors applied to the annualized investment to calculate various contributions to the annual operating expense

\begin{tabular}{|l|r|l|}
\hline RPSEA Concept of Operations Site: Site A & Manpower & Units \\
\hline Managers & FTE \\
\hline Engineers & 4 & FTE \\
\hline Operators & Factor & UTE \\
\hline RPSEA Concept of Operations Site: Site A & & \\
\hline Salaries \& Benefits & 0.10 & $\$ / \$$ \\
\hline Chemicals, Materials \& Utilities & 0.10 & $\$ / \$$ \\
\hline Spare Parts \& Capital Plant Upgrades & 0.10 & $\$ / \$$ \\
\hline Taxes \& Insurance & 0.05 & $\$ / \$$ \\
\hline Operating Cost Contingency & 0.02 & $\$ / \$$ \\
\hline General O\&M & $0.01 \$ / \$$ \\
\hline Miscellaneous & $\$$ \\
\hline
\end{tabular}




\section{Appendix I - Detailed Analyses of Costs for Each Concept of Operations Site}

\section{Table I 1 - Summary of the detailed economic analysis performed for the Shtokman site}

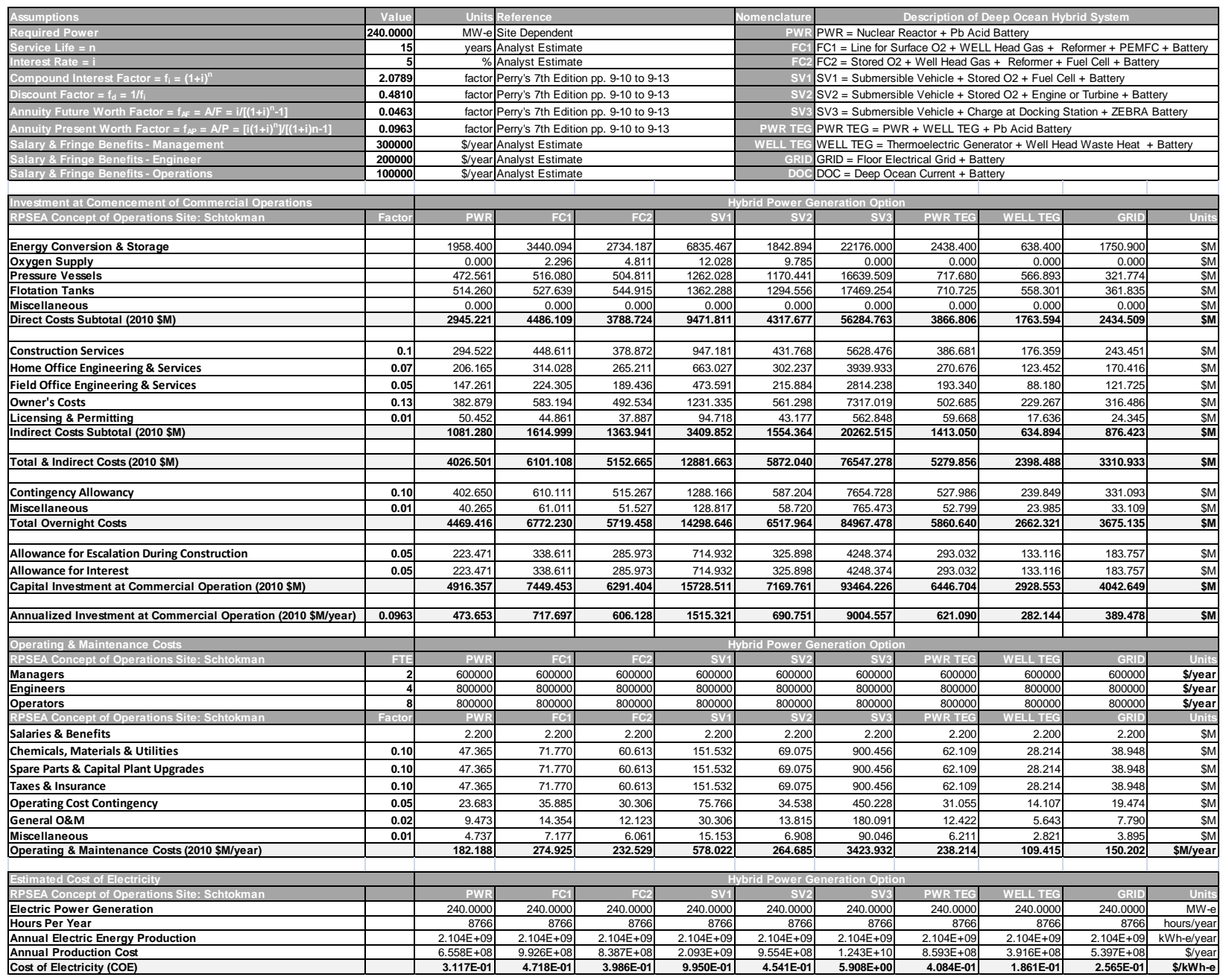


Table I 2 - Summary of the detailed economic analysis performed for the Chinook site

\begin{tabular}{|c|c|c|c|c|c|c|c|c|c|c|c|}
\hline Assumptions & Value & \multicolumn{4}{|c|}{ Units Reference } & Nomenclature & \multicolumn{5}{|c|}{ Description of Deep Ocean Hybrid System } \\
\hline Required Power & 7.2000 & \multirow{2}{*}{\multicolumn{4}{|c|}{$\begin{array}{l}\text { MW-e } \text { Site Dependent } \\
\text { years Analyst Estimate }\end{array}$}} & \multirow{2}{*}{\multicolumn{6}{|c|}{$\begin{array}{l}\text { PWR } P W R=\text { Nuclear Reactor }+ \text { Pb Acid Battery } \\
\text { FC1 } F C 1=\text { Line for Surface O2 + WELL Head Gas + Reformer + PEMFC + Battery }\end{array}$}} \\
\hline Service Life $=\mathrm{n}$ & 15 & & & & & & & & & & \\
\hline Interest Rate $=\mathrm{i}$ & 5 & \multicolumn{4}{|c|}{$\%$ Analyst Estimate } & & \multirow{2}{*}{\multicolumn{5}{|c|}{$\begin{array}{l}\text { FC2 = Stored O2 + Well Head Gas + Reformer + Fuel Cell + Battery } \\
\text { I1 SV1 = Submersible Vehicle + Stored O2 + Fuel Cell + Battery }\end{array}$}} \\
\hline Compound Interest Factor $=f_{i}=(1+i)^{n}$ & 2.0789 & \multirow{2}{*}{\multicolumn{4}{|c|}{ factor Perry's 7th Edition pp. 9-10 to 9-13 }} & & & & & & \\
\hline Discount Factor $=f_{d}=1 / f$ & 0.4810 & & & & & SV2 & \multicolumn{5}{|c|}{ SV2 $=$ Submersible Vehicle + Stored O2 + Engine or Turbine + Battery } \\
\hline Annuity Future Worth Factor $=f_{A F}=A / F=i /\left((1+i)^{n}-1\right]$ & 0.0463 & \multicolumn{4}{|c|}{ factor Perry's 7th Edition pp. 9-10 to 9-13 } & sv3 & \multicolumn{5}{|c|}{3 SV3 = Submersible Vehicle + Charge at Docking Station + ZEBRA Battery } \\
\hline Annuity Present Worth Factor $=f_{A P}=A / P=\left[(1+i)^{n} y /(1+i) n-1\right]$ & 0.0963 & factor & \multicolumn{3}{|c|}{ tor Perry's 7th Edition pp. 9-10 to 9-13 } & PWR TEG & \multicolumn{5}{|c|}{ PWR TEG = PWR + WELL TEG + Pb Acid Battery } \\
\hline Salary \& Fringe Benefits - Management & 300000 & \multirow{2}{*}{\multicolumn{4}{|c|}{$\begin{array}{l}\$ / \text { year } \text { Analyst Estimate } \\
\$ / \text { year } \text { Analyst Estimate }\end{array}$}} & WELL TEG & \multicolumn{5}{|c|}{ WELL TEG $=$ Thermoelectric Generator + Well Head Waste Heat + Battery } \\
\hline Salary \& Fringe Benefits - Engineer & 200000 & & & & & GRID & GRID $=$ Floor El & trical Grid + Bat & & & \\
\hline Salary \& Fringe Beneffits - Operations & 100000 & $\$ /$ year & Analyst Estimat & & & DOC & $\mathrm{DOC}=\mathrm{Deep} \mathrm{Oc}$ & in Current $+\mathrm{Ba}$ & & & \\
\hline$\sqrt{\text { Investment at Comencement of Commercial Operations }}$ & & & & & & id Power Gt & eneration Optic & & & & \\
\hline RPSEA Concept of Operations Site: Chinok & Factor & PWR & $\mathrm{FCl}$ & $\mathrm{FC} 2$ & SV1 & SV2 & SV3 & PWR TEG & WELL TEG & GRID & Units \\
\hline Energy Conversion \& Storage & & 58.752 & 1168.302 & 585.067 & 1462.668 & 97.638 & 665.280 & 73.152 & 19.152 & 83.002 & \$M \\
\hline Oxygen Supply & & 0.000 & 17.600 & 1.777 & 4.444 & 1.932 & 0.000 & 0.000 & 0.000 & 0.000 & $\$ \mathrm{SM}$ \\
\hline \begin{tabular}{|l|} 
Pressure Vessels \\
\end{tabular} & & 457.217 & 606.623 & 535.023 & 1337.558 & 1140.615 & 16043.725 & 635.339 & 485.052 & 306.930 & $\$ M$ \\
\hline Flotation Tanks & & 474.080 & 705.457 & $\begin{array}{ll}669.167 \\
\end{array}$ & 1672.917 & 1276.486 & 16485.470 & 659.524 & \begin{tabular}{|l|l|}
508.507 \\
\end{tabular} & 323.063 & $\$ \mathrm{M}$ \\
\hline Miscellaneous & & 0.000 & 0.000 & 0.000 & 0.000 & 0.000 & 0.000 & 0.000 & 0.000 & 0.000 & $\$ \mathrm{M}$ \\
\hline \begin{tabular}{|l} 
Direct Costs Subtotal (2010 \$M) \\
\end{tabular} & & 990.048 & 2497.982 & 1791.035 & 4477.587 & 2516.671 & 33194.476 & 1368.015 & 1012.711 & 712.995 & $\$ M$ \\
\hline & & & & & & & & & & & \\
\hline Construction Services & 0.1 & 99.005 & 249.798 & 179.103 & 447.759 & 251.667 & 3319.448 & 136.801 & 101.271 & 71.299 & $\$ \mathrm{M}$ \\
\hline Home Office Engineering \& Services & 0.07 & 69.303 & 174.859 & 125.372 & 313.431 & 176.167 & 2323.613 & 95.761 & 70.890 & 49.910 & $\$ \mathrm{M}$ \\
\hline Field Office Engineering \& Services & 0.05 & 49.502 & 124.899 & 89.552 & 223.879 & 125.834 & 1659.724 & 68.401 & 50.636 & 35.650 & $\$ M$ \\
\hline Owner's Costs & 0.13 & 128.706 & 324.738 & 232.835 & 582.086 & 327.167 & 4315.282 & 177.842 & 131.652 & 92.689 & $\$ M$ \\
\hline Licensing \& Permitting & 0.01 & 30.900 & 24.980 & 17.910 & 44.776 & 25.167 & 331.945 & 34.680 & 10.127 & 7.130 & $\$ \mathrm{M}$ \\
\hline Indirect Costs Subtotal (2010 \$M) & & 377.417 & 899.274 & 644.773 & 1611.931 & 906.001 & 11950.011 & 513.485 & 364.576 & 256.678 & $\$ M$ \\
\hline Total \& Indirect Costs (2010 \$M) & & 1367.466 & 3397.256 & 2435.808 & 6089.519 & 3422.672 & 45144.487 & 1881.500 & 1377.287 & 969.673 & $\$ M$ \\
\hline & & & & & & & & & & & \\
\hline Contingency Allowancy & 0.10 & 136.747 & 339.726 & 243.581 & 608.952 & 342.267 & 4514.449 & 188.150 & 137.729 & 96.967 & $\$ \mathrm{M}$ \\
\hline Miscellaneous & 0.01 & 13.675 & 33.973 & 24.358 & 60.895 & 34.227 & 451.445 & 18.815 & 13.773 & 9.697 & $\$ \mathrm{M}$ \\
\hline Total Overnight Costs & & 1517.887 & 3770.954 & 2703.746 & 6759.366 & 3799.166 & 50110.380 & 2088.465 & 1528.788 & 1076.337 & $\$ M$ \\
\hline & & & & & & & & & & & \\
\hline Allowance for Escalation During Construction & 0.05 & 75.894 & 188.548 & 135.187 & 337.968 & 189.958 & 2505.519 & 104.423 & 76.439 & 53.817 & $\$ \mathrm{M}$ \\
\hline \begin{tabular}{|l|l|} 
Allowance for Interest \\
\end{tabular} & 0.05 & 75.894 & 188.548 & 135.187 & 337.968 & 189.958 & 2505.519 & 104.423 & 76.439 & 53.817 & $\$ \mathrm{M}$ \\
\hline Capital Investment at Commercial Operation $(2010 \$ \mathrm{M})$ & & 1669.676 & 4148.050 & 2974.121 & 7435.302 & 4179.082 & 55121.418 & 2297.311 & 1681.667 & 1183.971 & $\$ M$ \\
\hline Annualized Investment at Commercial Operation (2010 \$M/year) & 0.0963 & 160.860 & 399.633 & 286.534 & 716.334 & 402.622 & 5310.524 & 221.328 & 162.016 & 114.066 & $\$ M$ \\
\hline & & & & & & & & & & & \\
\hline RPSEA Concept of Operations Site: Chinok & FTE & PWR & $\mathrm{FC1}$ & $\mathrm{FC} 2$ & SV1 & SV2 & 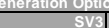 & PWR TEG & WELLL TEG & GRID & Units \\
\hline Managers & 2 & 600000 & 600000 & 600000 & 600000 & 600000 & 600000 & 600000 & 600000 & 600000 & \$/year \\
\hline Engineers & $\frac{4}{4}$ & 800000 & 800000 & 800000 & 800000 & 800000 & 800000 & 800000 & 800000 & 800000 & $\$$ \$year \\
\hline Operators & 8 & 800000 & 800000 & 800000 & 800000 & 800000 & 800000 & 800000 & 800000 & 800000 & $\$ /$ year \\
\hline RPSEA Concept of Operations Site: Chinok & Factor & PWR & $\mathrm{FC1}$ & $\mathrm{FC2}$ & SV1 & SV2 & SV3 & PWR TEG & WELL TEG & GRID & Units \\
\hline Salaries \& Benefits & & 2.200 & 2.200 & 2.200 & 2.200 & 2.200 & 2.200 & 2.200 & 2.200 & 2.200 & $\$ \mathrm{M}$ \\
\hline Chemicals, Materials \& Utilities & 0.10 & 16.086 & 39.963 & 28.653 & 71.633 & 40.262 & 531.052 & 22.133 & 16.202 & 11.407 & $\$ \mathrm{M}$ \\
\hline Spare Parts \& Capital Plant Upgrades & 0.10 & 16.086 & 39.963 & 28.653 & 71.633 & 40.262 & 531.052 & 22.133 & 16.202 & 11.407 & $\$ \mathrm{M}$ \\
\hline Taxes \& Insurance & 0.10 & 16.086 & 39.963 & 28.653 & 71.633 & 40.262 & 531.052 & 22.133 & 16.202 & 11.407 & $\$ \mathrm{M}$ \\
\hline Operating Cost Contingency & 0.05 & 8.043 & 19.982 & 14.327 & 35.817 & 20.131 & 265.526 & 11.066 & 8.101 & 5.703 & $\$ \mathrm{M}$ \\
\hline General O\&M & 0.02 & 3.217 & 7.993 & 5.731 & 14.327 & 8.052 & 106.210 & 4.427 & 3.240 & 2.281 & $\$ M$ \\
\hline Miscellaneous & 0.01 & 1.609 & 3.996 & 2.865 & 7.163 & 4.026 & 53.105 & 2.213 & 1.620 & 1.141 & $\$ \mathrm{M}$ \\
\hline Operating \& Maintenance Costs (2010 \$M/year) & & 63.327 & 154.060 & 111.083 & 274.407 & 155.196 & 2020.199 & 86.305 & 63.766 & 45.545 & $\$ M /$ year \\
\hline Estimated Cost of Electricity & & & & & & Power G: & ation Optic & & & & \\
\hline RPSEA Concept of Operations Site: Chinok & & PWR & FC1 & $\mathrm{FC} 2$ & SV1 & SV2 & SVB & PWR TEE & WELL TEG & GRID & Units \\
\hline Electric Power Generation & & 7.2000 & 7.2000 & 7.2000 & 7.2000 & 7.2000 & 7.2000 & 7.2000 & 7.2000 & 7.2000 & MW-e \\
\hline Hours Per Year & & 8766 & 8766 & 8766 & 8766 & 8766 & 8766 & 8766 & 8766 & 8766 & hours/year \\
\hline Production & & $312 \mathrm{E}+07$ & $312 \mathrm{E}+07$ & $12 \mathrm{E}+07$ & $2 \mathrm{E}+07$ & $2 \mathrm{E}+07$ & $2 \mathrm{E}+07$ & $312 \mathrm{E}+07$ & $6.312 \mathrm{E}+07$ & $6.312 \mathrm{E}+07$ & kWh-e/year \\
\hline Annual Production Cost & & $2.242 \mathrm{E}+08$ & $5.537 \mathrm{E}+08$ & $3.976 \mathrm{E}+08$ & $9.907 \mathrm{E}+08$ & $5.578 \mathrm{E}+08$ & $7.331 E+09$ & $3.076 \mathrm{E}+08$ & $2.258 \mathrm{E}+08$ & $1.596 \mathrm{E}+08$ & \$/year \\
\hline Cost of Electricity (COE) & & $3.552 \mathrm{E}+00$ & $8.773 \mathrm{E}+00$ & $6.300 \mathrm{E}+00$ & $1.570 \mathrm{E}+01$ & $8.838 \mathrm{E}+00$ & $1.161 \mathrm{E}+02$ & $4.874 \mathrm{E}+00$ & $3.577 \mathrm{E}+00$ & $2.529 \mathrm{E}+00$ & \$/kWh-e \\
\hline
\end{tabular}


Table I 3 - Summary of the detailed economic analysis performed for the King site

\begin{tabular}{|c|c|c|c|c|c|c|c|c|c|c|c|}
\hline Assumptions & Value & Units & \multirow{2}{*}{\multicolumn{3}{|c|}{ Reference }} & Nomenclature & \multicolumn{5}{|c|}{ Description of Deep Ocean Hybrid System } \\
\hline Required Power & 2.0000 & MW-e & \multirow{2}{*}{\multicolumn{3}{|c|}{\begin{tabular}{|l} 
Site Dependent \\
Analyst Estimate
\end{tabular}}} & \multicolumn{6}{|c|}{ PWR PWR $=$ Nuclear Reactor $+\mathrm{Pb}$ Acid Battery } \\
\hline Service Life $=\mathrm{n}$ & 15 & years & & & & \multicolumn{6}{|c|}{$\begin{array}{l}\text { PWR } P \text { PWR = Nuclear Reactor + Pb Acid Battery } \\
\text { FC1 FC1 = Line for Surface O2 + WELL Head Gas + Reformer + PEMFC + Battery }\end{array}$} \\
\hline Interest Rate $=\mathrm{i}$ & 5 & $\%$ & \multicolumn{3}{|l|}{ Analyst Estimate } & $\mathrm{FC2}$ & \multicolumn{5}{|c|}{ F2 F2 = Stored O2 + Well Head Gas + Reformer + Fuel Cell + Battery } \\
\hline Compound Interest Factor $=f_{i}=(1+i)^{n}$ & 2.0789 & factor & \multicolumn{3}{|c|}{ Perry's 7th Edition pp. 9-10 to 9-13 } & svi 1 & \multicolumn{5}{|c|}{ SV1 = Submersible Vehicle + Stored O2 + Fuel Cell + Battery } \\
\hline Discount Factor $=f_{d}=1 / f$ & 0.4810 & factor & \multicolumn{3}{|c|}{ Perry's 7th Edition pp. 9-10 to 9-13 } & $\mathrm{sv}_{2}$ & \multicolumn{5}{|c|}{ SV2 $=$ Submersible Vehicle + Stored O2 + Engine or Turbine + Battery } \\
\hline Annuity Future Worth Factor $=f_{A F}=A / F=i /\left[(1+i)^{n}-1\right]$ & 0.0463 & factor & \multicolumn{3}{|c|}{ Perry's 7th Edition pp. 9-10 to 9-13 } & sv3 & \multicolumn{5}{|c|}{ SV3 $=$ Submersible Vehicle + Charge at Docking Station + ZEBRA Battery } \\
\hline Annuity Present Worth Factor $\left.=f_{A P}=A / P=\left[(1+i)^{n}\right] /(1+i) n-1\right]$ & 0.0963 & factor & \multicolumn{3}{|c|}{ Perry's 7th Edition pp. 9-10 to 9-13 } & PWR TEG & PWR TEG $=$ PW & R + WELL TEG & b Acid Batter & & \\
\hline Salary \& Fringe Benefits - Management & 300000 & $\$ /$ year & Analyst Estimate & & & WELL TEG & WELL TEG $=$ Th & imoelectric Gen & tor + Well $\mathrm{He}$ & Waste Heat + & + Battery \\
\hline Salary \& Fringe Benefits - Engineer & 200000 & \$/year & Analyst Estimate & & & GRID & GRID $=$ Floor Ele & ctrical Grid + Bat & & & \\
\hline Salary \& Fringe Benefits - Operations & 100000 & $\$$ \$year & Analyst Estimate & & & DOC & DOC $=$ Deep Oce & an Current + Bat & & & \\
\hline Investment at Comencement of Commercial Operations & & & & & & lybrid Power Gt & eneration Optio & & & & \\
\hline RPSEA Concept of Operations Site: King & Factor & PWR & FC1 & FC2 & SV1 & SV2 & SV3 3 & PWR TEG & WELLL TEG & GRID & Units \\
\hline Energy Conversion \& Storage & & 16.320 & 80.547 & 47.287 & 118.218 & 18.706 & 184.800 & 20.320 & 5.320 & 81.320 & $\$$ \\
\hline Oxygen Supply & & 0.000 & 11.156 & $\begin{array}{l}0.120 \\
0.120\end{array}$ & 0.299 & 0.211 & 0.000 & 0.000 & 0.000 & 0.000 & $\$ \mathrm{M}$ \\
\hline \begin{tabular}{|l|} 
Pressure Vessels \\
\end{tabular} & & 451.825 & 460.555 & 457.028 & 1142.571 & 1128.989 & 15826.947 & 608.266 & 458.183 & 301.742 & $\$ M$ \\
\hline Flotation Tanks & & 455.414 & 464.765 & 464.689 & 1161.722 & 1145.749 & 15921.278 & 611.759 & 461.485 & 305.140 & $\$ \mathrm{M}$ \\
\hline \begin{tabular}{|l|} 
Miscellaneous \\
\end{tabular} & & 0.000 & 0.000 & 0.000 & 0.000 & 0.000 & 0.000 & 0.000 & 0.000 & 0.000 & $\$ \mathrm{M}$ \\
\hline Direct Costs Subtotal (2010 \$M) & & 923.559 & 1017.022 & 969.124 & 2422.811 & 2293.655 & $\begin{array}{ll}31933.025 \\
\end{array}$ & 1240.345 & $\begin{array}{ll}924.988 \\
\end{array}$ & 688.202 & $\$ M$ \\
\hline & & & & & & & & & & & \\
\hline Construction Services & 0.1 & 92.356 & 101.702 & 96.912 & 242.281 & 229.365 & 3193.303 & 124.035 & 92.499 & 68.820 & $\$ \mathrm{M}$ \\
\hline Home Office Engineering \& Services & 0.07 & 64.649 & 71.192 & 67.839 & 169.597 & 160.556 & 2235.312 & 86.824 & 64.749 & 48.174 & $\$ \mathrm{M}$ \\
\hline Field Office Engineering \& Services & 0.05 & 46.178 & 50.851 & 48.456 & 121.141 & 114.683 & 1596.651 & 62.017 & 46.249 & 34.410 & $\$ M$ \\
\hline Owner's Costs & 0.13 & 120.063 & 132.213 & 125.986 & 314.965 & 298.175 & 4151.293 & 161.245 & 120.249 & 89.466 & $\$ M$ \\
\hline Licensing \& Permitting & 0.01 & 30.236 & 10.170 & 9.691 & 24.228 & 22.937 & 319.330 & 33.403 & 9.250 & 6.882 & $\$ \mathrm{M}$ \\
\hline Indirect Costs Subtotal (2010 \$M) & & 353.481 & 366.128 & 348.885 & 872.212 & 825.716 & \begin{tabular}{ll|l}
11495.889 \\
\end{tabular} & 467.524 & 332.996 & 247.753 & $\$ M$ \\
\hline Total \& Indirect Costs (2010 \$M) & & 1277.040 & 1383.150 & \begin{tabular}{ll|}
1318.009 \\
\end{tabular} & 3295.022 & 3119.370 & \begin{tabular}{ll|l}
43428.915 & $r$
\end{tabular} & 1707.870 & 1257.984 & 935.955 & $\$ M$ \\
\hline & & & & & & & & & & & \\
\hline Contingency Allowancy & 0.10 & 127.704 & 138.315 & 131.801 & 329.502 & 311.937 & 4342.891 & 170.787 & 125.798 & 93.596 & $\$ \mathrm{M}$ \\
\hline \begin{tabular}{|l|} 
Miscellaneous \\
\end{tabular} & 0.01 & 12.770 & 13.832 & 13.180 & 32.950 & 31.194 & 434.289 & 17.079 & 12.580 & 9.360 & $\$ \mathrm{M}$ \\
\hline Total Overnight Costs & & 1417.515 & 1535.297 & 1462.990 & 3657.475 & 3462.501 & 48206.095 & 1895.735 & 1396.363 & 1038.910 & $\$ \mathrm{M}$ \\
\hline & & & & & & & & & & & \\
\hline Allowance for Escalation During Construction & 0.05 & 70.876 & 76.765 & 73.149 & 182.874 & 173.125 & 2410.305 & 94.787 & 69.818 & 51.946 & $\$ \mathrm{M}$ \\
\hline Allowance for Interest & 0.05 & 70.876 & 76.765 & 73.149 & 182.874 & 173.125 & 2410.305 & 94.787 & 69.818 & 51.946 & $\$ \mathrm{M}$ \\
\hline Capital Investment at Commercial Operation $(2010 \$ M)$ & & 1559.266 & 1688.827 & 1609.289 & 4023.222 & 3808.751 & 53026.705 & 2085.309 & 1535.999 & 1142.801 & $\$ M$ \\
\hline Annualized Investment at Commercial Operation (2010 \$M/year) & 0.0963 & 150.223 & 162.705 & 155.043 & 387.606 & 366.944 & 5108.714 & 200.903 & 147.982 & 110.100 & $\$ M$ \\
\hline & & & & & & & & & & & \\
\hline Operating \& Maintenance Costs & & & & & & id Power G & eneration Optio & & & & \\
\hline RPSEA Concept of Operations Site: King & FTE & PWR & FC1 & $\mathrm{FC2}$ & SV1 & SV2 & SV3 & PWR TEG & WELL TEG & GRID & Units \\
\hline Managers & 2 & 600000 & 600000 & 600000 & 600000 & 600000 & 600000 & & 600000 & 600000 & \$/year \\
\hline Engineers & 4 & 800000 & 800000 & 800000 & 800000 & 800000 & 800000 & 800000 & 800000 & 800000 & \$/year \\
\hline Operators & 8 & 800000 & 800000 & 800000 & 800000 & 800000 & 800000 & 800000 & 800000 & 800000 & $\$ /$ year \\
\hline RPSEA Concept of Operations Site: King & Factor & PWR & FC1 & $\mathrm{FC2}$ & SV1 & SV2 & SV3 & PWR TEG & WELL TEG & GRID & Units \\
\hline Salaries \& Benefits & & 2.200 & 2.200 & 2.200 & 2.200 & 2.200 & 2.200 & 2.200 & 2.200 & 2.200 & $\$ \mathrm{M}$ \\
\hline Chemicals, Materials \& Utilities & 0.10 & 15.022 & 16.271 & 15.504 & 38.761 & 36.694 & 510.871 & 20.090 & 14.798 & 11.010 & $\$ \mathrm{M}$ \\
\hline Spare Parts \& Capital Plant Upgrades & 0.10 & 15.022 & 16.271 & 15.504 & 38.761 & 36.694 & 510.871 & 20.090 & 14.798 & 11.010 & $\$ \mathrm{M}$ \\
\hline Taxes \& Insurance & 0.10 & 15.022 & 16.271 & \begin{tabular}{l|l}
15.504 \\
\end{tabular} & 38.761 & 36.694 & 510.871 & 20.090 & 14.798 & 11.010 & $\$ \mathrm{M}$ \\
\hline Operating Cost Contingency & 0.05 & 7.511 & 8.135 & \begin{tabular}{l|l}
7.752 \\
\end{tabular} & 19.380 & 18.347 & 255.436 & 10.045 & 7.399 & 5.505 & $\$ \mathrm{M}$ \\
\hline General O\&M & 0.02 & 3.004 & 3.254 & 3.101 & 7.752 & 7.339 & 102.174 & 4.018 & 2.960 & 2.202 & $\$ \mathrm{M}$ \\
\hline Miscellaneous & 0.01 & 1.502 & 1.627 & 1.550 & 3.876 & 3.669 & & 2.009 & 1.480 & 1.101 & $\$ \mathrm{M}$ \\
\hline Operating \& Maintenance Costs (2010 \$M/year) & & 59.285 & 64.028 & 61.116 & 149.490 & 141.639 & 1943.511 & 78.543 & 58.433 & 44.038 & $\$ M /$ year \\
\hline st of Electricity & & & & & & Power G: & ration Optio & & & & \\
\hline of Operations Site: King & & PWR & $\mathrm{FCl}$ & $\mathrm{FC2}$ & SV1 & SV2 & SV3 & PWR TEG & WELL TEG & GRID & Units \\
\hline Electric Power & & 2.0000 & 2.0000 & 2.0000 & 2.0000 & 2.0000 & 2.0000 & 2.0000 & 2.0000 & 2.0000 & MW-e \\
\hline Hours Per Year & & 8766 & 8766 & 8766 & 8766 & 8766 & 8766 & 8766 & 8766 & 8766 & hours/year \\
\hline ergy Production & & $1.753 \mathrm{E}+07$ & $1.753 \mathrm{E}+07$ & $1.753 \mathrm{E}+07$ & $1.753 \mathrm{E}+07$ & $1.753 \mathrm{E}+07$ & $1.753 \mathrm{E}+07$ & $1.753 \mathrm{E}+07$ & $1.753 \mathrm{E}+07$ & $1.753 \mathrm{E}+07$ & kWh-e/year \\
\hline Annual Production Cost & & $2.095 \mathrm{E}+08$ & $2.267 \mathrm{E}+08$ & $2.162 \mathrm{E}+08$ & $5.371 \mathrm{E}+08$ & $5.086 \mathrm{E}+08$ & $7.052 \mathrm{E}+09$ & $2.794 \mathrm{E}+08$ & $2.064 \mathrm{E}+08$ & $1.541 E+08$ & \$/year \\
\hline Cost of Electricity (COE) & & 1.195E+01 & $1.293 \mathrm{E}+01$ & $1.233 \mathrm{E}+01$ & $3.064 \mathrm{E}+01$ & $2.901 \mathrm{E}+01$ & $4.022 E+02$ & $1.594 \mathrm{E}+01$ & $1.177 \mathrm{E}+01$ & $8.792 \mathrm{E}+00$ & $\$ / k W h-e$ \\
\hline
\end{tabular}


Table I 4 - Summary of the detailed economic analysis performed for the Ormen Lange site

\begin{tabular}{|c|c|c|c|c|c|c|c|c|c|c|c|}
\hline Assumptions & Value & Units & \multicolumn{3}{|l|}{ Reference } & Nomenclature & \\
\hline Required Power & 60.0000 & MW-e & \multirow{2}{*}{\multicolumn{3}{|c|}{\begin{tabular}{|l|} 
Site Dependent \\
Analyst Estimate \\
\end{tabular}}} & \multirow{2}{*}{\multicolumn{6}{|c|}{$\begin{array}{l}\text { PWR } / \text { PWR }=\text { Nuclear Reactor }+ \text { Pb Acid Battery } \\
\text { FC1 FC1 }=\text { Line for Surface O2 + WELL Head Gas + Reformer + PEMFC + Battery }\end{array}$}} \\
\hline Service Life $=\mathrm{n}$ & 15 & years & & & & & & & & & \\
\hline Interest Rate $=\mathrm{i}$ & 5 & & & $\mathrm{FC}_{2} \mathrm{~F}$ & \multicolumn{5}{|c|}{ FC2 $=$ Stored O2 + Well Head Gas + Reformer + Fuel Cell + Battery } \\
\hline Compound Interest Factor $=f_{i}=(1+i)^{n}$ & 2.0789 & factor & \multicolumn{3}{|c|}{ Perry's 7th Edition pp. 9-10 to 9-13 } & SV1: & \multicolumn{5}{|c|}{ SV1 $=$ Submersible Vehicle + Stored O2 + Fuel Cell + Battery } \\
\hline Discount Factor $=f_{d}=1 / f_{i}$ & 0.4810 & factor & \multicolumn{3}{|c|}{ Perry's 7th Edition pp. 9-10 to 9-13 } & $\mathrm{sV} 2 \mathrm{~s}$ & \multicolumn{5}{|c|}{ SV2 $=$ Submersible Vehicle + Stored O2 + Engine or Turbine + Battery } \\
\hline Annuity Future Worth Factor $=\mathrm{f}_{\mathrm{AF}}=\mathrm{A} / \mathrm{F}=\mathrm{i} /\left[(1+\mathrm{i})^{n}-1\right]$ & 0.0463 & factor & \multicolumn{3}{|c|}{ Perry's 7th Edition pp. 9-10 to 9-13 } & SV3 & \multicolumn{5}{|c|}{ SV3 $=$ Submersible Vehicle + Charge at Docking Station + ZEBRA Battery } \\
\hline Annuity Present Worth Factor $=f_{A P}=A / P=\left[(1+i)^{n} y /(1+i) n-1\right]$ & 0.0963 & factor & \multicolumn{3}{|c|}{ Perry's 7th Edition pp. 9-10 to 9-13 } & PWR TEG & PWR TEG = PW & R + WELL TEG & b Acid Batter & & \\
\hline Salary \& Fringe Benefits - Management & 300000 & $\$ / y e a r$ & Analyst Estimate & & & WELL TEG & WELL TEG $=$ The & moelectric Gen & tor + Well $\mathrm{He}$ & Waste Heat + & Battery \\
\hline Salary \& Fringe Benefits - Engineer & 200000 & $\$ /$ year & Analyst Estimate & & & GRID & GRID $=$ Floor Eles & ctrical Grid + Bat & & & Datury \\
\hline Salary \& Fringe Benefits - Operations & 100000 & $\$ / y e a r$ & Analyst Estimate & & & $\mathrm{DOC}[\mathrm{L}$ & DOC $=$ Deep Oce & an Current + Bat & & & \\
\hline Investment at Comencement of Commercial Operations & & & & & & id Power Ge & eneration Option & & & & \\
\hline RPSEA Concept of Operations Site: Ormen Lange & Factor & PWR & FC1 & $\mathrm{FC}_{2}$ & SV1 & SV2 & SV3 & PWR TEG & WELL TEG & GRID & Units \\
\hline & & & & & & & & & & & \\
\hline Energy Conversion \& Storage & & 489.600 & 1257.904 & 871.464 & 2178.659 & 489.211 & 5544.000 & 609.600 & 159.600 & 384.600 & $\$ \mathrm{M}$ \\
\hline Oxygen Supply & & 0.000 & 5.578 & 1.813 & 4.532 & 3.549 & 0.000 & 0.000 & 0.000 & 0.000 & $\$ \mathrm{M}$ \\
\hline \begin{tabular}{|l|} 
Pressure Vessels \\
\end{tabular} & & 465.109 & 509.538 & 494.091 & 1235.227 & 1155.894 & 16352.419 & 677.129 & 526.576 & 314.556 & $\$ \mathrm{M}$ \\
\hline Flotation Tanks & & 496.718 & 525.714 & 535.152 & 1337.881 & 1262.244 & 17067.394 & 690.481 & 538.598 & 344.834 & $\$ \mathrm{M}$ \\
\hline Miscellaneous & & 0.000 & 0.000 & 0.000 & 0.000 & 0.000 & 0.000 & 0.000 & 0.000 & 0.000 & $\$ \mathrm{M}$ \\
\hline Direct Costs Subtotal (2010 \$M) & & 1451.427 & 2298.734 & 1902.520 & 4756.299 & 2910.898 & 38963.814 & 1977.210 & 1224.774 & 1043.991 & $\$ \mathrm{M}$ \\
\hline & & & & & & & & & & & \\
\hline Construction Services & 0.1 & 145.143 & 229.873 & 190.252 & 475.630 & 291.090 & 3896.381 & 197.721 & 122.477 & 104.399 & $\$ \mathrm{M}$ \\
\hline Home Office Engineering \& Services & 0.07 & 101.600 & 160.911 & 133.176 & 332.941 & 203.763 & 2727.467 & 138.405 & 85.734 & 73.079 & $\$ \mathrm{M}$ \\
\hline Field Office Engineering \& Services & 0.05 & 72.571 & 114.937 & 95.126 & 237.815 & 145.545 & 1948.191 & 98.861 & 61.239 & 52.200 & $\$ \mathrm{M}$ \\
\hline Owner's Costs & 0.13 & 188.686 & 298.835 & 247.328 & 618.319 & 378.417 & 5065.296 & 257.037 & 159.221 & 135.719 & $\$ \mathrm{M}$ \\
\hline Licensing \& Permitting & 0.01 & 35.514 & 22.987 & 19.025 & $\begin{array}{r}47.563 \\
\end{array}$ & 29.109 & 389.638 & 40.772 & 12.248 & 10.440 & $\$ \mathrm{M}$ \\
\hline Indirect Costs Subtotal (2010 \$M) & & 543.514 & 827.544 & 684.907 & 1712.268 & $\begin{array}{ll}1047.923 \\
\end{array}$ & 14026.973 & 732.796 & 440.919 & 375.837 & $\$ \mathrm{M}$ \\
\hline & & & & & & & & & & & \\
\hline Total \& Indirect Costs $(2010 \$ \mathrm{M})$ & & 1994.941 & 3126.278 & $\begin{array}{l}2587.427 \\
\end{array}$ & $\begin{array}{ll}6468.567 \\
\end{array}$ & 3958.821 & 52990.787 & 2710.006 & 1665.692 & 1419.827 & \$M \\
\hline & & & & & & & & & & & \\
\hline Contingency Allowancy & 0.10 & 199.494 & 312.628 & 258.743 & 646.857 & 395.882 & 5299.079 & 271.001 & 166.569 & 141.983 & $\$ \mathrm{M}$ \\
\hline Miscellaneous & 0.01 & 19.949 & 31.263 & 25.874 & 64.686 & 39.588 & 529.908 & 27.100 & 16.657 & 14.198 & $\$ \mathrm{M}$ \\
\hline Total Overnight Costs & & 2214.384 & 3470.169 & 2872.044 & 7180.109 & 4394.292 & 58819.774 & 3008.106 & 1848.918 & 1576.008 & $\$ \mathrm{M}$ \\
\hline Allowance for Escalation During Construction & 0.05 & 110.719 & 173.508 & 143.602 & 359.005 & 219.715 & 2940.989 & 150.405 & 92.446 & 78.800 & $\$ \mathrm{M}$ \\
\hline \begin{tabular}{|l|l|} 
Allowance for Interest \\
\end{tabular} & 0.05 & 110.719 & 173.508 & 143.602 & 359.005 & 219.715 & 2940.989 & 150.405 & 92.446 & 78.800 & $\$ \mathrm{M}$ \\
\hline Capital Investment at Commercial Operation (2010\$M) & & 2435.823 & 3817.186 & 3159.248 & 7898.120 & 4833.721 & 64701.751 & 3308.917 & 2033.810 & 1733.609 & $\$ \mathrm{M}$ \\
\hline Annualized Investment at Commercial Operation (2010 \$M/year) & 0.0963 & 234.673 & 367.756 & 304.369 & 760.923 & 465.692 & 6233.515 & 318.789 & 195.942 & 167.020 & $\$ \mathrm{M}$ \\
\hline & & & & & & & & & & & \\
\hline Operat & & & & & & Power G: & ration Option & & & & \\
\hline RPSEA Concept of Operations Site: Ormen Lange & FTE & PWR & FC1 & $\mathrm{FC} 2$ & SV1 & SV2 & SV3 & PWR TEG & WELL TEG & GRID & Units \\
\hline Managers & 2 & 600000 & 600000 & 600000 & 600000 & 600000 & 600000 & 600000 & 600000 & 600000 & \$/year \\
\hline Engineers & 4 & 800000 & 800000 & 800000 & 800000 & 800000 & 800000 & 800000 & 800000 & 800000 & \$/year \\
\hline Operators & 8 & 800000 & 800000 & 800000 & 800000 & 800000 & 800000 & 800000 & 800000 & 800000 & $\$ /$ year \\
\hline RPSEA Concept of Operations Site: Ormen Lange & Factor & PWR & $\mathrm{FC1}$ & $\mathrm{FC}_{2}$ & SV1 & SV2 & SV3 & PWR TEG & WELL TEG & GRID & Units \\
\hline Salaries \& Benefits & & 2.200 & 2.200 & 2.200 & 2.200 & 2.200 & 2.200 & 2.200 & 2.200 & 2.200 & $\$ M$ \\
\hline Chemicals, Materials \& Utilities & 0.10 & 23.467 & 36.776 & 30.437 & 76.092 & 46.569 & 623.351 & 31.879 & 19.594 & 16.702 & $\$ \mathrm{M}$ \\
\hline Spare Parts \& Capital Plant Upgrades & 0.10 & 23.467 & 36.776 & 30.437 & 76.092 & 46.569 & 623.351 & 31.879 & 19.594 & 16.702 & $\$ \mathrm{M}$ \\
\hline Taxes \& Insurance & 0.10 & 23.467 & 36.776 & 30.437 & 76.092 & 46.569 & 623.351 & 31.879 & 19.594 & 16.702 & $\$ \mathrm{M}$ \\
\hline Operating Cost Contingency & 0.05 & 11.734 & 18.388 & 15.218 & 38.046 & 23.285 & 311.676 & 15.939 & 9.797 & 8.351 & $\$ \mathrm{M}$ \\
\hline General O\&M & 0.02 & 4.693 & 7.355 & 6.087 & 15.218 & 9.314 & 124.670 & 6.376 & 3.919 & 3.340 & $\$ \mathrm{M}$ \\
\hline Miscellaneous & 0.01 & 2.347 & 3.678 & 3.044 & 7.609 & 4.657 & 62.335 & 3.188 & 1.959 & 1.670 & $\$ \mathrm{M}$ \\
\hline Operating \& Maintenance Costs (2010 \$M/year) & & 91.376 & 141.947 & 117.860 & 291.351 & 179.163 & 2370.936 & 123.340 & 76.658 & 65.668 & \$M/year \\
\hline Estimat. & & & & & & Power Ge & ation Option & & & & \\
\hline RPSEA Concept of Operations Site: Ormen Lange & & PWR & $\mathrm{FC1}$ & $\mathrm{FC2}$ & svi & SV2 & SV3 & PWR TEG & WELL TEG & GRID & Units \\
\hline Electric Power Generation & & 60.0000 & 60.0000 & 60.0000 & 60.0000 & 60.0000 & 60.0000 & 60.0000 & 60.0000 & 60.0000 & MW-e \\
\hline Hours Per Year & & 8766 & 8766 & 8766 & 8766 & 8766 & 8766 & 8766 & 8766 & 8766 & hours/year \\
\hline Annual Electric Energy Production & & $5.260 \mathrm{E}+08$ & $5.260 \mathrm{E}+08$ & $5.260 \mathrm{E}+08$ & $5.260 E+08$ & $5.260 E+08$ & $5.260 \mathrm{E}+08$ & $5.260 \mathrm{E}+08$ & $5.260 \mathrm{E}+08$ & $5.260 \mathrm{E}+08$ & kWh-e/year \\
\hline Annual Production Cost & & $3.260 \mathrm{E}+08$ & $5.097 \mathrm{E}+08$ & $4.222 \mathrm{E}+08$ & $1.052 \mathrm{E}+09$ & $6.449 \mathrm{E}+08$ & $8.604 \mathrm{E}+09$ & $4.421 \mathrm{E}+08$ & $2.726 \mathrm{E}+08$ & $2.327 E+08$ & \$/year \\
\hline Cost of Electricity (COE) & & 6.199E-01 & $9.691 \mathrm{E}-01$ & $8.028 \mathrm{E}-01$ & $2.001 E+00$ & $\frac{0.445+60}{1.226 \mathrm{E}+00}$ & $1.636 \mathrm{E}+01$ & $8.406 \mathrm{E}-01$ & $5.183 \mathrm{E}-01$ & 4.424E-01 & $\$ /$ kWh-e \\
\hline
\end{tabular}


Table I 5 - Summary of the detailed economic analysis performed for the Perdido site

\begin{tabular}{|c|c|c|c|c|c|c|c|c|c|c|c|}
\hline Assumptions & Value & Units & \multirow{2}{*}{\multicolumn{3}{|c|}{ Reference }} & Nomenclature & \multicolumn{5}{|c|}{ Description of Deep Ocean Hybrid System } \\
\hline Required Power & 5.0000 & MW-e & \multirow{2}{*}{\multicolumn{3}{|c|}{\begin{tabular}{|l|} 
Site Dependent \\
Analyst Estimate
\end{tabular}}} & \\
\hline Service Life $=\mathrm{n}$ & 15 & years & & & & \multicolumn{6}{|c|}{$\begin{array}{l}\text { PWR } \mathrm{PWR}=\text { Nuclear Reactor }+ \text { Pb Acid Battery } \\
\text { FC1 } F C 1=\text { Line for Surface O2 + WELL Head Gas + Reformer + PEMFC + Battery }\end{array}$} \\
\hline Interest Rate $=\mathrm{i}$ & 5 & $\%$ & \multicolumn{3}{|l|}{ Analyst Estimate } & $\mathrm{FC} 2$ & \multicolumn{5}{|c|}{ FC2 = Stored O2 + Well Head Gas + Reformer + Fuel Cell + Battery } \\
\hline Compound Interest Factor $=f_{i}=(1+i)^{n}$ & 2.0789 & factor & \multicolumn{3}{|c|}{ Perry's 7th Edition pp. 9-10 to 9-13 } & svi 1 & \multicolumn{5}{|c|}{ SV1 = Submersible Vehicle + Stored O2 + Fuel Cell + Battery } \\
\hline Discount Factor $=f_{d}=1 / f$ & 0.4810 & factor & \multicolumn{3}{|c|}{ Perry's 7th Edition pp. 9-10 to 9-13 } & $\mathrm{sv}_{2}$ & \multicolumn{5}{|c|}{ SV2 $=$ Submersible Vehicle + Stored O2 + Engine or Turbine + Battery } \\
\hline Annuity Future Worth Factor $=f_{A F}=A / F=i /\left[(1+i)^{n}-1\right]$ & 0.0463 & factor & \multicolumn{3}{|c|}{ Perry's 7th Edition pp. 9-10 to 9-13 } & sv3 & \multicolumn{5}{|c|}{ SV3 $=$ Submersible Vehicle + Charge at Docking Station + ZEBRA Battery } \\
\hline Annuity Present Worth Factor $\left.=f_{A P}=A / P=\left[(1+i)^{n}\right] /(1+i) n-1\right]$ & 0.0963 & factor & \multicolumn{3}{|c|}{ Perry's 7th Edition pp. 9-10 to 9-13 } & PWR TEG & PWR TEG $=$ PW & $R+$ WELL TEG & b Acid Batter & & \\
\hline Salary \& Fringe Benefits - Management & 300000 & $\$ /$ year & Analyst Estimate & & & WELL TEG & WELL TEG $=$ Th & ermoelectric Gen & tor + Well $\mathrm{He}$ & Waste Heat + & + Battery \\
\hline Salary \& Fringe Benefits - Engineer & 200000 & \$/year & Analyst Estimate & & & GRID & GRID $=$ Floor Ele & ctrical Grid + Bat & & & \\
\hline Salary \& Fringe Benefits - Operations & 100000 & $\$$ \$year & Analyst Estimate & & & DOC & DOC $=$ Deep Oce & ean Current + Bat & & & \\
\hline Investment at Comencement of Commercial Operations & & & & & & lybrid Power Gt & eneration Optio & & & & \\
\hline RPSEA Concept of Operations Site: Perdito & Factor & PWR & FC1 & FC2 & SV1 & SV2 & SV3 3 & PWR TEG & WELL TEG & GRID & Units \\
\hline Energy Conversion \& Storage & & 40.800 & 483.110 & 251.284 & 628.211 & 59.013 & 462.000 & 50.800 & 13.300 & 283.300 & $\$$ \\
\hline Oxygen Supply & & 0.000 & 15.998 & 0.731 & 1.828 & $\frac{00.0102}{1.002}$ & 0.000 & 0.000 & 0.000 & 0.000 & $\$ \mathrm{M}$ \\
\hline \begin{tabular}{|l|} 
Pressure Vessels \\
\end{tabular} & & 454.976 & 515.348 & 487.509 & 1218.772 & 1135.772 & 15954.585 & 623.852 & 473.646 & 304.770 & $\$ M$ \\
\hline Flotation Tanks & & 465.645 & 551.875 & 540.987 & 1352.466 & 1209.053 & 16228.744 & 637.058 & 486.372 & 314.959 & $\$ \mathrm{M}$ \\
\hline \begin{tabular}{|l|} 
Miscellaneous \\
\end{tabular} & & 0.000 & 0.000 & 0.000 & 0.000 & 0.000 & 0.000 & 0.000 & 0.000 & 0.000 & $\$ \mathrm{M}$ \\
\hline Direct Costs Subtotal (2010 \$M) & & 961.421 & 1566.331 & 1280.511 & 3201.277 & 2404.840 & 32645.330 & 1311.710 & $\begin{array}{l}973.318 \\
\end{array}$ & 903.029 & $\$ M$ \\
\hline & & & & & & & & & & & \\
\hline Construction Services & 0.1 & 96.142 & 156.633 & 128.051 & 320.128 & 240.484 & 3264.533 & 131.171 & 97.332 & 90.303 & $\$ \mathrm{M}$ \\
\hline Home Office Engineering \& Services & 0.07 & 67.299 & 109.643 & 89.636 & 224.089 & 168.339 & 2285.173 & 91.820 & 68.132 & 63.212 & $\$ \mathrm{M}$ \\
\hline Field Office Engineering \& Services & 0.05 & 48.071 & 78.317 & 64.026 & 160.064 & 120.242 & 1632.266 & 65.585 & 48.666 & 45.151 & $\$ M$ \\
\hline Owner's Costs & 0.13 & 124.985 & 203.623 & 166.466 & 416.166 & 312.629 & 4243.893 & 170.522 & 126.531 & 117.394 & $\$ M$ \\
\hline Licensing \& Permitting & 0.01 & 30.614 & 15.663 & 12.805 & 32.013 & 24.048 & \begin{tabular}{|l|l|}
326.453 \\
\end{tabular} & 34.117 & 9.733 & 9.030 & $\$ \mathrm{M}$ \\
\hline Indirect Costs Subtotal (2010 \$M) & & 367.111 & 563.879 & 460.984 & 1152.460 & 865.742 & 11752.319 & 493.216 & 350.395 & 325.090 & $\$ M$ \\
\hline Total \& Indirect Costs (2010 \$M) & & 1328.532 & 2130.210 & $\begin{array}{l}1741.495 \\
\end{array}$ & 4353.737 & 3270.582 & 44397.648 & 1804.925 & 1323.713 & 1228.119 & $\$ M$ \\
\hline & & & & & & & & & & & \\
\hline Contingency Allowancy & 0.10 & 132.853 & 213.021 & 174.149 & 435.374 & 327.058 & 4439.765 & 180.493 & 132.371 & 122.812 & $\$ \mathrm{M}$ \\
\hline \begin{tabular}{|l|} 
Miscellaneous \\
\end{tabular} & 0.01 & 13.285 & 21.302 & 17.415 & 43.537 & 32.706 & 443.976 & 18.049 & 13.237 & 12.281 & $\$ \mathrm{M}$ \\
\hline Total Overnight Costs & & 1474.671 & 2364.533 & 1933.059 & 4832.648 & 3630.346 & 49281.390 & 2003.467 & 1469.321 & 1363.212 & $\$ \mathrm{M}$ \\
\hline & & & & & & & & & & & \\
\hline Allowance for Escalation During Construction & 0.05 & 73.734 & 118.227 & 96.653 & 241.632 & 181.517 & 2464.069 & 100.173 & 73.466 & 68.161 & $\$ M$ \\
\hline Allowance for Interest & 0.05 & 73.734 & 118.227 & 96.653 & 241.632 & 181.517 & 2464.069 & 100.173 & 73.466 & 68.161 & $\$ M$ \\
\hline Capital Investment at Commercial Operation $(2010 \$ M)$ & & 1622.138 & 2600.986 & 2126.365 & 5315.913 & 3993.381 & 54209.529 & 2203.814 & 1616.253 & 1499.534 & \$M \\
\hline Annualized Investment at Commercial Operation (2010 \$M/year) & 0.0963 & 156.280 & 250.585 & 204.859 & 512.147 & 384.731 & 5222.670 & 212.320 & 155.714 & 144.468 & $\$ M$ \\
\hline & & & & & & & & & & & \\
\hline Operating \& Maintenance Costs & & & & & & d Power G & eneration Optio & & & & \\
\hline RPSEA Concept of Operations Site: Perdito & FTE & PWR & FC1 & $\mathrm{FC2}$ & SV1 & SV2 & SV3 & PWR TEG & WELL TEG & GRID & Units \\
\hline Managers & 2 & 600000 & 600000 & 600000 & 600000 & 600000 & 600000 & 600000 & 600000 & 600000 & \$/year \\
\hline Engineers & 4 & 800000 & 800000 & 800000 & 800000 & 800000 & 800000 & 800000 & 800000 & 800000 & \$/year \\
\hline Operators & 8 & 800000 & 800000 & 800000 & 800000 & 800000 & 800000 & 800000 & 800000 & 800000 & $\$ /$ year \\
\hline RPSEA Conce pt of Operations Site: Perdito & Factor & PWR & FC1 & $\mathrm{FC2}$ & SV1 & SV2 & SV3 & PWR TEG & WELL TEG & GRID & Units \\
\hline Salaries \& Benefits & & 2.200 & 2.200 & 2.200 & 2.200 & 2.200 & 2.200 & 2.200 & 2.200 & 2.200 & $\$ \mathrm{M}$ \\
\hline Chemicals, Materials \& Utilities & 0.10 & 15.628 & 25.058 & 20.486 & 51.215 & 38.473 & 522.267 & 21.232 & 15.571 & 14.447 & $\$ \mathrm{M}$ \\
\hline Spare Parts \& Capital Plant Upgrades & 0.10 & 15.628 & 25.058 & 20.486 & 51.215 & 38.473 & 522.267 & 21.232 & 15.571 & 14.447 & $\$ \mathrm{M}$ \\
\hline Taxes \& Insurance & 0.10 & 15.628 & 25.058 & 20.486 & 51.215 & 38.473 & 522.267 & 21.232 & 15.571 & 14.447 & $\$ \mathrm{M}$ \\
\hline Operating Cost Contingency & 0.05 & 7.814 & 12.529 & 10.243 & 25.607 & 19.237 & 261.134 & 10.616 & 7.786 & 7.223 & $\$ \mathrm{M}$ \\
\hline General O\&M & 0.02 & 3.126 & 5.012 & 4.097 & 10.243 & 7.695 & 104.453 & 4.246 & 3.114 & 2.889 & $\$ \mathrm{M}$ \\
\hline Miscellaneous & 0.01 & 1.563 & 2.506 & 2.049 & 5.121 & 3.847 & & 2.123 & 1.557 & 1.445 & $\$ \mathrm{M}$ \\
\hline Operating \& Maintenance Costs (2010 \$M/year) & & 61.587 & $\begin{array}{ll}97.422 \\
\end{array}$ & 80.046 & 196.816 & 148.398 & 1986.815 & 82.882 & 61.371 & 57.098 & $\$ M /$ year \\
\hline Estimated Cost of Electricity & & & & & & ower G: & ation Optio & & & & \\
\hline of Operations Site: Perdito & & PWR & $\mathrm{FCl}$ & $\mathrm{FC2}$ & SV1 & SV2 & SV3 & PWR TEG & WELL TEG & GRID & Units \\
\hline Electric Power & & 5.0000 & 5.0000 & 5.0000 & 5.0000 & 5.0000 & 5.0000 & 5.0000 & 5.0000 & 5.0000 & MW-e \\
\hline Hours Per Year & & 8766 & 8766 & 8766 & 8766 & 8766 & 8766 & 8766 & 8766 & 8766 & hours/year \\
\hline ergy Production & & $4.383 \mathrm{E}+07$ & $4.383 \mathrm{E}+07$ & $4.383 \mathrm{E}+07$ & $4.383 \mathrm{E}+07$ & $4.383 \mathrm{E}+07$ & $4.383 E+07$ & $4.383 \mathrm{E}+07$ & $4.383 \mathrm{E}+07$ & $4.383 \mathrm{E}+07$ & kWh-e/year \\
\hline Annual Production Cost & & $2.179 \mathrm{E}+08$ & $3.480 \mathrm{E}+08$ & $2.849 \mathrm{E}+08$ & $7.090 \mathrm{E}+08$ & $5.331 \mathrm{E}+08$ & $7.209 \mathrm{E}+09$ & $2.952 \mathrm{E}+08$ & $2.171 \mathrm{E}+08$ & $2.016 \mathrm{E}+08$ & \$/year \\
\hline Cost of Electricity (COE) & & $4.971 \mathrm{E}+00$ & $7.940 E+00$ & $6.500 \mathrm{E}+00$ & $1.618 \mathrm{E}+01$ & $1.216 \mathrm{E}+01$ & $1.645 \mathrm{E}+02$ & $6.735 E+00$ & $4.953 \mathrm{E}+00$ & $4.599 \mathrm{E}+00$ & $\$ / k W h-e$ \\
\hline
\end{tabular}


Table I 6 - Summary of the detailed economic analysis performed for the Argonauta site

\begin{tabular}{|c|c|c|c|c|c|c|c|c|c|c|c|}
\hline Assumptions & Value & Units & \multicolumn{3}{|l|}{ Reference } & \multirow{2}{*}{ Nomenclature } & \\
\hline Required Power & 2.2000 & MW-e & \multirow{2}{*}{\multicolumn{3}{|c|}{$\begin{array}{l}\text { Site Dependent } \\
\text { Analyst Estimate }\end{array}$}} & \multirow{2}{*}{\multicolumn{6}{|c|}{$\begin{array}{l}\text { PW/ PWR }=\text { Nuclear Reaccor + Pb Acid Battery } \\
\text { FC1 FC1 = Line for Surface O2 + WELL Head Gas + Reformer + PEMFC + Battery }\end{array}$}} \\
\hline Service Life $=\mathrm{n}$ & 15 & years & & & & & & & & & \\
\hline Interest Rate $=\mathrm{i}$ & 5 & $\%$ & \multicolumn{3}{|l|}{ Analyst Estimate } & FC2 & \multicolumn{5}{|c|}{$\begin{array}{l}1 \text { 1FC1 }=\text { Line for Surface O2 + WELL Head Gas + Reformer + PEMFC + Battery } \\
2 \text { FC2 }=\text { Stored O2 + Well Head Gas + Reformer + Fuel Cell + Battery }\end{array}$} \\
\hline Compound Interest Factor $=f_{i}=(1+i)^{n}$ & 2.0789 & factor & \multicolumn{3}{|c|}{ Perry's 7th Edition pp. 9-10 to 9-13 } & svi & \multicolumn{5}{|c|}{ SV1 = Submersible Vehicle + Stored O2 + Fuel Cell + Battery } \\
\hline Discount Factor $=f_{d}=1 / f$ & 0.4810 & factor & \multicolumn{3}{|c|}{ Perry's 7th Edition pp. 9-10 to 9-13 } & sv2 & \multicolumn{5}{|c|}{ SV2 $=$ Submersible Vehicle + Stored O2 + Engine or Turbine + Battery } \\
\hline Annuity Future Worth Factor $=\mathrm{f}_{\mathrm{A} F}=\mathrm{A} / \mathrm{F}=\mathrm{i} /\left[(1+i)^{\mathrm{n}}-1\right]$ & 0.0463 & factor & \multicolumn{3}{|c|}{ Perry's 7th Edition pp. 9-10 to 9-13 } & SV3 & \multicolumn{5}{|c|}{ SV3 $=$ Submersible Vehicle + Charge at Docking Station + ZEBRA Battery } \\
\hline Annuity Present Worth Factor $\left.\left.=I_{A P}=A / P=[(1+i))^{n}\right] /(1+i) n-1\right]$ & 0.0963 & factor & \multicolumn{3}{|c|}{ Perry's 7th Edition pp. 9-10 to 9-13 } & PWR TEG & PWR TEG = PW & $\mathrm{R}+\mathrm{WELL}$ TEG & $\mathrm{Pb}$ Acid Batter & & \\
\hline Salary \& Fringe Beneffits - Management & 300000 & \$/year & Analyst Estimate & & & WELLL TEG & WELL TEG $=$ The & ermoelectric Gen & rator + Well $\mathrm{He}$ & Waste Heat & + Battery \\
\hline Salary \& Fringe Beneffits - Engineer & 200000 & $\$ /$ year & Analyst Estimate & & & GRID & GRID = Floor Eles & ctrical Grid $+\mathrm{Bat}$ & & & \\
\hline Salary \& Fringe Benefits - Operations & 100000 & $\$ /$ year & Analyst Estimate & & & DOC & DOC $=$ Deep Oce & an Current + Bat & & & \\
\hline Investment at Comencement of Commercial Operations & & & & & & wer G: & eneration Option & & & & \\
\hline RPSEA Concept of Operations Site: Argonauta & Factor & PWR & $\mathrm{FC1}$ & $\mathrm{FC}_{2}$ & SV1 & SV2 & \begin{tabular}{|l|l|}
$\mathrm{SV}_{3}$ \\
\end{tabular} & PWR TEG & WELL TEG & GRID & Units \\
\hline Energy Conversion \& Storage & & 17.952 & 106.917 & 60.666 & 151.666 & 21.560 & 203.280 & 22.352 & 5.852 & 53.952 & $\$ \mathrm{M}$ \\
\hline Oxygen Supply & & 0.000 & 12.468 & 0.160 & 0.399 & 0.270 & 0.000 & 0.000 & 0.000 & 0.000 & $\$ \mathrm{M}$ \\
\hline \begin{tabular}{|l|l|} 
Pressure Vessels \\
\end{tabular} & & 452.145 & 464.580 & 459.368 & 1148.421 & 1129.685 & 15840.088 & 609.801 & 459.705 & 302.049 & $\$ \mathrm{M}$ \\
\hline Flotation Tanks & & 456.575 & 471.000 & 470.338 & 1175.846 & 1151.618 & $\begin{array}{l}15958.499 \\
\end{array}$ & 614.736 & 464.408 & 306.248 & $\$ M$ \\
\hline Miscellaneous & & 0.000 & 0.000 & 0.000 & 0.000 & 0.000 & 0.000 & 0.000 & 0.000 & 0.000 & $\$ M$ \\
\hline Direct Costs Subtotal (2010 \$M) & & 926.672 & 1054.965 & 990.533 & 2476.332 & 2303.133 & 32001.868 & 1246.889 & 929.966 & 662.248 & \$M \\
\hline Construction Services & 0.1 & 92.667 & 105.497 & 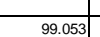 & 247.633 & 230.313 & 3200.187 & 124.689 & 92.997 & 66.225 & $\$ \mathrm{M}$ \\
\hline Home Office Engineering \& Services & 0.07 & 64.867 & 73.848 & 69.337 & 173.343 & 161.219 & 2240.131 & 87.282 & 65.098 & 46.357 & $\$ \mathrm{M}$ \\
\hline Field Office Engineering \& Services & 0.05 & 46.334 & 52.748 & 49.527 & 123.817 & 115.157 & 1600.093 & 62.344 & 46.498 & 33.112 & $\$ \mathrm{M}$ \\
\hline Owner's Costs & 0.13 & 120.467 & 137.146 & 128.769 & 321.923 & 299.407 & 4160.243 & 162.096 & 120.896 & 86.092 & $\$ \mathrm{M}$ \\
\hline Licensing \& Permitting & 0.01 & 30.267 & 10.550 & 9.905 & 24.763 & 23.031 & 320.019 & 33.469 & 9.300 & 6.622 & $\$ \mathrm{M}$ \\
\hline Indirect Costs Subtotal (2010 \$M) & & 354.602 & 379.788 & 356.592 & 891.480 & 829.128 & 11520.672 & 469.880 & 334.788 & 238.409 & $\$ M$ \\
\hline Total \& Indirect Costs (2010 \$M) & & 1281.274 & 1434.753 & 1347.125 & 3367.812 & 3132.261 & 43522.540 & 1716.770 & 1264.753 & 900.657 & $\$ \mathrm{M}$ \\
\hline & & & & & & & & & & & \\
\hline Contingency Allowancy & 0.10 & 128.127 & 143.475 & 134.712 & 336.781 & 313.226 & 4352.254 & 171.677 & 126.475 & 90.066 & $\$ M$ \\
\hline \begin{tabular}{|l|} 
Miscellaneous \\
\end{tabular} & 0.01 & 12.813 & 14.348 & 13.471 & 33.678 & 31.323 & 435.225 & 17.168 & 12.648 & 9.007 & $\$ \mathrm{M}$ \\
\hline Total Overnight Costs & & 1422.214 & 1592.576 & 1495.308 & 3738.271 & 3476.810 & 48310.019 & 1905.614 & 1403.876 & 999.730 & $\$ M$ \\
\hline Allowance for Escalation During Construction & 0.05 & 71.111 & 79.629 & 74.765 & 186.914 & 173.840 & 2415.501 & 95.281 & 70.194 & 49.986 & $\$ \mathrm{M}$ \\
\hline Allowance for Interest & 0.05 & 71.111 & 79.629 & 74.765 & 186.914 & 173.840 & 2415.501 & 95.281 & 70.194 & 49.986 & $\$ M$ \\
\hline Capital Investment at Commercial Operation $(2010 \$ M)$ & & 1564.435 & 1751.833 & 1644.839 & 4112.098 & 3824.491 & 53141.021 & 2096.176 & 1544.264 & 1099.703 & $\$ M$ \\
\hline Annualized Investment at Commercial Operation (2010\$M/year) & 0.0963 & 150.721 & 168.776 & 158.468 & 396.169 & 368.460 & 5119.728 & 201.950 & 148.778 & 105.948 & $\$ M$ \\
\hline & & & & & & & & & & & \\
\hline Operating \& Maintenance Costs & & & & & & Power Gt & eneration Option & & & & \\
\hline RPSEA Concept of Operations Site: Argonauta & FTE & PWR & FC1 & FC2 & SV1 & SV2 & \begin{tabular}{|r|}
$S_{3} V_{3}$ \\
\end{tabular} & PWR TEG & WELL TEG & GRID & Units \\
\hline Managers & 2 & 600000 & 600000 & 600000 & 600000 & 600000 & 600000 & 600000 & 600000 & 600000 & \$/year \\
\hline Engineers & 4 & 800000 & 800000 & 800000 & 800000 & 800000 & 800000 & 800000 & 800000 & 800000 & \$/year \\
\hline \begin{tabular}{|l|} 
Operators \\
\end{tabular} & 8 & 800000 & 800000 & 800000 & 800000 & 800000 & 800000 & 800000 & 800000 & 800000 & \$/year \\
\hline RPSEA Concept of Operations Site: Argonauta & Factor & PWR & FC1 & $\mathrm{FC} 2$ & SV1 & SV2 & SV3 & PWR TEG & WELL TEG & GRID & \\
\hline Salaries \& Benefits & & 2.200 & 2.200 & 2.200 & 2.200 & 2.200 & 2.200 & 2.200 & 2.200 & 2.200 & $\$ \mathrm{M}$ \\
\hline Chemicals, Materials \& Utilities & 0.10 & 15.072 & 16.878 & 15.847 & 39.617 & 36.846 & 511.973 & 20.195 & 14.878 & 10.595 & $\$ \mathrm{M}$ \\
\hline Spare Parts \& Capital Plant Upgrades & 0.10 & 15.072 & 16.878 & 15.847 & 39.617 & 36.846 & 511.973 & 20.195 & 14.878 & 10.595 & $\$ \mathrm{M}$ \\
\hline Taxes \& Insurance & 0.10 & 15.072 & 16.878 & 15.847 & 39.617 & 36.846 & 511.973 & 20.195 & 14.878 & 10.595 & $\$ \mathrm{M}$ \\
\hline Operating Cost Contingency & 0.05 & 7.536 & 8.439 & 7.923 & 19.808 & 18.423 & 255.986 & 10.098 & 7.439 & 5.297 & $\$ \mathrm{M}$ \\
\hline General O\&M & 0.02 & 3.014 & 3.376 & 3.169 & 7.923 & 7.369 & 102.395 & 4.039 & 2.976 & 2.119 & $\$ \mathrm{M}$ \\
\hline Miscellaneous & 0.01 & 1.507 & 1.688 & 1.585 & 3.962 & 3.685 & 51.197 & 2.020 & 1.488 & 1.059 & $\$ \mathrm{M}$ \\
\hline Operating \& Maintenance Costs (2010 \$M/year) & & 59.474 & 66.335 & 62.418 & 152.744 & 142.215 & 1947.696 & 78.941 & 58.736 & 42.460 & \$M/year \\
\hline Estimated Cost of & & & & & & rid Power & eration Option & & & & \\
\hline RPSEA Concept of Operations Site: Argonauta & & PWR & $\mathrm{FC1}$ & $\mathrm{FC2}$ & svi & SV2 & SV3 & PWR TEG & WELL TEG & GRID & Units \\
\hline Electric Power Generation & & 2.2000 & 2.2000 & 2.2000 & 2.2000 & 2.2000 & 2.2000 & 2.2000 & 2.2000 & 2.2000 & MW-e \\
\hline Hours Per Year & & 8766 & 8766 & 8766 & 8766 & 8766 & 8766 & 8766 & 8766 & 8766 & hours/year \\
\hline Annual Electric & & $929 \mathrm{E}+07$ & $929 \mathrm{E}+07$ & $929 \mathrm{E}+07$ & $29 \mathrm{E}+07$ & $229 \mathrm{E}+07$ & $1.929 E+07$ & $1.929 \mathrm{E}+07$ & $1.929 \mathrm{E}+07$ & $.929 \mathrm{E}+07$ & kWh-e/year \\
\hline & & $2.102 E+08$ & $2.351 \mathrm{E}+08$ & $2.209 E+08$ & $5.489 \mathrm{E}+08$ & $5.107 \mathrm{E}+08$ & $7.067 E+09$ & $2.809 \mathrm{E}+08$ & $2.075 \mathrm{E}+08$ & $1.484 \mathrm{E}+08$ & $\$ /$ year \\
\hline Cost of Electricity (COE) & & $1.090 \mathrm{E}+01$ & $1.219 \mathrm{E}+01$ & $1.145 E+01$ & $2.846 \mathrm{E}+01$ & $2.648 \mathrm{E}+01$ & $3.665 E+02$ & $1.457 \mathrm{E}+01$ & $1.076 \mathrm{E}+01$ & $7.695 \mathrm{E}+00$ & $\$ / k W h-\mathrm{e}$ \\
\hline
\end{tabular}


Table I 7 - Summary of the detailed economic analysis performed for the Marimba Field site

\begin{tabular}{|c|c|c|c|c|c|c|c|c|c|c|c|}
\hline Assumptions & Value & Units & \multicolumn{3}{|l|}{ Reference } & \multirow{2}{*}{$\begin{array}{l}\text { Nomenclature } \\
\text { PWR }\end{array}$} & \\
\hline Required Power & 0.0800 & MW-e & \multirow{2}{*}{\multicolumn{3}{|c|}{$\begin{array}{l}\text { esite Dependent } \\
\text { SAnalyst Estimate }\end{array}$}} & & \multicolumn{4}{|c|}{$\begin{array}{l}\text { Description of Deep Ocean Hybrid System } \\
\text { WR }=\text { Nuclear Reactor }+\mathrm{Pb} \text { Acid Battery }\end{array}$} & \\
\hline Service Life $=\mathrm{n}$ & 15 & years & & & & \multicolumn{6}{|c|}{$\begin{array}{l}\text { PWR } P W R=\text { Nuclear Reactor }+ \text { Pb Acid Battery } \\
\text { FC1 } F C 1=\text { Line for Surface O2 }+ \text { WELL Head Gas }+ \text { Reformer }+ \text { PEMFC + Battery }\end{array}$} \\
\hline Interest Rate $=\mathrm{i}$ & 5 & $\%$ & \multicolumn{3}{|l|}{ Analyst Estimate } & \multicolumn{6}{|c|}{$\begin{array}{l}\text { FC1 } F C 1=\text { Line for Surface O2 + WELL Head Gas + Reformer + PEMFC + Battery } \\
\text { FC2 }\end{array}$} \\
\hline Compound Interest Factor $=f_{i}=(1+i)^{n}$ & 2.0789 & factor & \multicolumn{3}{|c|}{ Perry's 7th Edition pp. 9-10 to 9-13 } & svi & \multicolumn{5}{|c|}{ SV1 = Submersible Vehicle + Stored O2 + Fuel Cell + Battery } \\
\hline Discount Factor $=f_{d}=1 / f$ & 0.4810 & factor & \multicolumn{3}{|c|}{ Perry's 7th Edition pp. 9-10 to 9-13 } & $\mathrm{sv}_{2}$ & \multicolumn{5}{|c|}{ SV2 $=$ Submersible Vehicle + Stored O2 + Engine or Turbine + Battery } \\
\hline Annuity Future Worth Factor $=f_{A F}=A / F=i /\left[(1+i)^{n}-1\right]$ & 0.0463 & factor & \multirow{2}{*}{\multicolumn{3}{|c|}{ Perry's 7th Edition pp. 9-10 to 9-13 }} & sv3 & \multicolumn{5}{|c|}{ SV3 $=$ Submersible Vehicle + Charge at Docking Station + ZEBRA Battery } \\
\hline Annuity Present Worth Factor $\left.=f_{A P}=A / P=\left[(1+i)^{n}\right] /(1+i) n-1\right]$ & 0.0963 & factor & & & & PWR TEG & PWR TEG $=$ PW & R + WELL TEG & b Acid Batter & & \\
\hline Salary \& Fringe Benefits - Management & 300000 & $\$ /$ year & Analyst Estimate & & & WELL TEG & WELL TEG $=$ Th & imoelectric Gen & tor + Well $\mathrm{He}$ & Waste Heat + & + Battery \\
\hline Salary \& Fringe Benefits - Engineer & 200000 & \$/year & Analyst Estimate & & & GRID & GRID $=$ Floor Ele & ctrical Grid + Bat & & & \\
\hline Salary \& Fringe Benefits - Operations & 100000 & $\$ / y e a r$ & Analyst Estimate & & & DOC & DOC $=$ Deep Oce & an Current + Bat & & & \\
\hline Investment at Comencement of Commercial Operations & & & & & & lybrid Power Gt & eneration Optio & & & & \\
\hline RPSEA Concept of Operations Site: Marimba Field & Factor & PWR & FC1 & $\mathrm{FC2}$ & SV1 & SV2 & SV3 3 & PWR TEG & WELLL TEG & GRID & Units \\
\hline Energy Conversion \& Storage & & 0.653 & 1.192 & 0.933 & 2.331 & 0.618 & 7392 & 0813 & 0.213 & 32.83 & \\
\hline Oxygen Supply & & 0.000 & 2.592 & 0.002 & 0.004 & 0.003 & 0.000 & 0.000 & 0.000 & 0.000 & $\$ \mathrm{M}$ \\
\hline \begin{tabular}{|l|} 
Pressure Vessels \\
\end{tabular} & & 450.063 & 450.158 & 450.136 & 1125.341 & 1125.143 & 15752.790 & 600.249 & 450.246 & 300.059 & $\$ \mathrm{M}$ \\
\hline Flotation Tanks & & 450.147 & 450.188 & 450.217 & 1125.541 & 1125.450 & 15754.847 & 600.256 & 450.246 & 300.137 & $\$ \mathrm{M}$ \\
\hline Miscellaneous & & 0.000 & 0.000 & 0.000 & 0.000 & 0.000 & 0.000 & 0.000 & 0.000 & 0.000 & $\$ \mathrm{M}$ \\
\hline Direct Costs Subtotal (2010 \$M) & & 900.862 & 904.130 & 901.287 & 2253.218 & 2251.214 & 31515.029 & 1201.318 & 900.705 & 633.000 & $\$ \mathrm{M}$ \\
\hline & & & & & & & & & & & \\
\hline Construction Services & 0.1 & 90.086 & 90.413 & 90.129 & 225.322 & 225.121 & 3151.503 & 120.132 & 90.070 & 63.300 & $\$ \mathrm{M}$ \\
\hline Home Office Engineering \& Services & 0.07 & 63.060 & 63.289 & 63.090 & 157.725 & 157.585 & 2206.052 & 84.092 & 63.049 & 44.310 & $\$ \mathrm{M}$ \\
\hline Field Office Engineering \& Services & 0.05 & 45.043 & 45.206 & 45.064 & 112.661 & 112.561 & 1575.751 & 60.066 & 45.035 & 31.650 & $\$ \mathrm{M}$ \\
\hline Owner's Costs & 0.13 & 117.112 & 117.537 & 117.167 & 292.918 & 292.658 & 4096.954 & 156.171 & 117.092 & 82.290 & $\$ \mathrm{M}$ \\
\hline Licensing \& Permitting & 0.01 & 30.009 & 9.041 & 9.013 & 22.532 & 22.512 & 315.150 & 33.013 & 9.007 & 6.330 & $\$ \mathrm{M}$ \\
\hline Indirect Costs Subtotal (2010 \$M) & & 345.310 & 325.487 & $\begin{array}{l}324.463 \\
\end{array}$ & 811.158 & 810.437 & 11345.411 & 453.474 & 324.254 & 227.880 & $\$ M$ \\
\hline Total \& Indirect Costs (2010 \$M) & & 1246.173 & $\mid 1229.617$ & 1225.751 & 3064.377 & 3061.651 & 42860.440 & 1654.792 & 1224.959 & 860.880 & $\$ M$ \\
\hline & & & & & & & & & & & \\
\hline Contingency Allowancy & 0.10 & 124.617 & 122.962 & 122.575 & 306.438 & 306.165 & 4286.044 & 165.479 & 122.496 & 86.088 & $\$ \mathrm{M}$ \\
\hline \begin{tabular}{|l|} 
Miscellaneous \\
\end{tabular} & 0.01 & 12.462 & 12.296 & 12.258 & 30.644 & 30.617 & 428.604 & 16.548 & 12.250 & 8.609 & $\$ \mathrm{M}$ \\
\hline Total Overnight Costs & & 1383.252 & 1364.874 & 1360.583 & 3401.458 & 3398.433 & 47575.088 & 1836.819 & 1359.704 & 955.576 & $\$ \mathrm{M}$ \\
\hline & & & & & & & & & & & \\
\hline Allowance for Escalation During Construction & 0.05 & 69.163 & 68.244 & 68.029 & 170.073 & 169.922 & 2378.754 & 91.841 & 67.985 & 47.779 & $\$ \mathrm{M}$ \\
\hline Allowance for Interest & 0.05 & 69.163 & 68.244 & 68.029 & 170.073 & 169.922 & 2378.754 & 91.841 & 67.985 & 47.779 & $\$ \mathrm{M}$ \\
\hline Capital Investment at Commercial Operation $(2010 \$ M)$ & & 1521.577 & 1501.362 & 1496.641 & 3741.604 & 3738.276 & 52332.597 & 2020.501 & 1495.675 & 1051.134 & $\$ \mathrm{M}$ \\
\hline Annualized Investment at Commercial Operation (2010 \$M/year) & 0.0963 & 146.592 & 144.645 & 144.190 & 360.475 & 360.154 & 5041.842 & 194.660 & 144.097 & 101.269 & \$M \\
\hline & & & & & & & & & & & \\
\hline Operating \& Maintenance Costs & & & & & & Power G & eneration Optio & & & & \\
\hline RPSEA Concept of Operations Site: Marimba Field & FTE & PWR & FC1 & $\mathrm{FC2}$ & SV1 & SV2 & SV3 & PWR TEG & WELL TEG & GRID & Units \\
\hline Managers & 2 & 600000 & 600000 & 600000 & 600000 & 600000 & 600000 & & 600000 & 600000 & \$/year \\
\hline Engineers & 4 & 800000 & 800000 & 800000 & 800000 & 800000 & 800000 & 800000 & 800000 & 800000 & \$/year \\
\hline Operators & 8 & 800000 & 800000 & 800000 & 800000 & 800000 & 800000 & 800000 & 800000 & 800000 & $\$ /$ year \\
\hline RPSEA Concept of Operations Site: Marimba Field & Factor & PWR & FC1 & $\mathrm{FC2}$ & SV1 & SV2 & SV3 & PWR TEG & WELL TEG & GRID & Units \\
\hline Salaries \& Benefits & & 2.200 & 2.200 & 2.200 & 2.200 & 2.200 & 2.200 & 2.200 & 2.200 & 2.200 & $\$ \mathrm{M}$ \\
\hline Chemicals, Materials \& Utilities & 0.10 & 14.659 & 14.464 & 14.419 & 36.047 & 36.015 & 504.184 & 19.466 & 14.410 & 10.127 & $\$ \mathrm{M}$ \\
\hline Spare Parts \& Capital Plant Upgrades & 0.10 & 14.659 & 14.464 & 14.419 & 36.047 & 36.015 & 504.184 & 19.466 & 14.410 & 10.127 & $\$ \mathrm{M}$ \\
\hline Taxes \& Insurance & 0.10 & 14.659 & 14.464 & 14.419 & 36.047 & 36.015 & 504.184 & 19.466 & 14.410 & 10.127 & $\$ \mathrm{M}$ \\
\hline Operating Cost Contingency & 0.05 & 7.330 & 7.232 & 7.209 & 18.024 & 18.008 & 252.092 & 9.733 & 7.205 & 5.063 & $\$ \mathrm{M}$ \\
\hline General O\&M & 0.02 & 2.932 & 2.893 & 2.884 & 7.209 & 7.203 & 100.837 & 3.893 & 2.882 & 2.025 & $\$ \mathrm{M}$ \\
\hline Miscellaneous & 0.01 & 1.466 & 1.446 & 1.442 & 3.605 & 3.602 & & 1.947 & 1.441 & 1.013 & $\$ \mathrm{M}$ \\
\hline Operating \& Maintenance Costs (2010 \$M/year) & & 57.905 & 57.165 & 56.992 & 139.180 & 139.059 & 1918.100 & 76.171 & 56.957 & 40.682 & $\$ M /$ year \\
\hline Estimated Cost of Electricity & & & & & & ower G: & ration Optio & & & & \\
\hline of Operations Site: Marimba Field & & PWR & $\mathrm{FCl}$ & $\mathrm{FC2}$ & SV1 & SV2 & SV3 & PWR TEG & WELL TEG & GRID & Units \\
\hline Generation & & 0.0800 & 0.0800 & 0.0800 & 0.0800 & 0.0800 & 0.0800 & 0.0800 & 0.0800 & 0.0800 & MW-e \\
\hline Hours Per Year & & 8766 & 8766 & 8766 & 8766 & 8766 & 8766 & 8766 & 8766 & 8766 & hours/year \\
\hline ergy Production & & $7.013 \mathrm{E}+05$ & $7.013 \mathrm{E}+05$ & $7.013 \mathrm{E}+05$ & $7.013 \mathrm{E}+05$ & $7.013 \mathrm{E}+05$ & $7.013 E+05$ & $7.013 E+05$ & $7.013 \mathrm{E}+05$ & $7.013 \mathrm{E}+05$ & kWh-e/year \\
\hline Annual Production Cost & & $2.045 \mathrm{E}+08$ & $2.018 \mathrm{E}+08$ & $2.012 \mathrm{E}+08$ & $4.997 \mathrm{E}+08$ & $4.992 \mathrm{E}+08$ & $6.960 \mathrm{E}+09$ & $2.708 \mathrm{E}+08$ & $2.011 \mathrm{E}+08$ & $1.420 \mathrm{E}+08$ & \$/year \\
\hline Cost of Electricity (COE) & & $2.916 \mathrm{E}+02$ & $2.878 E+02$ & $2.869 \mathrm{E}+02$ & $7.125 \mathrm{E}+02$ & $7.119 \mathrm{E}+02$ & $9.925 \mathrm{E}+03$ & $3.862 E+02$ & $2.867 \mathrm{E}+02$ & $2.024 \mathrm{E}+02$ & $\$ / k W h-e$ \\
\hline
\end{tabular}


Table I 8 - Summary of the detailed economic analysis performed for the Pazflor site

\begin{tabular}{|c|c|c|c|c|c|c|c|c|c|c|c|}
\hline Assumptions & Value & \multicolumn{4}{|c|}{ Units Reference } & Nomenclature & \multicolumn{5}{|c|}{ Description of Deep Ocean Hybrid System } \\
\hline Required Power & 13.8000 & \multirow{2}{*}{\multicolumn{4}{|c|}{$\begin{array}{l}\text { MW-e } \\
\text { years }\end{array}$}} & PWR & \multicolumn{5}{|c|}{ PWR $=$ Nuclear Reactor + Pb Acid Battery } \\
\hline Service Life $=\mathrm{n}$ & 15 & & & & & FC1 & \multicolumn{5}{|c|}{ FC1 = Line for Surface O2 + WELL Head Gas + Reformer + PEMFC + Battery } \\
\hline Interest Rate $=\mathrm{i}$ & 5 & \multicolumn{4}{|c|}{ \% Analyst Estimate } & $\mathrm{FC}_{2}$ & \multicolumn{5}{|c|}{ FC2 $=$ Stored $\mathrm{O} 2+$ Well Head Gas + Reformer + Fuel Cell + Battery } \\
\hline Compound Interest Factor $=f_{i}=(1+i)^{n}$ & 2.0789 & \multicolumn{4}{|c|}{ factor Perry's 7th Edition pp. 9-10 to 9-13 } & svi & \multicolumn{5}{|c|}{ SV1 = Submersible Vehicle + Stored O2 + Fuel Cell + Battery } \\
\hline Discount Factor $=f_{d}=1 / f i$ & 0.4810 & factor $\mathrm{P}$ & \multicolumn{3}{|c|}{ Perry's 7th Edition pp. 9-10 to 9-13 } & sve & \multicolumn{5}{|c|}{ SV2 $=$ Submersible Vehicle + Stored O2 + Engine or Turbine + Battery } \\
\hline Annuity Future Worth Factor $=f_{A F}=A / F=i /\left[(1+i)^{n}-1\right]$ & 0.0463 & factor $\mathrm{P}$ & \multicolumn{3}{|c|}{ Perry's 7th Edition pp. 9-10 to 9-13 } & SV3 & \multicolumn{5}{|c|}{ SV3 = Submersible Vehicle + Charge at Docking Station + ZEBRA Battery } \\
\hline Annuity Present Worth Factor $=f_{A P}=A / P=\left[(1+i)^{n} y /(1+i) n-1\right]$ & 0.0963 & factor $\mathrm{P}$ & \multicolumn{3}{|c|}{ Perry's 7th Edition pp. 9-10 to 9-13 } & PWR TEG & \multicolumn{5}{|c|}{ PWR TEG = PWR + WELL TEG + Pb Acid Battery } \\
\hline Salary \& Fringe Benefits - Management & 300000 & $\$ /$ year $A$ & Analyst Estimate & & & WELL TEG & WELL TEG $=$ The & noelectric Gen & ator + Well Hea & Waste Heat + & Battery \\
\hline Salary \& Fringe Beneffits - Engineer & 200000 & $\$ /$ year $A$ & Analyst Estimate & & & GRID & GRID $=$ Floor Ele & ical Grid $+\mathrm{Ba}$ & & & \\
\hline Salary \& Fringe Benefits - Operations & 100000 & $\$ /$ year/A & Analyst Estimate & & & DOC & DOC $=$ Deep Oce & Current $+\mathrm{Ba}$ & & & \\
\hline Investment at Comencement of Commercial Operations & & & & & & ybrid Power $\mathrm{Ge}_{\mathrm{e}}$ & eneration Optior & & & & \\
\hline RPSEA Concept of Operations Site: Pazflor & Factor & PWR & FC1 & FC2 & SV1 & SV2 & \begin{tabular}{|r|r|} 
SV 3 \\
\end{tabular} & PWR TEG & WELL TEG & GRID & Units \\
\hline & & & & & & & & & & & \\
\hline Energy Conversion \& Storage & & 112.608 & 279.154 & 195.636 & 489.090 & 111.815 & 1275.120 & 140.208 & 36.708 & 49.108 & $\$ M$ \\
\hline Oxygen Supply & & 0.000 & 5.250 & 0.401 & 1.003 & 0.789 & 0.000 & 0.000 & 0.000 & 0.000 & $\$ M$ \\
\hline \begin{tabular}{|l|} 
Pressure Vessels \\
\end{tabular} & & 454.405 & 465.809 & 462.049 & 1155.122 & 1134.319 & 15931.707 & 620.969 & 470.784 & 304.221 & $\$ M$ \\
\hline Flotation Tanks & & 461.746 & 469.359 & 471.832 & 1179.580 & 1162.088 & 16089.689 & 621.816 & 471.290 & 311.220 & $\$ M$ \\
\hline Miscellaneous & & 0.000 & 0.000 & 0.000 & 0.000 & 0.000 & 0.000 & 0.000 & 0.000 & 0.000 & $\$ M$ \\
\hline Direct Costs Subtotal $(2010 \$ \mathrm{M})$ & & \begin{tabular}{ll|}
1028.759 \\
\end{tabular} & \begin{tabular}{|l|}
1219.571 \\
\end{tabular} & 1129.919 & \begin{tabular}{ll|}
2824.797 \\
\end{tabular} & 2409.012 & 33296.516 & $\begin{array}{ll}1382.993 \\
\end{array}$ & $\begin{array}{l}978.782 \\
\end{array}$ & 664.549 & $\$ M$ \\
\hline Construction Services & 0.1 & 102.876 & 121.957 & 112.992 & 282.480 & 240.901 & 3329.652 & 138.299 & \begin{tabular}{l|l}
97.878 \\
\end{tabular} & 66.455 & $\$ M$ \\
\hline Home Office Engineering \& Services & 0.07 & 72.013 & 85.370 & 79.094 & 197.736 & 168.631 & 2330.756 & 96.809 & 68.515 & 46.518 & $\$ \mathrm{M}$ \\
\hline Field Office Engineering \& Services & 0.05 & 51.438 & 60.979 & 56.496 & 141.240 & 120.451 & 1664.826 & 69.150 & 48.939 & 33.227 & $\$ M$ \\
\hline Owner's Costs & 0.13 & 133.739 & 158.544 & 146.889 & 367.224 & 313.171 & 4328.547 & 179.789 & 127.242 & 86.391 & $\$ M$ \\
\hline Licensing \& Permitting & 0.01 & 31.288 & 12.196 & 11.299 & 28.248 & 24.090 & 332.965 & 34.830 & 9.788 & 6.645 & $\$ M$ \\
\hline Indirect Costs Subtotal (2010 \$M) & & 391.353 & 439.046 & 406.771 & 1016.927 & 867.244 & \begin{tabular}{ll|l}
11986.746 \\
\end{tabular} & 518.877 & 352.362 & 239.238 & \$M \\
\hline Total \& Indirect Costs (2010 \$M) & & \begin{tabular}{|c|c|c|}
1420.113 \\
\end{tabular} & 1658.617 & 1536.689 & 3841.723 & 3276.256 & 45283.262 & 1901.870 & 1331.144 & 903.786 & \$M \\
\hline & & & & & & & & & & & \\
\hline Contingency Allowancy & 0.10 & 142.011 & 165.862 & 153.669 & 384.172 & 327.626 & 4528.326 & 190.187 & 133.114 & 90.379 & $\$ \mathrm{M}$ \\
\hline Miscellaneous & 0.01 & 14.201 & 16.586 & 15.367 & 38.417 & 32.763 & 452.833 & 19.019 & 13.311 & 9.038 & $\$ M$ \\
\hline Total Overnight Costs & & 1576.325 & 1841.065 & 1705.725 & 4264.313 & 3636.644 & 50264.420 & 2111.076 & 1477.570 & 1003.203 & $\$ M$ \\
\hline & & & & & & & & & & & \\
\hline Allowance for Escalation During Construction & 0.05 & 78.816 & 92.053 & 85.286 & 213.216 & 181.832 & 2513.221 & 105.554 & 73.878 & 50.160 & $\$ \mathrm{M}$ \\
\hline Allowance for Interest & 0.05 & 78.816 & 92.053 & 85.286 & 213.216 & 181.832 & 2513.221 & 105.554 & 73.878 & 50.160 & $\$ \mathrm{M}$ \\
\hline Capital Investment at Commercial Operation $(2010 \$ M)$ & & 1733.957 & 2025.171 & 1876.298 & 4690.744 & 4000.308 & 55290.862 & 2322.183 & 1625.327 & 1103.523 & $\$ M$ \\
\hline Annualized Investment at Commercial Operation (2010 \$M/year) & 0.0963 & 167.053 & 195.110 & 180.767 & 451.917 & 385.399 & 5326.848 & 223.724 & 156.588 & 106.316 & \$M \\
\hline & & & & & & & & & & & \\
\hline $\begin{array}{l}\text { Operating \& Maintenance Costs } \\
\text { RPSEA Concent of Onerafions Site. Parth }\end{array}$ & & & & & & $\begin{array}{ll}\text { olwer Ge } \\
\text { SVI }\end{array}$ & fation Optior & & & & \\
\hline $\begin{array}{l}\text { RPSEA Concept of Operations Site: Pazilor } \\
\text { Managers }\end{array}$ & FTE & PWR & FC1 & $\mathrm{FC2}$ & SVI & S SV 2 & \begin{tabular}{r|r}
$\mathrm{SV} 3$ \\
600000
\end{tabular} & 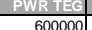 & IELL TEC & $\frac{\text { GRID }}{60000}$ & $\begin{array}{l}\text { Units } \\
\text { S/year }\end{array}$ \\
\hline \begin{tabular}{|l|} 
Managers \\
Engineers \\
\end{tabular} & 2 & $\begin{array}{ll}600000 \\
800000\end{array}$ & $\begin{array}{l}600000 \\
800000 \\
\end{array}$ & $\begin{array}{ll}600000 \\
800000 \\
\end{array}$ & $\frac{600000}{800000}$ & $\begin{array}{ll}600000 \\
800000 \\
\end{array}$ & $\begin{array}{l}600000 \\
800000 \\
\end{array}$ & $\begin{aligned} 600000 \\
800000 \\
\end{aligned}$ & $\begin{array}{ll}600000 \\
800000\end{array}$ & $\begin{array}{ll}600000 \\
800000\end{array}$ & \$/year \\
\hline \begin{tabular}{|l|l|l|l|l} 
Operators \\
\end{tabular} & & 800000 & 800000 & 800000 & 800000 & 800000 & 800000 & 800000 & 800000 & 800000 & \$/year \\
\hline RPSEA Concept of Operations Site: Pazillor & Factor & PWR & FC1 & $\mathrm{FC}_{2}$ & SV1 & SV2 & SV3 & PWR TEG & WELL TEG & GRID & Units \\
\hline Salaries \& Benefits & & 2.200 & 2.200 & 2.200 & 2.200 & 2.200 & 2.200 & 2.200 & 2.200 & 2.200 & $\$ M$ \\
\hline Chemicals, Materials \& Utilities & 0.10 & 16.705 & 19.511 & 18.077 & 45.192 & 38.540 & 532.685 & 22.372 & 15.659 & 10.632 & $\$ M$ \\
\hline Spare Parts \& Capital Plant Upgrades & 0.10 & 16.705 & 19.511 & 18.077 & 45.192 & 38.540 & 532.685 & 22.372 & 15.659 & 10.632 & $\$ M$ \\
\hline Taxes \& Insurance & 0.10 & 16.705 & 19.511 & 18.077 & 45.192 & 38.540 & 532.685 & 22.372 & 15.659 & 10.632 & $\$ \mathrm{M}$ \\
\hline Operating Cost Contingency & 0.05 & 8.353 & 9.755 & 9.038 & 22.596 & 19.270 & 266.342 & 11.186 & 7.829 & 5.316 & $\$ \mathrm{M}$ \\
\hline General O\&M & 0.02 & 3.341 & 3.902 & 3.615 & 9.038 & 7.708 & 106.537 & 4.474 & 3.132 & 2.126 & $\$ M$ \\
\hline Miscellaneous & 0.01 & 1.671 & 1.951 & 1.808 & 4.519 & 3.854 & 53.268 & 2.237 & 1.566 & 1.063 & $\$ \mathrm{M}$ \\
\hline Operating \& Maintenance Costs (2010 \$M/year) & & 65.680 & 76.342 & 70.891 & 173.928 & 148.652 & 2026.402 & 87.215 & \begin{tabular}{l|l|l|l}
61.703 \\
\end{tabular} & 42.600 & \$M/year \\
\hline Estimat & & & & & & Power Ge & ration Optior & & & & \\
\hline RPSEA Concept of Operations Site: Pazilor & & PWR & $\mathrm{FC} 1$ & $\mathrm{FC2}$ & SV1 & SV2 & SV3 & PWR TEG & WELL TEG & GRID & Units \\
\hline Electric Power Generation & & 13.8000 & 13.8000 & 13.8000 & 13.8000 & 13.8000 & 13.8000 & 13.8000 & 13.8000 & 13.8000 & MW-e \\
\hline Hours Pe & & 8766 & 8766 & 8766 & 8766 & 8766 & & 87 & 8766 & 8766 & hours/year \\
\hline Annual Electric Energy Production & & $1.210 \mathrm{E}+08$ & $1.210 \mathrm{E}+08$ & $1.210 E+08$ & $1.210 \mathrm{E}+08$ & $1.210 \mathrm{E}+08$ & $1.210 \mathrm{E}+08$ & $1.210 E+08$ & $1.210 \mathrm{E}+08$ & $1.210 E+08$ & kWh-e/year \\
\hline Annual Production Cost & & $2.327 \mathrm{E}+08$ & $2.715 \mathrm{E}+08$ & $2.517 \mathrm{E}+08$ & $6.258 \mathrm{E}+08$ & $5.341 \mathrm{E}+08$ & $7.353 \mathrm{E}+09$ & $3.109 \mathrm{E}+08$ & $2.183 \mathrm{E}+08$ & $1.489 \mathrm{E}+08$ & \$/year \\
\hline Cost of Electricity (COE) & & $1.924 \mathrm{E}+00$ & $2.244 \mathrm{E}+00$ & $2.080 E+00$ & $5.174 \mathrm{E}+00$ & $4.415 E+00$ & $6.079 \mathrm{E}+01$ & $2.570 \mathrm{E}+00$ & $1.804 \mathrm{E}+00$ & $1.231 E+00$ & $\$ /$ kWh-e \\
\hline
\end{tabular}

